\title{
Characterization Activities to Evaluate Chlorinated Solvent Discharges to Tims Branch from the A/M Area of the Savannah River Site (U).
}

November 15, 2000

Dennis G. Jackson Jay V. Noonkester Karen M. Vangelas

Robin L. Brigmon

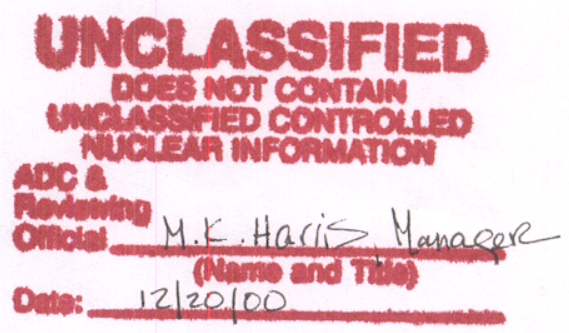

Westinghouse Savannah River Company Savannah River Site

Aiken, South Carolina 29808

Prepared for the United States Department of Energy under Contract No. DE-AC09-96SR18500. 
This document was prepared in conjunction with work accomplished under Contract No.

DE-AC09-96SR18500 with the U.S. Department of Energy.

\section{DISCLAIMER}

This report was prepared as an account of work sponsored by an agency of the United States Government. Neither the United States Government nor any agency thereof, nor any of their employees, makes any warranty, express or implied, or assumes any legal liability or responsibility for the accuracy, completeness, or usefulness of any information, apparatus, product or process disclosed, or represents that its use would not infringe privately owned rights. Reference herein to any specific commercial product, process or service by trade name, trademark, manufacturer, or otherwise does not necessarily constitute or imply its endorsement, recommendation, or favoring by the United States Government or any agency

thereof. The views and opinions of authors expressed herein do not necessarily state or reflect those of the United States Government or any agency thereof.

This report has been reproduced directly from the best available copy.

Available for sale to the public, in paper, from: U.S. Department of Commerce, National Technical Information Service, 5285 Port Royal Road, Springfield, VA 22161, phone: (800)

553-6847, fax: (703) 605-6900, email: orders@ntis.fedworld.gov online ordering: http://www.ntis.gov/ordering.htm

Available electronically at http://www.doe.gov/bridge

Available for a processing fee to U.S. Department of Energy and its contractors, in paper, from: U.S. Department of Energy, Office of Scientific and Technical Information, P.O. Box 62, Oak Ridge, TN 37831-0062, phone: (865 ) 576-8401, fax: (865) 576-5728, email: reports@ adonis.osti.gov 


\section{Characterization Activities to Evaluate Chlorinated Solvent Discharges to Tims Branch from the A/M Area of the Savannah River Site (U).}

November 15, 2000

Dennis G. Jackson Jay V. Noonkester

Karen M. Vangelas

Robin L. Brigmon

Environmental Sciences \& Technology Department

Savannah River Technology Center

Prepared By:

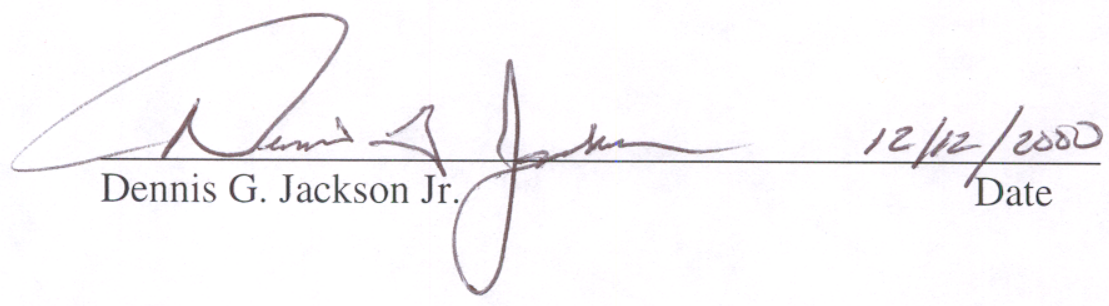

Westinghouse Savannah River Company

Savannah River Site

Aiken, South Carolina 29808

Prepared for the United States Department of Energy under Contract No.DE-AC09-96SR18500 


\section{Executive Summary:}

Natural and sustainable remediation concepts are the preferred alternatives for distal lowconcentration portions of contaminant plumes. In A/M Area we are investigating the potential for implementing such techniques in combination with source zone treatments in higher concentration areas. Identifying the probable location of future plume discharges, magnitudes, and structure in the distal fringe are critical to the implementation and performance of natural attenuation based systems. The early installation of long-term monitoring systems in these projected discharge zones is an important component to providing baseline data necessary for remedial assessment.

In this investigation the distal portion of the large chlorinated solvent plume associated with historical releases in the A/M Area, specifically those associated with the M-Area Settling Basin and with the A-014 Outfall, were examined. Within this plume the primary compounds of interest are the volatile organic contaminants (VOCs) trichloroethylene (TCE) and tetrachloroethylene (PCE). Phytoremediation has been proposed for that portion of the groundwater seepline that will be impacted by this plume's discharge. The potential success of phytoremediation is based on a combination of several parameters. These include hydrogeologic information associated with coastal plain geomorphic processes and the location of hydrologic boundaries along with three-dimensional aspects of groundwater flow in the vicinity of the seepline. In this study these concepts were integrated and used to direct seepline specific characterization activities. These results provided detailed information on the nature and distribution of contamination in the vicinity of the receptor stream, identified regions of potential plume outcrop, and established fixed monitoring points along the seepline to support long-term activities.

The characterization approach used was dynamic and graded. Initial efforts focused on the collection of large quantities of inexpensive data, followed by targeted minimally invasive drilling to collect depth-discrete sediment data, and concluded with the installation of permanent groundwater monitoring wells. The initial efforts involved the deployment of passive diffusion type samplers in the hyporheic zone of the receiving stream. This targeted flowlines that are considered to be associated with the VOC plume in the Southern Sector. The deployment locations were based on the hydrogeologic setting and geomorphic processes associated with the stream. This activity allowed the aggregate characterization of the entire reach of the stream using a cost-effective sampling technique. These results were used to direct drilling activities in the outcrop region where depth-discrete sediment samples were collected using vibracoring equipment. This approach has minimal surface impact compared to traditional drilling technologies. This makes the technology ideal for shallow characterization associated with outcrop regions. The depth-discrete data provided important information on the vertical structure of the plume and was used to direct the installation of permanent monitoring wells to support long-term monitoring needs.

Based on diffusion based sampling techniques, trichloroethylene and tetrachloroethylene is present in the hyporheic zone of Tims Branch near SRS Road 2. Coring activities accompanied with depth-discrete sediment analysis corroborates these results and suggests that the plume may be present in a well definable region south of SRS Road 2. Monitoring wells installed in this region confirmed the presence of trichloroethylene and tetrachloroethylene contamination near the northern extent of the study area. As interpreted by concentrations in monitoring wells, the 
plume has a nominal concentration level of $25 \mu \mathrm{g} / \mathrm{l}$ for trichloroethylene and $10 \mu \mathrm{g} / \mathrm{l}$ for tetrachloroethylene and a width considered to be on the order of 2000 feet.

Microbial populations determined from characterization near SRS Road 2 revealed the presence of a relatively diverse microbial community. This observation supports the potential for bioremediation activities along the seepline. In particular, the ratio of sulfate reducing bacteria to total community structure observed is a good indication of anaerobic dechlorination potential.

Characterization results also indicated that the plume might either extend or be located in a region towards the middle portion of the study area that has an expansive surface impoundment associated with beaver (Castor canadensis) habitat. This surface impoundment is considered to effect the discharge of groundwater in these vicinities. The effects on hydraulic head and resulting variations in plume location and migration related to this are uncertain and should be further investigated. Results from monitoring wells in this region did not indicate the presence of detectable levels of trichloroethylene or tetrachloroethylene. No significant levels of anaerobic degradation products were observed with samples associated with these characterization activities. Continued sampling and analysis of groundwater from the installed monitoring wells is necessary.

The groundwater component of the total stream flow in Tims Branch was determined from historical gaging information available from the USGS. Estimates of baseflow using hydrograph separation techniques estimate the average discharge in the vicinity of the outcrop is approximately 2.6 cubic feet of groundwater per second. This baseflow component was combined with initial sampling results from the installed wells near the stream to obtain an estimate of the mass flux approaching Tims Branch. Near stream attenuation processes such as biodegradation combined with dilution and volatilization are active attenuation process in the hyporheic zone. Thus, surface water concentrations in Tims Branch would be expected to be below those observed in the monitoring wells. Additional monitoring and characterization of stream baseflow, groundwater quality, and stream quality is recommended to formulate reliable predictions on the magnitude of this flux. The future collection of this data will be critical in evaluating the long-term performance of remediation activities that are associated with the seepline.

In this study the geological features of coastal plain outcrops were used with fundamentals of groundwater flow and contaminant transport to direct characterization to support phytoremediation efforts. By integrating the important aspects of geology and groundwater flow, investigators were able to effectively characterize the flux of contaminants entering the seepline and highlight the bioremediation potential. The work emphasizes the importance in understanding the role of plume geometry (vertical structure and flow trajectory) in the planning of natural attenuation based clean-up strategies. These baseline measurements and characterization approaches will be of significant benefit in assessing the long-term performance of the planned phytoremediation activities. 


\section{Table of Contents:}

EXECUTIVE SUMMARY: II

LIST OF FIGURES: V

LIST OF TABLES: VI

OBJECTIVE:

BACKGROUND: ......................................................................................................... 1

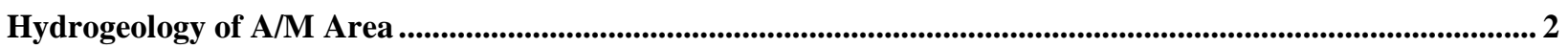

Contaminant Migration in the Southern Sector........................................................................................................ 3

Groundwater and Surface Water Interactions along Tims Branch ............................................................................5

APPROACH TO CHARACTERIZATION: _...........................................................10

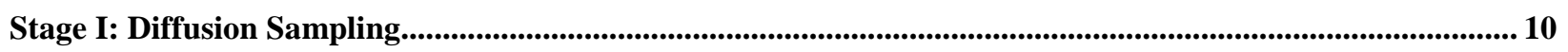

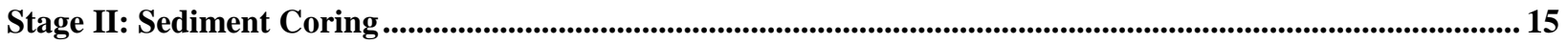

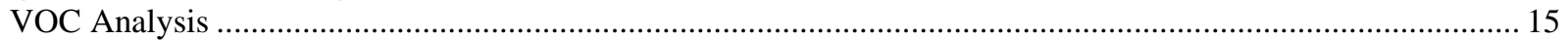

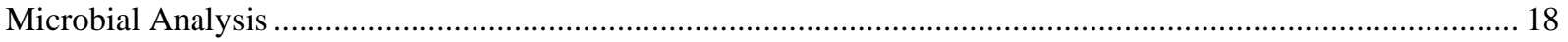

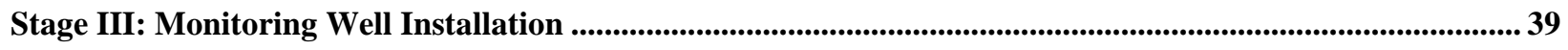

INTERPRETATION AND DISCUSSION: ..................................................45

CONCLUSIONS: ...............................................................................................47

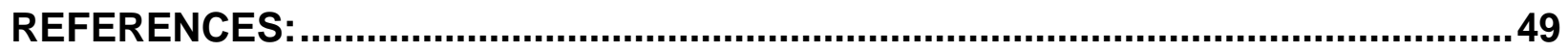

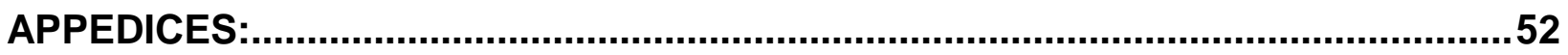

Hydrograph Separation Summary Tables for Station 02197306 and 02197309

Monitoring Well Construction and Installation Reports

Estimate of Mass-Flux to Hyporheic Zone Near Road 2 


\section{List of Figures:}

FIGURE 1: LOCATION OF TIMS BRANCH SEEPLINE STUDY AREA BETWEEN SRS ROAD 2 AND SRS ROAD C.....

FIGURE 2: STREAM HYDROGRAPHS FOR USGS GAGE STATIONS 02197306 AND 02197309 LOCATED

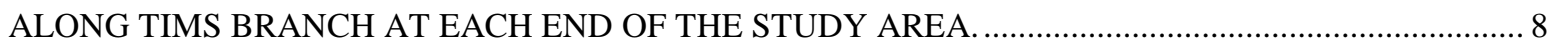

FIGURE 3: HYDROGRAPH SEPERATION RESULTS FOR USGS STREAM GAGE STATIONS ALONG TIMS BRANCH LOCATED ON EACH END OF THE STUDY AREA. ..................................................... 9

FIGURE 4: LOCATION OF DIFFUSION SAMPLERS DEPLOYED ALONG SEEPLINE BETWEEN SRS ROAD 2 AND SRS ROAD C.

FIGURE 5: LOCATION OF VIBRACORES THAT WERE COLLECTED ALONG SEEPLINE BETWEEN SRS

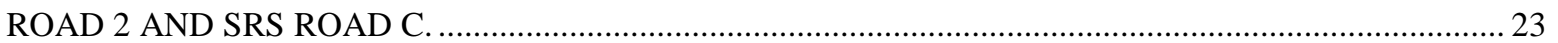

FIGURE 6: DEPTH-DISCRETE INTERPRETATION OF ANALYTICAL RESULTS FROM BORINGS SSL-12, SSL-13, SSL-14, AND SSL-15 INDICATING THE PRESENCE OF TRACE QUANTITIES OF TRICHLOROETHYLENE AND TETRACHLOROETHYLENE. ............................................................ 34

FIGURE 7: DEPTH-DISCRETE INTERPRETATION OF ANALYTICAL RESULTS FROM BORINGS SSL-17, SSL-18, SSL-22, AND SSL-32 INDICATING THE PRESENCE OF TRACE QUANTITIES OF TRICHLOROETHYLENE AND TETRACHLOROETHYLENE.......................................................... 35

FIGURE 8: TOTAL MICROBIAL DENSITIES (AODC) AND COLONY FORMING UNITS (CFU) FOR SSL-31 SEDIMENT SAMPLES COLLECTED ON AUGUST 14, 2000 ....................................................... 36

FIGURE 9: TOTAL MICROBIAL DENSITIES (AODC) AND COLONY FORMING UNITS (CFU) FOR SSL-32 SEDIMENT SAMPLES COLLECTED ON AUGUST 14, 2000 ....................................................... 36

FIGURE 10: LOCATION OF MONITORING WELLS THAT WERE INSTALLED ALONG THE SEEPLINE BETWEEN SRS ROAD 2 AND SRS ROAD C . ............................................................................... 43

FIGURE 11: SUMMARY OF DIFFUSION, VIBRACORE, AND MONITORING WELL SAMPLING RESULTS ALONG TIMS BRANCH SEEPLINE BETWEEN SRS ROAD 2 AND SRS ROAD C .............................. 48 
WSRC-TR-2000-00472

\section{List of Tables:}

TABLE 1: RESULTS FROM DIFFUSION SAMPLERS DEPLOYED ALONG SEEPLINE BETWEEN SRS

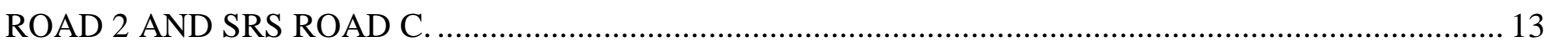

TABLE 2: SUMMARY OF VIBRACORING ALONG TIMS BRANCH IN SUPPORT OF SEEPLINE

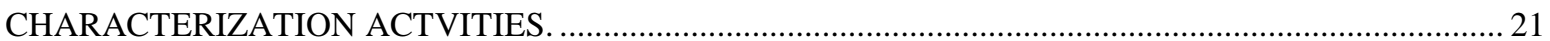

TABLE 3: DEPTH DISCRETE SOIL-PLUG CONCENTRATIONS ASSOCIATED WITH BORING SSL-12 COLLECTED ON JULY 6, 2000 ALONG TIMS BRANCH SEEPLINE.................................................. 24

TABLE 4: DEPTH DISCRETE SOIL-PLUG CONCENTRATIONS ASSOCIATED WITH BORING SSL-13 COLLECTED ON JULY 6, 2000 ALONG TIMS BRANCH SEEPLINE.

TABLE 5: DEPTH DISCRETE SOIL-PLUG CONCENTRATIONS ASSOCIATED WITH BORING SSL-14 COLLECTED ON JULY 6, 2000 ALONG TIMS BRANCH SEEPLINE ............................................. 25

TABLE 6: DEPTH DISCRETE SOIL-PLUG CONCENTRATIONS ASSOCIATED WITH BORING SSL-15

COLLECTED ON JULY 6, 2000 ALONG TIMS BRANCH SEEPLINE ............................................2 25

TABLE 7: DEPTH DISCRETE SOIL-PLUG CONCENTRATIONS ASSOCIATED WITH BORING SSL-16 COLLECTED ON JULY 7, 2000 ALONG TIMS BRANCH SEEPLINE.

TABLE 8: DEPTH DISCRETE SOIL-PLUG CONCENTRATIONS ASSOCIATED WITH BORING SSL-17

COLLECTED ON JULY 7, 2000 ALONG TIMS BRANCH SEEPLINE .............................................. 26

TABLE 9: DEPTH DISCRETE SOIL-PLUG CONCENTRATIONS ASSOCIATED WITH BORING SSL-18

COLLECTED ON JULY 7, 2000 ALONG TIMS BRANCH SEEPLINE. ............................................2 27

TABLE 10: DEPTH DISCRETE SOIL-PLUG CONCENTRATIONS ASSOCIATED WITH BORING SSL-20 COLLECTED ON JULY 10, 2000 ALONG TIMS BRANCH SEEPLINE. ...........................................2 27

TABLE 11: DEPTH DISCRETE SOIL-PLUG CONCENTRATIONS ASSOCIATED WITH BORING SSL-21 COLLECTED ON JULY 10, 2000 ALONG TIMS BRANCH SEEPLINE. ........................................2 28

TABLE 12: DEPTH DISCRETE SOIL-PLUG CONCENTRATIONS ASSOCIATED WITH BORING SSL-22 COLLECTED ON JULY 10, 2000 ALONG TIMS BRANCH SEEPLINE. ............................................ 28

TABLE 13: DEPTH DISCRETE SOIL-PLUG CONCENTRATIONS ASSOCIATED WITH BORING SSL-23 COLLECTED ON JULY 10, 2000 ALONG TIMS BRANCH SEEPLINE.

TABLE 14: $\quad$ DEPTH DISCRETE SOIL-PLUG CONCENTRATIONS ASSOCIATED WITH BORING SSL-24 COLLECTED ON JULY 10, 2000 ALONG TIMS BRANCH SEEPLINE .............................................. 29

TABLE 15: DEPTH DISCRETE SOIL-PLUG CONCENTRATIONS ASSOCIATED WITH BORING SSL-25 COLLECTED ON JULY 11, 2000 ALONG TIMS BRANCH SEEPLINE. .................................................. 30

TABLE 16: DEPTH DISCRETE SOIL-PLUG CONCENTRATIONS ASSOCIATED WITH BORING SSL-26 COLLECTED ON JULY 11, 2000 ALONG TIMS BRANCH SEEPLINE. ......................................... 30

TABLE 17: DEPTH DISCRETE SOIL-PLUG CONCENTRATIONS ASSOCIATED WITH BORING SSL-27 COLLECTED ON JULY 11, 2000 ALONG TIMS BRANCH SEEPLINE. ........................................... 31

TABLE 18: DEPTH DISCRETE SOIL-PLUG CONCENTRATIONS ASSOCIATED WITH BORING SSL-28 COLLECTED ON JULY 11, 2000 ALONG TIMS BRANCH SEEPLINE.......................................... 31

TABLE 19: DEPTH DISCRETE SOIL-PLUG CONCENTRATIONS ASSOCIATED WITH BORING SSL-29 COLLECTED ON JULY 12, 2000 ALONG TIMS BRANCH SEEPLINE.

TABLE 20: DEPTH DISCRETE SOIL-PLUG CONCENTRATIONS ASSOCIATED WITH BORING SSL-30 COLLECTED ON JULY 12, 2000 ALONG TIMS BRANCH SEEPLINE

TABLE 21: DEPTH DISCRETE SOIL-PLUG CONCENTRATIONS ASSOCIATED WITH BORING SSL-31 COLLECTED ON AUGUST 14, 2000 ALONG TIMS BRANCH SEEPLINE ......................................... 33

TABLE 22: DEPTH DISCRETE SOIL-PLUG CONCENTRATIONS ASSOCIATED WITH BORING SSL-32 COLLECTED ON AUGUST 14, 2000 ALONG TIMS BRANCH SEEPLINE............................................ 33

TABLE 23: SUMMARY OF PLFA RESULTS FOR SOUTHERN SECTOR SEEPLINE SEDIMENT SAMPLES FROM SSL-31 AND SSL-32.

TABLE 24: $\quad$ SUMMARY OF CONSTRUCTION INFORMATION FOR SEEPLINE MONITORING WELLS

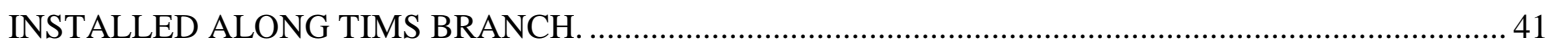

TABLE 25: ANALYTICAL RESULTS FROM INITIAL SAMPLING ACTIVITIES ASSOCIATED WITH SEEPLINE MONITORING WELLS ......................................................................................... 42 


\section{Objective:}

The objective of this investigation was to identify those regions of plume outcrop along Tims Branch southeast of A/M Area and to establish fixed monitoring points along the seepline to evaluate proposed remediation needs and to support long-term monitoring activities in the vicinity of the seepline. The characterization approach employed in completing these tasks was dynamic and graded. Three stages of characterization were used to evaluate the outcrop region, with the results from each of the previous activities used to direct subsequent characterization.

\section{Background:}

The A/M-Area is located in the northern section of the Savannah River Site (SRS) and consists of facilities that fabricated reactor fuel and target assemblies for the SRS reactors (M-Area), laboratory facilities (SRTC, formally SRL), and administrative and support facilities (A-Area). Operations at these and other facilities within the A/M Area have resulted in the release of chlorinated solvents, primarily trichloroethylene (TCE), tetrachloroethylene (PCE) and 1,1,1trichloroethane (1,1,1-TCA) to the subsurface (Marine and Bledose 1984). These releases have resulted in the contamination of the soil and groundwater within the area. Since the discovery of dissolved solvents within the groundwater beneath the A/M Area, SRS has pursued an aggressive path towards environmental remediation of the groundwater and subsurface contamination. Significant events and activities associated with this program include:

1) Installation and operation of an extensive groundwater recovery well network to treat contaminated groundwater;

2) Installation and operation of soil vapor extraction units for removal of contaminants in the vadose zone;

3) Identification of subsurface DNAPL along with the development and deployment of DNAPL specific characterization and remediation techniques;

4) Deployment of vertical recirculation wells to address regions of downgradient migration away from DNAPL source zones; and the

5) Evaluation and deployment of low-energy, self-sustainable technologies such as barometric pumping and phytoremediation to address low concentration, high volume portions of the vadose and saturated zones.

Each of the activities identified are associated with different portions of the contaminant plume within A/M Area, with each having different characteristics and needs. To assist with the management of the entire remediation program in the A/M Area, the region has been informally subdivided into five sectors. These sectors are the Central A/M Area, the Western Sector, the Southern Sector, the Northern Sector, and the Cretaceous. Although geographically and geologically identified, each of the sectors are defined based on the type of contaminants present, characterization tools employed, and the remediation approach(s) deployed. The delineation of the contaminant plume into sectors is primarily a management tool so that remediation strategies and goals for each sector can be appropriately developed.

This investigation focuses on the leading edge of the plume and is considered to be associated with groundwater contamination in the A/M Area. This portion of the contaminant plume is 
considered to have those characteristics associated with the "dilute fringe" as described by Looney (Looney 2000). The significant characteristics associated with this region are low concentrations, typically above regulatory or risk based criteria, that are dispersed throughout a large, vertically discrete volume of water. Cost effective remediation technologies in this region must rely on natural-sustainable-measurable processes. As reported by Looney this class of technology has recently gained regulatory support as "Monitored Natural Attenuation" processes. This remediation approach is biased towards the understanding of contaminant destruction and stabilization capabilities of native vegetation species and natural populations along with suitable measures of progress. Integral in this understanding is a complete and through knowledge of the contaminant distribution and the magnitude and rate of contaminant delivery to the natural remediation processes. A critical requirement for the success of these technologies is the development of logical and cost-effective, long-term monitoring strategies.

\section{Hydrogeology of A/M Area}

The hydrogeology in A/M Area consists of the three aquifers of the Floridan-Midville Aquifer System. Extensive hydrogeologic information on these units has been presented in previous characterization reports (Aadland et al. 1995) (Aadland et al. 1995) (Smits et al. 1998). The aquifers and separating confining units of the Floridan-Midville Aquifer System are comprised of inter-bedded layers of sands, silts, and clays that are typical of a shallow marine, deltaic depositional environment. Lithostratigraphically, these sediments range from Late Cretaceous to Recent in age and consist of layers of sand, muddy sand, and mud with subordinate calcareous sediments. The A/M Area lies near the up-dip limit of the coastal plain deposits, approximately 20 miles from the Fall Line. The aquifers present, in descending order, are the Steed Pond Aquifer, the Crouch Branch Aquifer, and the McQueen Branch Aquifer. The Steed Pond Aquifer is comprised of the regionally defined M-Area aquifer zone, the Green Clay confining zone, and the Lost Lake aquifer zone. The majority of the solvent contamination present in the A/M Area is located within the Steed Pond Aquifer. The Lost Lake aquifer zone is the primary target of current remediation programs within A/M Area and the projected outcrop regions of this aquifer zone are the focus of the current investigation.

As reported by the most recent characterization activities (Smits et al. 1998), the Lost Lake aquifer zone consists of yellow, tan, orange, and brown, loose to slightly indurated, fine to coarse, moderately to well-sorted, occasionally pebbly sand and minor clayey sand. The top of the Crouch Branch confining unit defines the base of the unit. As reported by Smits the measured elevations of the top of the interval varies from 181 to $211 \mathrm{ft}$ above mean sea level and the measured thickness varies between 29 and 86 feet. Thicker parts of the unit are considered to be associated with troughs on the top of the Crouch Branch confining unit.

An important characteristic associated with the Lost Lake aquifer zone is the transition from a confined aquifer near the central source zones to that of an unconfined aquifer towards the south and east. This transition is a result of the decreasing topography and subsequent erosion of the regional Green Clay confining zone. These erosional processes and transition occur outside the extent of the previous A/M Area geologic studies (Aadland et al. 1995) (Smits et al. 1998). In regions where the Green Clay confining zone is absent the Lost Lake aquifer zone represents the water table aquifer and interacts directly with other components of the hydrologic cycle. These interactions include receiving direct recharge from precipitation, exchanges with root zones, and groundwater discharges to regional surface streams. In gaining streams that are typical of the 
coastal plain geology, groundwater is transferred to surface streams water through the hyporheic zone. This zone is considered to comprise the stream bed and banks. The size and geometry of the hyporheic zone surrounding streams vary greatly in time and space. Because of mixing between groundwater and surface water in this zone, the chemical and biological character of the hyporheic zone may differ significantly from the adjacent surface water and groundwater.(Winter et al. 1998) In the current investigation the interactions with regional surface streams is of significant importance. In those regions where the Green Clay confining zone has been eroded by surface streams, these streams will control the discharge of groundwater and may serve as significant receptors of contaminated groundwater from upgradient sources.

Southeast of A/M Area near the intersection of Tims Branch and SRS Road 2 the elevation of the surface tributary Tims Branch decreases below 200 feet mean sea level. This elevation is considered to correspond with contact between the Lost Lake aquifer zone and Green Clay confining unit. Areas where the Green Clay confining zone have been eroded are where the dissolved contaminant plume is most likely to outcrop to a surface receptor. As the surface topography continues to decease along the stream, groundwater and surface water interactions between the Lost Lake aquifer zone and the surface tributary will control the migration of dissolved contaminants from upgradient sources. This region is considered to be the location where the contaminated groundwater present in A/M Area will first discharge to Tims Branch and serves to define the study area for the current characterization activities.

The extent of the study area is presented in Figure 1. This area extends along Tims Branch from SRS Road 2 to SRS Road C. Significant features presented in this figure include the recirculation wells associated with Southern Sector remediation, the conceptual extension of the trichloroethylene plume based on previous seepline characterization activities (Jerome et al. 1999), and the decrease of topography within the stream valley. Within the study area the elevation of the stream decreases by more than 50 feet and has a length of approximately 2.34 miles. Groundwater and contaminant characterization along this region will be of long-term importance to the overall corrective action program in the A/M Area. This long-term importance is a result of the extended travel time associated with transport of contaminants from the ongoing, active remediation systems to the stream receptor.

\section{Contaminant Migration in the Southern Sector}

The portion of the dissolved plume expected to outcrop along Tims Branch is associated with the plume present in the Southern Sector of the A/M Area. This plume is primarily the result of southward migration of dissolved solvent via advective transport from the M-Area Settling Basin and the A-014 Outfall source zones. DNAPL has been detected in the saturated zone above the Green Clay near the M-Area Settling Basin (Looney et al. 1992) with the extent of DNAPL in A/M Area considered to be quite extensive (Jackson et al. 1996). Characterization activities evaluating where aggressive DNAPL remediation technologies could be deployed in the source zone revealed that the highest contaminant levels are observed in relatively thin layers less than 1 foot thick (Jerome et al. 1998). Recent characterization activities associated with the A-014 Outfall have identified DNAPL in the shallow portions of the vadose zone near the headwaters of this historical surface receptor (Jackson et al. 1999). Due to the local groundwater flow patterns, DNAPL present in these areas will serve as a long-term source for dissolved contamination in the southern portions of the Lost Lake aquifer zone. 
Initial remediation programs within the Southern Sector proposed the application of conventional pump and treat technologies at recovery well RWM-16 (Looney and Phifer 1994). This strategy was postponed and a series of airlift recirculation wells were proposed (Jackson and Looney 1996) and subsequently installed to address groundwater remediation in the Southern Sector (White 1999). Simple mass balance calculations, supported by detailed transport simulations, were performed to estimate the cleanup timing and efficiency of the recirculation wells (Aleman and Hamm 1999). These investigations indicated that under nominal operating conditions a significant overlap exists between two adjacent recirculation wells. This overlap creates an increase in the recycling of treated groundwater over that of an individual recirculation well. This increase should have a significant effect on the magnitude and temporal extent of concentrations near the outcrop region.

Recent interest has arisen in using the existing RWM-16 well as the basis of a pump \& treat system using an irrigation based treatment mechanism. The influence of RWM-16 in providing plume containment and control within the Southern Sector has been previously examined using zone of capture analysis techniques (Jackson and Aleman 1995). This analysis indicated that RWM-16 provided capture of only a portion of the groundwater plume as this plume was understood at the time of analysis. Subsequent characterization in the Southern Sector indicates a much larger plume The analysis by Jackson and Aleman revealed that in order to accomplish complete plume control and capture within the Southern Sector additional wells and extraction volume would be required. The analysis could not fully assess the vertical component regarding plume containment and control due to the limited vertical refinement of the Lost Lake aquifer zone.

As presented in previous investigations (Jackson and Looney 1996) the distribution of the dissolved TCE plume within the Southern Sector is influenced by several parameters that result in the distinct vertical stratification of the contaminant plume when examined in cross section. As the plume continues to migrate towards the stream receptor, additional infiltration from above causes the gradual downward migration of the vertically stratified plume. For gaining streams associated with coastal plain deposits, even those that are partially penetrating, the stream serves as the ultimate discharge point for the contaminated groundwater.(Winter et al. 1998) In the vicinity of the stream locally strong vertical gradients exist that result in the upward migration towards the receptor. Understanding of local interactions between groundwater and surface water receptors is of significant importance in the evaluation and characterization of plume outcrops.

In February 1999, a small-scale characterization effort was performed to support future remediation decisions for the Southern Sector of A/M Area and to evaluate regions of potential plume outcrop (Jerome et al. 1999). This study concentrated on groundwater adjacent to the seepline at Tims Branch above and below Steed Pond. The dam associated with Steed Pond has been breached and the pond no longer exists. Due to the site topography and hydrogeology, samples collected north of Steed Pond in this study were associated with discharges from the MArea aquifer zone; while those locations south of Steed Pond provided samples representative of discharges from the Lost Lake aquifer zone. Results from this study indicated that the leading edge of the A/M Area plume in the Lost Lake aquifer zone might be approaching the seepline at Tims Branch below Steed Pond, south of Road 2. Neither trichloroethylene nor tetrachloroethylene were detected in the samples targeting the seepline of the M-Area aquifer zone. 


\section{Groundwater and Surface Water Interactions along Tims Branch}

Tims Branch receives groundwater and surface water from the study area and discharges these waters to Upper Three Runs Creek. This large creek is located at the extreme southern end of the study area and eventually drains most of the A/M Area. Historically A/M process facilities discharged a variety of waste streams that drained into Tims Branch through numerous surface outfalls located upstream of the study area. Historical operations associated with one of these outfalls released an estimated 5 million gallons of water per week (Jackson et al. 1996). Current operational discharges are regulated under a NPDES permit and include the effluent from the extensive pump \& treat systems in the Central and Northern sectors. Since Tims Branch serves as a receptor for potentially contaminated groundwater from the Southern Sector of A/M Area, the component of groundwater that is discharged to the stream from the aquifer is of particular importance. This component of the total stream flow is referred to as the baseflow component.

Historically the United States Geological Survey has provided stream monitoring in the form of gage stations at the intersection of Tims Branch and Road 2 (Station 02197306) and at Tims Branch near Road C, prior to discharge into Upper Three Runs Creek. Historical stream flow measurements in the form of daily average values for the station at Road 2 were available from the USGS for the period between October 1, 1993 through September 30, 1996. Similar records for the station at Road C were available for the periods between March 20, 1974 through September 30,1982 and between February 01, 1984 through September 30, 1996. Stream flow hydrographs for these stations for the period between October 1, 1993 through September 30, 1996 are presented in Figure 2 The USGS no longer maintains the stations along Tims Branch and these stations were removed from the monitoring program in 1996 (Cooney 2000). As indicated in subsequent discussions future collection of stream gage data will be critical in evaluating the long-term performance of remediation activities that are associated with the seepline.

The stream flow hydrographs presented in Figure 2 indicate the total flow in the stream and provide little direct information as to the origin of the water. Traditional hydrologic theories associate a stream flow hydrograph into baseflow and surface-runoff components (Freeze and Cherry 1979; Fetter 1994). The baseflow component is traditionally associated with groundwater discharge and the surface-runoff component with precipitation that enters the stream as overland runoff. Detailed hydrograph analysis is a useful and powerful technique applied in a variety of water-resource investigations. Separation of stream flow hydrographs into base-flow and surface-runoff components is used to estimate the groundwater contribution to the total stream flow.

The USGS has developed a computer program, HYSEP, to systematically perform hydrograph separation. HYSEP (Sloto and Crouse 1996) performs hydrograph separation, estimating the groundwater, or baseflow, component of stream flow. The program provides an automated and consistent method for estimating baseflow. Any of the three hydrograph-separation techniques of Pettyjohn and Henning (1979) can be used. These techniques include the fixed interval, the sliding interval, or local minimum methods. Daily mean stream discharge is used as input to the program in either an American Standard Code for Information Interchange (ASCII) or binary format. Output from the program includes tables, graphs, and data files.

HYSEP was used to analyze the stream flow hydrograph data for the period between October 1993 through October 1996 that is presented in Figure 2. These two stations are located on the upstream and downstream end of the study area and allow for an estimation of the magnitude of 
base-flow in the study area. The results of this analysis are presented in Figure 3 Monthly summary and seasonal distribution tables for the presenting streamflow, baseflow, and runoff summaries for the period between October 1993 through October 1996 are included in the Appendix. These results indicate that the average base-flow in Tims Branch at the intersection of SRS Road 2 is 2.35 cubic feet per second and 5.51 cubic feet per second at the intersection of SRS Road C. Initial approximations split this flux equally between both sides of the stream. These results indicate that there is an increase of 3.16 cubic feet per second across the extent of the study area. This increase is associated with groundwater discharges from the Lost Lake aquifer zone to Tims Branch within the study area. Using a distance of 2.34 miles as the length of stream between these two stations, the rate of increase in groundwater flux per length of stream can approximated.

The value of baseflow as estimated in this investigation was based on data for the period October 1, 1993 through September 30, 1996. Since the end of this period several alterations and modifications have occurred relating to the permitted discharges upstream of the study area that would have impacted the total flow in Tims Branch. In addition numerous events have occurred that may have potential impact on the flows that are associated with the ongoing groundwater remediation activities in A/M Area. Specific examples include the increase in groundwater pumping and subsequent discharge associated with the A2 pump \& treat system in the Northern Sector and the additional extraction wells associated with the Metallurgical Laboratory facility in the Central portion of A/M Area.

As indicated by results of the characterization activities subsequently presented, future collection of stream gage data along Tims Branch will be critical in evaluating groundwater discharges within the study area. This data will provide a basis for determining the magnitude of the stream baseflow that can be combined with detailed information on the structure and extent of the contaminant plume to estimate the contaminant flux to the stream. 


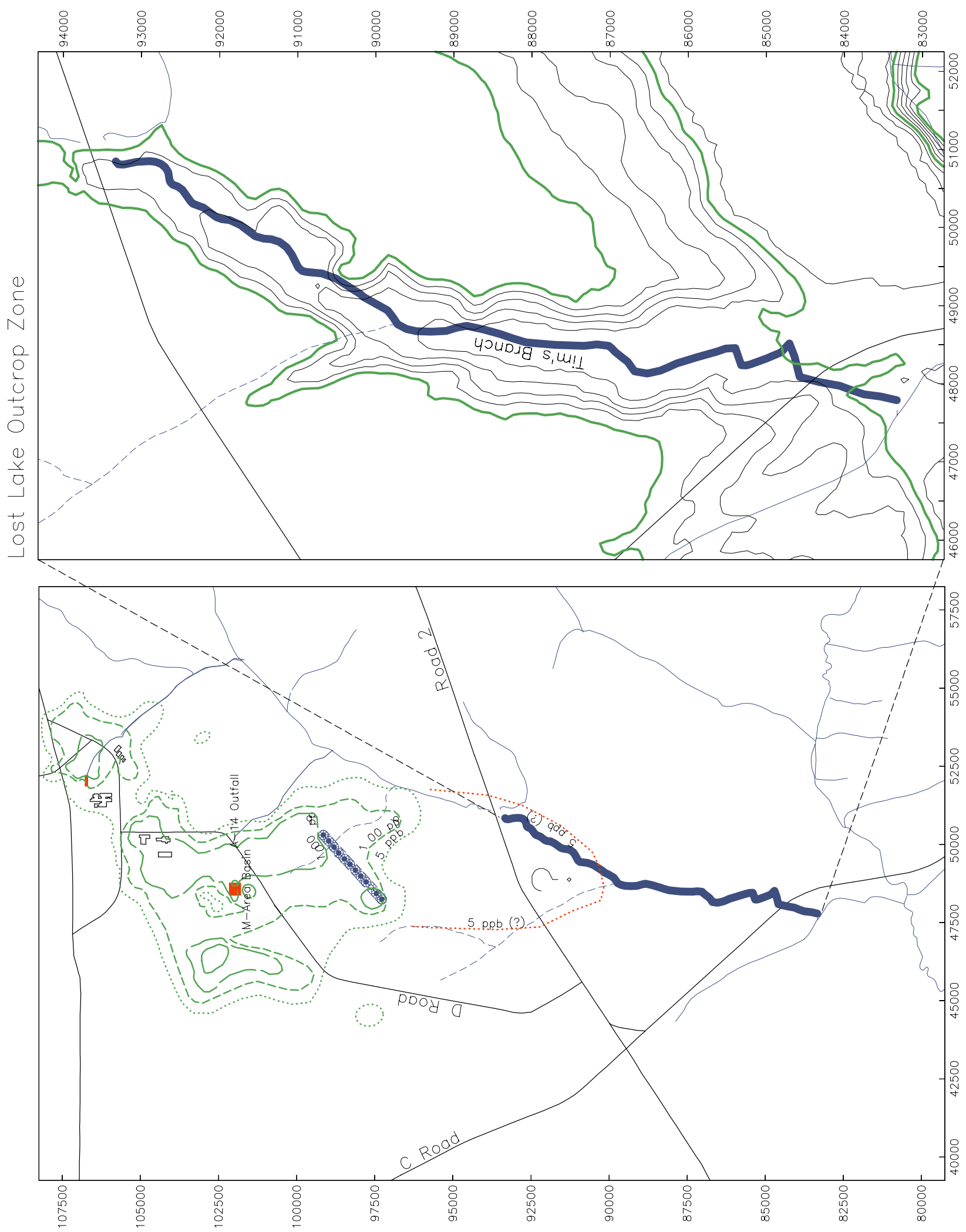

Figure 1: $\quad$ Location of Tims Branch Seepline Study Area Between SRS Road 2 and SRS Road C. 


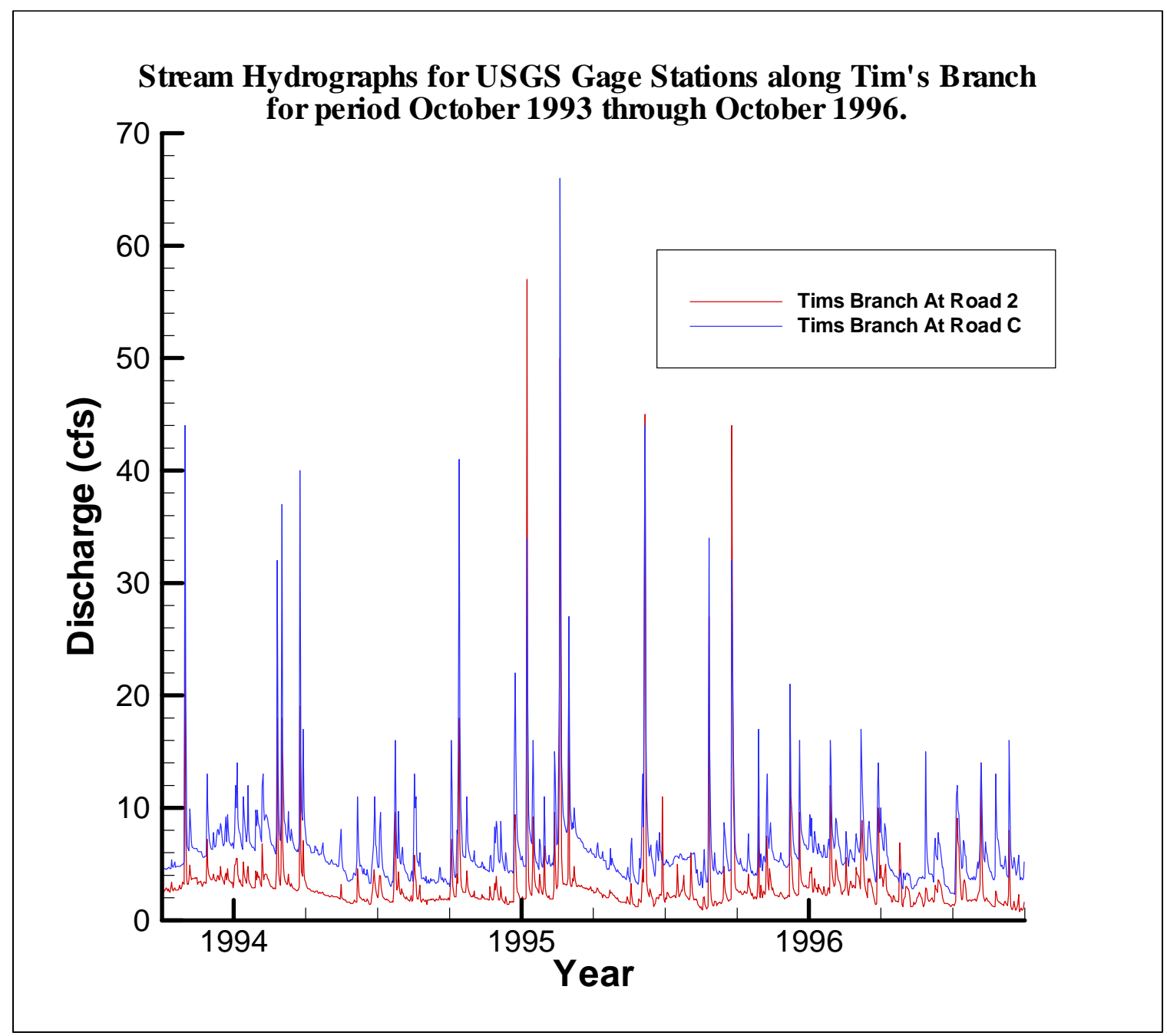

Figure 2: $\quad$ Stream Hydrographs for USGS Gage Stations 02197306 and 02197309 located along Tims Branch at each end of the study area. 
Variation of Surface Runoff and Baseflow for the Period Oct-93 through Oct-96 for Tim's Branch at Road 2 (Station 02197306).

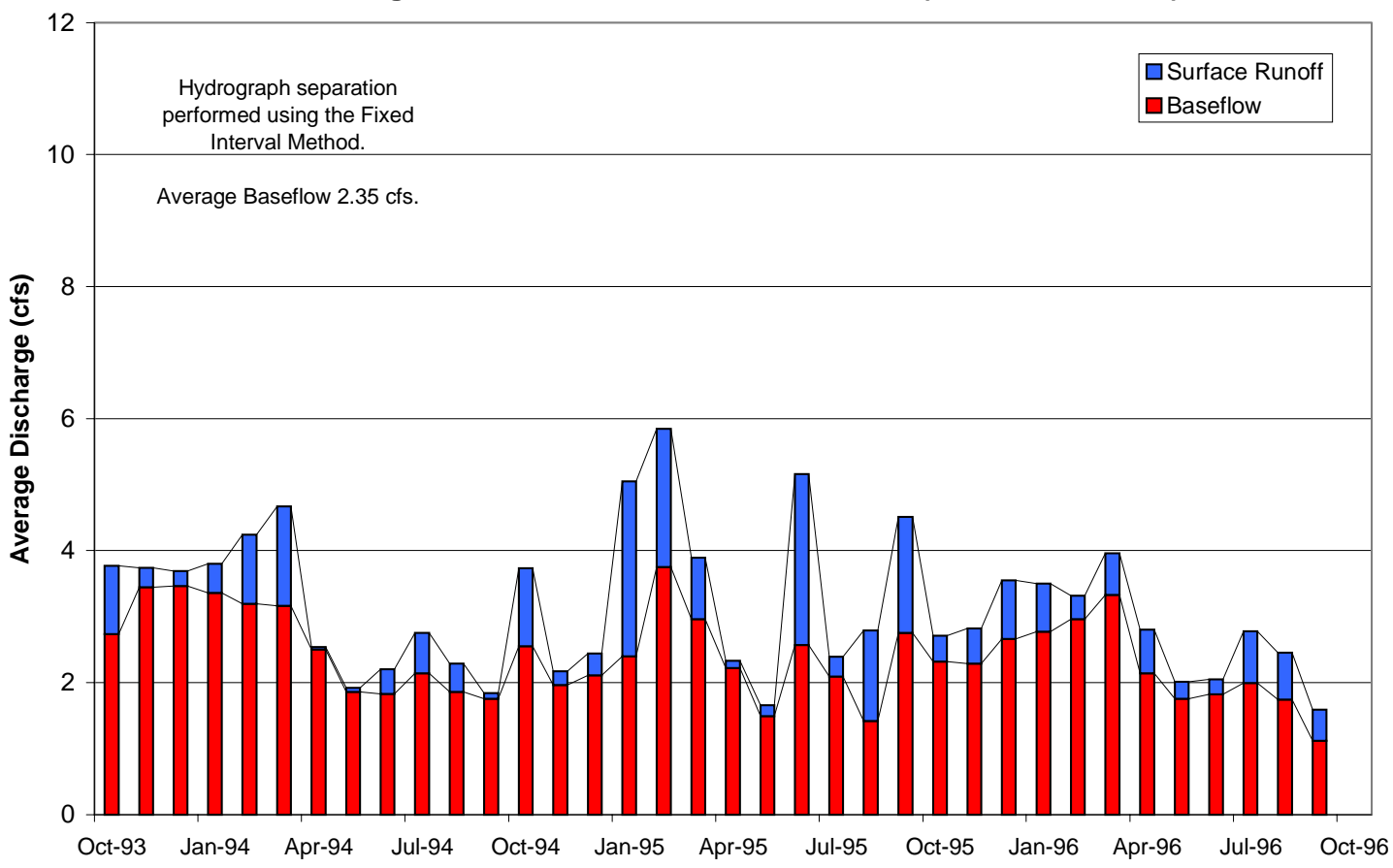

Variation of Surface Runoff and Baseflow for the Period Oct-93 through Oct-96 for Tim's Branch at Road C (Station 02197309).

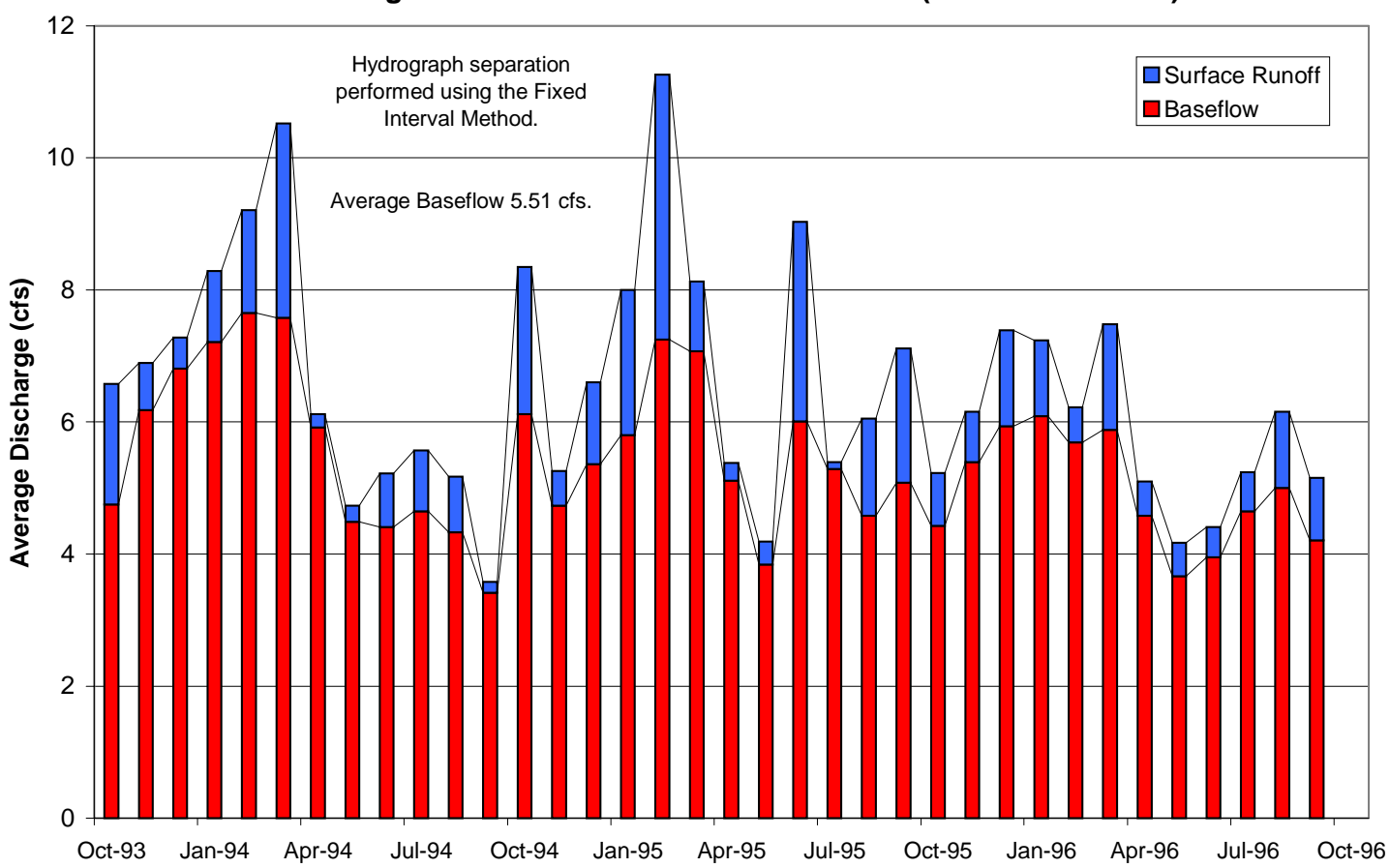

Figure 3: Hydrograph Seperation Results for USGS Stream Gage Stations Along Tims Branch located on each end of the Study Area. 


\section{Approach to Characterization:}

The characterization approach employed in evaluating the lateral extent of volatile organic contaminants outcropping along Tims Branch was dynamic and graded. Initial efforts involved the collection of large quantities of inexpensive data using diffusion based sampling techniques. These results were then used to direct subsequent drilling activities selected to have minimal impact on the surroundings of the seepline. The focus of this activity was on the collection and analysis of depth-discrete sediment samples along the extent of the study area. The drilling activity was followed by the installation of fixed monitoring points along the seepline. These points will provide long-term monitoring to support future remediation activities and to evaluate the potential for phytoremediation or other natural sustainable treatment alternatives.

\section{Stage I: Diffusion Sampling}

Stage I of the characterization activities involved the deployment of passive water-water diffusion samplers along the 12,000 foot segment of Tims Branch. Initial plans were to deploy samplers at approximately 250-foot intervals along the stream. The actual spacing varied based local conditions and access limitations. The samplers were deployed in the stream bank on the northern side of the stream targeting the upgradient flowlines associated with the dissolved contaminant plume in the Southern Sector of A/M area. This activity was designed to aggregately characterize the reach of Tims Branch from Road 2 to Road C using this costeffective sampling technique.

Passive, diffusion based sampling techniques have gained popularity and extensive use by a number of investigators, most notably those associated with the United States Geological Survey(Vroblesky et al. 1996) (Vroblesky and Hyde 1997) (Savoie et al. 1998) (Vroblesky et al. 1999) (Savoie et al. 2000). The concept is based on diffusive transport associated with the concentration gradient between the media under investigation, typically groundwater, and the sampling device. Sampling devices are typically a container containing a sampling matrix that is immersed in the media under investigation. Integral to the sampling device is a diffusive membrane that allows migration of contaminants into the sampling device for later retrieval and analysis. Previous investigations have proposed this sampling approach as a replacement for traditional well sampling techniques (Vroblesky and Hyde 1997) and both as a quantitative tool (e.g. (Savoie et al. 1998)) or as a reconnaissance technique for evaluating the interactions between contaminated groundwater and surface waters tool (Vroblesky et al. 1996). Within the current study area diffusion based sampling techniques were used as reconnaissance tool to identify the potential extent of the outcrop of contamination associated with the Southern Sector.

The diffusion samplers deployed in this investigation consisted of two (2) inexpensive plastic sampling bags each containing approximately $80 \mathrm{ml}$ of de-ionized water housed in a durable plastic flow through container (Challenger 9-inch Tube Cricket Cages, Bass Pro Shops Item\# 38462-985-00). The container was selected for ease of handling, retrieval, and was available at minimal cost. Sampling bags were constructed using commercially available 2 -inch polyethylene natural lay flat tubing that is used in a variety of commercial packing and shipping applications. The polyethylene stock material served as diffusive membrane separating the sampling media from the sampling matrix. The thickness of the polyethylene used was 0.004 -inches and the material is readily available in 1500 -foot rolls. Samplers were deployed approximately 18 to $24-$ inches into the stream bank and allowed to equilibrate with surrounding groundwater. The region 
sampled using the diffusion samplers is considered to be the hyporheic zone (Winter et al. 1998). Initially samplers were deployed at uniform intervals using a fixed length of rope to determine the sample spacing along Tims Branch beginning at Road 2. The actual spacing varied due to local conditions and access limitations to some portions of the stream. As a result relative positions from previous sampling stations were determined using a handheld Global Positioning System (GPS) receiver, model Garmin III Plus. Relative coordinate positions were collected using internal averaging prior to the removal of Selective Availability (SA-ON) for a minimum of 15 minutes.

With the exception of three of the samplers, each sampler was retrieved two weeks following the initial deployment. Upon retrieval of the sampler, $7.5 \mathrm{ml}$ of water was collected in a glass vial and sealed with a Teflon-lined septum top. The assumption is that during the deployment period, the water in the sample bag has reached chemical equilibrium with the water in the hyporheic zone. The sample was then transported to the laboratory and analyzed using a modified headspace analysis technique based on EPA Method 5021. Sample analysis was performed at SRTC laboratories using a Hewlett Packard 5890 Series II gas chromatograph with electron capture (ECD) and flame ionization detectors (FID) in parallel with an automated head space sampler at $70^{\circ} \mathrm{C}$ to determine equivalent water concentrations. The gas chromatograph was calibrated using either stock methanol solutions made with neat (pure) solvents or purchased certified mixtures in methanol that were diluted in de-ionized water to the specific concentrations. The standard concentrations used for the headspace calibration were $3 \mu \mathrm{g} / \mathrm{l}, 5$ $\mu \mathrm{g} / \mathrm{l}, 10 \mu \mathrm{g} / \mathrm{l}, 50 \mu \mathrm{g} / \mathrm{l}, 100 \mu \mathrm{g} / \mathrm{l}, 1 \mathrm{mg} / \mathrm{l}$, and $10 \mathrm{mg} / \mathrm{l}$. The samples were analyzed for Freon-11, Freon-113, 1,1-dichloroethylene, trans-dichloroethylene, cis-dichloroethylene, trichloromethane, 1,1,1-trichloroethane, tetrachloromethane, trichloroethylene and tetrachloroethylene.

In the interpretation of the analytical results, samples with concentrations above the minimum standard used, typically $3 \mu \mathrm{g} / \mathrm{l}$, are reported as measured when responses from the gas chromatograph detectors are observed at the appropriate retention time. In samples where a response is observed in the detector output at the appropriate retention time, yet the response is below that of the minimum standard, the sample is considered to contain trace amounts of the specific compound associated with the observed retention time. These samples are interpreted as containing low-levels of the compound, below $3 \mu \mathrm{g} / \mathrm{l}$, and are reported in the tables as "Trace" and referred to in the text as indicated. Samples where no response was observed from the analytical instruments are reported as zero and denoted by a dashed line in the accompanying tables.

A total of 53 diffusion samplers were deployed in 34 locations along the extent of the study area. The analytical results obtained from the water-water diffusion samplers deployed in the stream bank are presented in Table 1 and the corresponding location of each of the sampling stations is presented in Figure 4. All of the diffusion samplers were deployed on the western side of Tims Branch to intercept groundwater associated with the Southern Sector of A/M Area. As presented in Figure 4, those stations where the volatile organic compounds trichloroethylene and tetrachloroethylene were indicated or measured are presented with filled symbols. As presented in Table 1, measurable quantities were observed at the upper end of the study area near SRS Road 2. This is based on reported values associated with samples TBD-035, TBD-037, and TBD-007, and TBD-063 deployed at Stations 1, 4, and 02A. Moving downstream the concentrations decrease below the minimum standard level and numerous, duplicate samples indicated the presence of trichloroethylene and tetrachloroethylene below $3 \mu \mathrm{g} / \mathrm{l}$. The multiple 
sample results reported at the various stations presented in Table 1 are associated with multiple sampling events at each station. The variability in the presented sample results is considered to be associated with storm events that have a significant effect on the flow in the hyporheic zone. Considering this variability and uncertainty the plume from the Southern Sector is considered to occur over a distance of approximately 2200 feet south of Road 2.

As indicated in Figure 4 a large section of Tims Branch between Stations 14A and 12 was not investigated using diffusion based characterization techniques. This area was not sampled due to elevated surface water levels associated with beaver habitat. Within this portion of the study area the stream depth was observed to begin increasing near Station 9 and continually increased until conditions prevented further access near Station 14A. In this vicinity standing water was observed approaching depths of 1 meter or more with the width of the stream increasing significantly. Indications of additional beaver habitat were observed in the southern portion of the study area near Station 20A. It is uncertain how the impoundment of water at the surface will effect the discharge and geometry of a contaminant plume. Aspects and uncertainties of these interactions are presented in the Interpretation and Discussion section beginning on page 45

As indicated by the results presented in Table 1, no significant levels of anaerobic degradation products were observed with the diffusion samplers. The results of this investigation were subsequently used to identify those regions where the VOC plume has outcropped into Tims Branch. 
Table 1: $\quad$ Results from Diffusion Samplers Deployed along Seepline Between SRS Road 2 and SRS Road C.

\begin{tabular}{|c|c|c|c|c|c|c|c|c|c|}
\hline \multicolumn{2}{|c|}{ Sum of Conc. (ug/L) } & \multirow{2}{*}{\begin{tabular}{|r|} 
Analyte \\
PCE
\end{tabular}} & \multirow[b]{2}{*}{ TCE } & \multirow[b]{2}{*}{ C-DCE } & \multirow[b]{2}{*}{ T-DCE } & \multirow[b]{2}{*}{ 11DCE } & \multirow[b]{2}{*}{ CHCL3 } & \multirow[b]{2}{*}{ CCL4 } & \multirow[b]{2}{*}{ TCA } \\
\hline Station & Sample ID & & & & & & & & \\
\hline \multirow[t]{6}{*}{1} & TBD-001 & - & - & - & - & - & - & - & - \\
\hline & TBD-035 & 3.64 & 10.25 & - & - & - & - & - & - \\
\hline & TBD-037 & Trace & 7.31 & - & - & - & - & - & - \\
\hline & TBD-039 & Trace & Trace & - & - & - & - & - & - \\
\hline & TBD-067 & Trace & 3.00 & - & - & - & - & - & - \\
\hline & TBD-069 & Trace & Trace & - & - & - & - & - & - \\
\hline 2 & TBD-003 & Trace & Trace & - & - & - & - & - & - \\
\hline 3 & TBD-005 & Trace & 3.58 & - & - & - & - & - & - \\
\hline 4 & TBD-007 & 3.23 & 8.68 & - & - & - & - & - & - \\
\hline 5 & TBD-009 & Trace & - & - & - & - & - & - & - \\
\hline 6 & TBD-011 & Trace & - & - & - & - & - & - & - \\
\hline 7 & TBD-013 & Trace & - & - & - & - & - & - & - \\
\hline 8 & TBD-015 & Trace & - & - & - & - & - & - & - \\
\hline 9 & TBD-017 & Trace & - & - & - & - & - & - & - \\
\hline 10 & TBD-019 & - & - & - & - & - & - & - & - \\
\hline 11 & TBD-021 & - & - & - & - & - & - & - & - \\
\hline 12 & TBD-022 & - & - & - & - & - & - & - & - \\
\hline 13 & TBD-023 & - & - & - & - & - & - & - & - \\
\hline 14 & TBD-024 & - & - & - & - & - & - & - & - \\
\hline \multirow[t]{2}{*}{15} & TBD-025 & - & - & - & - & - & - & - & - \\
\hline & TBD-026 & - & - & - & - & - & - & - & - \\
\hline \multirow[t]{2}{*}{$02 \mathrm{~A}$} & TBD-063 & 3.72 & 10.15 & - & - & - & - & - & - \\
\hline & TBD-065 & Trace & Trace & - & - & - & - & - & - \\
\hline \multirow[t]{2}{*}{ 03A } & TBD-060 & Trace & Trace & - & - & - & - & - & - \\
\hline & TBD-062 & Trace & Trace & - & - & - & - & - & - \\
\hline \multirow[t]{2}{*}{$05 A$} & TBD-054 & Trace & Trace & - & - & - & - & - & - \\
\hline & TBD-056 & Trace & Trace & - & - & - & - & - & - \\
\hline 06A & TBD-051 & - & - & - & - & - & - & - & - \\
\hline \multirow[t]{2}{*}{ 07A } & TBD-048 & Trace & Trace & - & - & - & - & - & - \\
\hline & TBD-050 & Trace & Trace & - & - & - & - & - & - \\
\hline 08A & TBD-045 & Trace & - & - & - & - & - & - & - \\
\hline 09A & TBD-043 & Trace & - & - & - & - & - & - & - \\
\hline $10 A$ & TBD-040 & - & - & - & - & - & - & - & - \\
\hline \multirow[t]{2}{*}{$11 \mathrm{~A}$} & TBD-027 & Trace & 5.60 & - & - & - & - & - & - \\
\hline & TBD-032 & Trace & - & - & - & - & - & - & - \\
\hline \multirow[t]{2}{*}{ 12A } & TBD-083 & - & - & - & - & - & - & - & - \\
\hline & TBD-085 & - & - & - & - & - & - & - & - \\
\hline 13A & TBD-087 & - & - & - & - & - & - & - & - \\
\hline $14 \mathrm{~A}$ & TBD-089 & - & - & - & - & - & - & - & - \\
\hline & TBD-091 & - & - & - & - & - & - & - & - \\
\hline $15 \mathrm{~A}$ & TBD-093 & - & - & - & - & - & - & - & - \\
\hline $16 \mathrm{~A}$ & TBD-095 & - & - & - & - & - & - & - & - \\
\hline 17A & TBD-071 & - & - & - & - & - & - & - & - \\
\hline $18 \mathrm{~A}$ & TBD-074 & - & - & - & - & - & - & - & - \\
\hline 19A & TBD-077 & - & - & - & - & - & - & - & - \\
\hline $20 A$ & TBD-080 & - & - & - & - & - & - & - & - \\
\hline & TBD-082 & - & - & - & - & - & - & - & - \\
\hline $21 \mathrm{~A}$ & TBD-40-W & - & - & - & - & - & - & - & - \\
\hline $22 A$ & TBD-41-W & - & - & - & - & - & - & - & - \\
\hline $23 A$ & TBD-42-W & - & - & - & - & - & - & - & - \\
\hline $24 A$ & TBD-43-W & - & - & - & - & - & - & - & - \\
\hline $25 A$ & TBD-44-W & - & - & - & - & - & - & - & - \\
\hline $26 A$ & TBD-45-W & - & - & - & - & - & - & - & - \\
\hline
\end{tabular}


Lost Lake Outcrop Zone

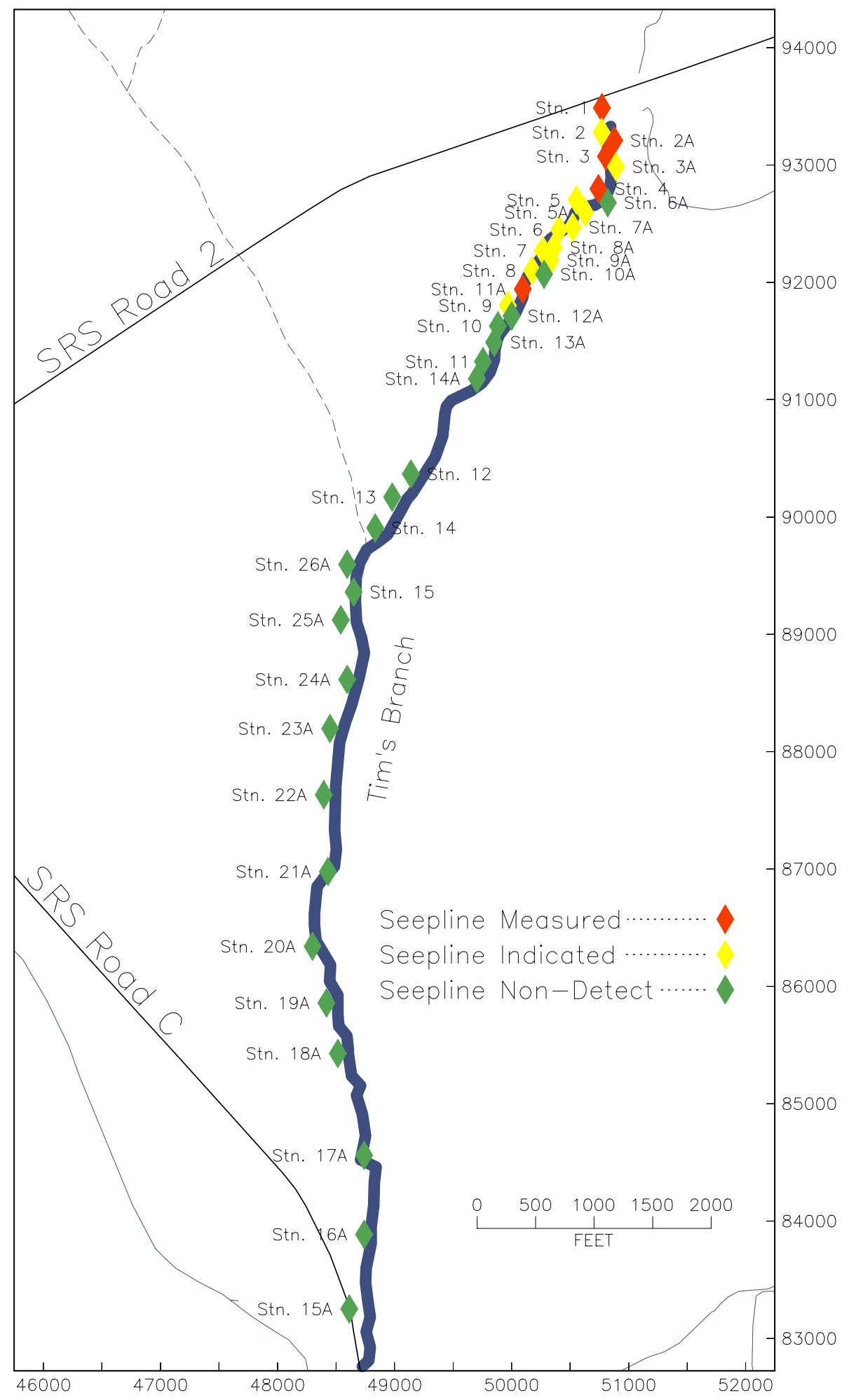

Figure 4: $\quad$ Location of Diffusion Samplers Deployed along Seepline Between SRS Road 2 and SRS Road C. 


\section{Stage II: Sediment Coring}

Stage II characterization activities involved the collection and analysis of sediment samples from specific regions of the seepline that were identified in the FY99 characterization activities (Jerome et al. 1999) and from the results of the Stage I Diffusion Sampling associated with this investigation. Those areas targeted were the regions of the seepline where the dissolved volatile organic plume was considered to be outcropping along Tims Branch. In this portion of the investigation a vibracoring (Smith 1984; Smith 1987; Thompson et al. 1991) coupled with the collection of depth-discrete sediment samples was selected as the primary characterization technique.

Vibracoring works on the principle of liquefaction or fluidization of fine-grained sediments, and the displacement of these sediments to allow the passage of a core barrel. The technique is most effective in saturated and soft materials (Smith 1987). The equipment associated with the technique is lightweight and portable, allowing collection of sediments in remote areas. Most fine-grained saturated fluvial and deltaic deposits are reported to be relatively easy to core with depths of penetration on the order of 18 to 20 feet obtainable (Smith 1984). For characterizing the remote portions of the Tims Branch seepline, vibracoring techniques were selected due to the minimal damage to the environment when compared to traditional drilling technologies as the equipment and materials are relatively portable. In addition the reported penetration depths make the approach ideal for characterization associated with groundwater outcrop regions near streams.

In this portion of the investigation a total of twenty-one (21) 2-inch sediment cores were collected using vibracoring equipment. Following collection, the core was split in the field and depth-discrete sediment samples were collected and analyzed for either volatile organic compounds or for microbiological activity. This involved the collection of sediment samples at 1 -foot intervals for analysis. This vertical sampling distance included the compaction effects associated with vibracoring and was accounted for in the data analysis and interpretation. In this interpretation each sediment sample represented a foot sample of compressed core. This length was scaled in the interpretation based on the ratio of the total core penetration and recovery length.

\section{VOC Analysis}

The technique used for volatile analysis was a modified version of EPA Method 5021 and has been used in environmental characterization by SRS since 1991. In this technique an approximate 2 cubic centimeter plug sample of the sediment was collected from the core using a modified plastic syringe. The plug was then transferred to a 22 -ml headspace vial and $5 \mathrm{ml}$ of deionized pure water was added. The glass vial was then sealed with a crimped Teflon-lined septum top for headspace analysis. Duplicate samples were collected at each depth and all samples were transported to laboratory facilities for analysis.

Volatile analysis of sediment samples was performed at SRTC laboratories using a Hewlett Packard 5890 Series II gas chromatograph with electron capture (ECD) and flame ionization detectors (FID) in parallel with an automated head space sampler at $70^{\circ} \mathrm{C}$ to obtain equivalent water concentrations. Mass soil concentrations were calculated based on a corrected head space volume from the $7.5 \mathrm{ml}$ of water standards to the mass estimated volume of water/soil matrix. 
These values were then corrected for the mass difference between the soil and water. The gas chromatograph was calibrated using either stock methanol solutions made with neat (pure) solvents or purchased certified mixtures in methanol that were diluted in de-ionized water to specific concentrations. Due to the extremely low concentration levels associated with these samples reagent blanks of pure de-ionized water were included between individual coring sets to ensure that the transfer lines and column were adequately flushed of residual solvents. The standard concentrations used for the headspace calibration were $3 \mu \mathrm{g} / 1,5 \mu \mathrm{g} / 1,10 \mu \mathrm{g} / 1,50 \mu \mathrm{g} / \mathrm{l}$, $100 \mu \mathrm{g} / \mathrm{l}, 1 \mathrm{mg} / \mathrm{l}$, and $10 \mathrm{mg} / \mathrm{l}$. The samples were analyzed for Freon-11, Freon-113, 1,1dichloroethylene, trans-dichloroethylene, cis-dichloroethylene, trichloromethane, 1,1,1trichloroethane, tetrachloromethane, trichloroethylene and tetrachloroethylene.

Interpretation of the analytical results in this portion of the investigation is consistent with the terminology established with the results from the Diffusion Sampling. Analytical results considered to have equivalent water concentrations greater the minimum standard used are reported as measured. Results having a response at the appropriate retention time, yet below the minimum are considered to contain trace amounts of the specific compound and are interpreted as containing low-levels of the compound. These are reported in the tables as "Trace" and referred to in the text as indicated. Samples where no response was observed from the analytical instruments are interpreted as Non-Detects and reported as "ND" in the accompanying tables.

A total of twenty-one (21) 2-inch sediment cores were collected along Tims Branch between Road 2 and Road C. As presented in previous discussions this is the region of anticipated outcrop of the dissolved plume associated with the Southern Sector of A/M Area. Previous investigations (Jerome et. al., 1999) had identified a potential outcrop region near the power line crossing near SRS Northing 89,900 feet. These locations were identified as SSL-05 and SSL-06 in the previous investigation. Diffusion based sampling activities indicated that trichloroethylene and tetrachloroethylene was present in the hyporheic zone for a distance of approximately 2200 feet south of Road 2. Both of these regions were targeted for additional characterization in this portion of the investigation. In addition, numerous additional cores were collected through out the study area. The majority of the cores were located on the northern or receptor side of the stream. One core location (SSL-18) was taken in the middle of the stream and two additional cores (SSL-19 and SSL-32) were collected on the southern side of the stream. Location SSL-20 of this investigation corresponds with location SSL-6 associated with previous investigation (Jerome et al. 1999).

Table 2 presents a summary of vibracoring performed along Tims Branch to support these characterization activities. A total of 245 feet of core was collected from nineteen (19) different locations, with two (2) cores collected at locations SSL-13/31 and SSL-19/32. Information of significant note in Table 2 includes the "Depth of Penetration", the "In-Situ Compaction", and the "Recovery Length." The targeted depth of each core was anticipated to be 20 feet, this depth was based on ideal conditions and a number of local parameters limited the maximum penetration at several locations. The maximum penetration depth obtained was $17 \mathrm{ft}-6$ in at SSL24 and the minimum penetration depth was $5 \mathrm{ft}-11$ in at SSL-18, and the average depth of penetration was on the order of 12 feet.

Position locations for the sediment borings were determined using a handheld Global Positioning System (GPS) receiver, model Garmin III Plus. Coordinate positions were collected using internal averaging post Selective Availability (SA-OFF) for a minimum of 15 minutes or until the Estimated Accuracy reported by the equipment was below 30 feet. The positions reported 
from this equipment are based on the WGS 84 datum. These values were then converted to the SRP Coordinate system through North American Datum of 1927, the basis of this coordinate system. The location of vibracores that were collected along the seepline between SRS Road 2 and SRS Road C are presented in Figure 5. As indicated previously in Figure 4, a large section of Tims Branch was not sampled due to elevated surface water levels associated with local beaver habitat. This region is located between cores SSL-17 and SSL-23/24. Locations SSL-23 and SSL-24 were located adjacent to a large surface impoundment considered to be associated with the extensive beaver habitat present in the vicinity. Coring SSL-23 was located near the water's edge and SSL-24 was located west near what appeared to be the edge of the stream valley.

A total of 194 sediment samples, including duplicates, were collected in the field for analysis using the gas chromatograph based headspace analysis technique. Table 3 through Table 22 presents a summary of the VOC results from this sampling activity. As presented in this series of tables the concentrations of volatile compounds observed were extremely low and were typically below the minimum standard used for calibration. Although not quantifiable the numerous samples indicated the presence of trichloroethylene and tetrachloroethylene. In the subsequent tables, those samples marked as Invalid were associated with analytical errors, most commonly associated with a leaking sample vial during analysis. This is indicated when the electron capture detector (ECD) fails to observe a substantial air peak. Following the analysis, visual inspection of numerous of the vials considered to have leaked identified the presence of grains of small sand or grit under the septum cap. This was most likely the source of the leaks and reinforces the need for care and rigorous sampling handling techniques during field collection.

A portion of the samples that indicated the presence of trichloroethylene and tetrachloroethylene are considered to have concentrations that are below the actual concentration results due to drainage of groundwater from the core during collection. As identified (Eddy et al. 1991) the headspace method employed often results in volatile organic loss during sampling in sediments of less than $30 \%$ clay. This aspect was observed with samples associated with the Crouch Branch aquifer (Jackson et al. 1997) where it was theorized that these effects would increase with sample depth as a result of drainage from the core during collection. For the vibracoring activities performed in this investigation, the sediment size was observed to generally increase with depth. Generally the sediments associated with the deeper portion of each core were classified as coarse sands with very little fine content. As such they would experience significant drainage during removal. This observation was consistent for all the cores collected and was considered to be associated with the highly fluvial aspect of the depositional environment. In addition to potential VOC loss associated with course grained drainage; additional drainage may have been promoted by the vibrating action integral to the characterization approach.

Due to the low concentrations observed, to effectively interpret the results from the depthdiscrete results, the results from both samples collected at each interval were used to determine the extent of the plume outcrop. In this determination the plume was considered to exist at the location if either one of the primary constituents, trichloroethylene and tetrachloroethylene, was above the minimum standard level used or if both samples that were collected at the interval indicated the presence of the same constituent. Although the logic of the later approach is subjective, the approach provides an indicator as to where the plume may be outcropping. The results of this interpretation for trichloroethylene and tetrachloroethylene are presented in Figure 6 and Figure 7. These generally indicated the presence of of trichloroethylene and tetrachloroethylene at locations SSL-12, SSL-13, SSL-14, SSL-15, SSL-17, SSL-18, SSL-22, 
and SSL-31. With the exception of SSL-18 that was collected in the middle of the stream, the results presented in Figure 6 and Figure 7 consistently suggest that the contamination is present in the deepest portion of the cores. This distribution is consistent with the location of the plume in the lower portion of the Lost Lake aquifer(Jackson and Looney 1996). As indicated in Table 3 through Table 22, anaerobic degradation products were not observed in the depth-discrete core samples. As previously mentioned location SSL-20 of this investigation corresponded with location SSL-6 of previous investigations (Jerome et al. 1999). Sediment results from this location did not indicate the presence of contaminants using the criteria established, however as indicated in Table 10, the presence of trichloroethylene was indicated in one sample each at the two deepest depths. Coring SSL-12, located downstream of SSL-20, and SSL-22, located upstream of SSL-20, indicated the presence of trichloroethylene using the criteria established. The results associated with core location SSL-12 are presented in Table 3 and Figure 6 and the results for SSL-22 are presented in Table 11 and Figure 7

Based on the distribution and location of these results, the projected stream reach for the A/M Area plume outcrop is considered to be in a 1700-foot region between SSL-13 and SSL-17 south of SRS Road 2. In addition, these results also indicate that the plume may also be present between boring SSL-12 and SSL-21. This area is near the southern extent of the increased surface impoundment associated with the extensive beaver habitat previously mentioned. The locations where trichloroethylene and tetrachloroethylene were indicated using the established criteria are presented in Figure 5 with filled symbols.

The regions of potential outcrop identified are consistent with conceptual model for groundwater flow and contaminant outcropping from A/M Area. As with any screening method the headspace data is subjective and was collected to allow investigators to cost effectively understand the dynamics and possible extent of organic contaminants along the outcrop region. In applying this approach the final objective is to use a weight of evidence approach to compare results from numerous characterization activities. This is especially important when examining concentrations on the level of those observed in this and the previous portion of the investigation.

\section{Microbial Analysis}

Comprehensive analysis of specific microbial populations and characterization of the metabolic activity of microbial communities is used to predict the bioremediation potential of a natural system. These analyses can enable monitoring the activity of specific microorganisms in reducing and/or removing harmful groundwater contaminants. For this project five soil samples were collected from each of two (2) sediment cores. The samples were collected from sites SSL31 and SSL-32 along the Tims Branch seepline. The sediment samples from both sites ranged in depth from surface/rhizosphere soils to approximately $12 \mathrm{ft}$ below ground surface (bgs). The sediment samples were transported in sterile polyethylene bags for immediate microbiological processing within two hours of collection.

Total microbial population densities in the sediment samples were determined by the Acridine Orange Direct Count (AODC) Method (Balkwill 1989). The AODC technique enumerates all present bacteria including live, dead, aerobic and anaerobic. The viable microbial population densities of aerobic and facultative heterotrophic bacteria in groundwater and soils were determined using spread plate techniques. Low concentrations (1\%) of Peptone-TrypticaseYeast extract-Glucose (PTYG) media was used (Balkwill 1989). These results are presented as colony forming units (CFU). The microbial communities in four sediment samples, (SSL-31-01 
\& 05, SSL-32-01 \& 05) were further characterized by phospholipid fatty acid content (PLFA Analysis) as described by Tunlid and White (Tunlid and White 1991).

Microbial densities were lowest in sample SSL-32-05 and highest in sample SSL-32-01 (Figure 8 and Figure 9. The microbial densities of the surface/rhizosphere samples, SSL-31-01 and SSL-32-01, were similar to those found in previous soil studies in this seepline area (Brigmon et al. 1998; Brigmon et al. 1999). Similarly, biomass content as determined by PLFA in the soil samples was lowest in sample SSL-32-05 and highest in sample SSL-32-01. The PLFA profiles showed that the samples, with the exception of SSL-32-05, contained relatively diverse microbial communities that are primarily composed of Gram-negative bacteria (indicated by percentage of monoenoic PLFA) indicating bioremediation potential. In particular the ratio of sulfate reducing bacteria (SRB) to total community structure is a good indication of anaerobic dechlorination potential in SSL-31-05. 
(This Page Intentionally Blank) 
Table 2:

Summary of Vibracoring Along Tims Branch in Support of Seepline Characterization Actvities.

\begin{tabular}{|c|c|c|c|c|c|c|c|}
\hline Boring ID & Date & $\begin{array}{l}\begin{array}{l}\text { SRS Coordinates } \\
\text { (See Text) }\end{array} \\
\end{array}$ & Location Description & $\begin{array}{c}\text { Depth of } \\
\text { Penetration }\end{array}$ & $\begin{array}{c}\text { In-Situ } \\
\text { Compaction }\end{array}$ & $\begin{array}{c}\text { Recovery } \\
\text { Length }\end{array}$ & Comments \\
\hline SSL-12 & $7 / 6 / 00$ & $\begin{array}{l}\text { N } 89406 \\
\text { E } 48461\end{array}$ & $\begin{array}{l}\text { South of powerline just inside treeline near the central } \\
\text { portion of the study area. }\end{array}$ & $10 \mathrm{ft}-0$ in & 45 in & $5 \mathrm{ft}-7$ in & $\begin{array}{l}\text { Lost 5-inches of material from base. Required six attempts. Collected } \\
\text { six (6) sediment samples with duplicates for VOC analysis. }\end{array}$ \\
\hline SSL-13 & $7 / 6 / 00$ & $\begin{array}{l}\text { N } 93315 \\
\text { E } 50570\end{array}$ & $\begin{array}{l}\text { South of Road } 2 \text { behind Steed Pond on north side of } \\
\text { stream, near USGS Gage Station } 02197306 .\end{array}$ & $9 \mathrm{ft}-1$ in & 34 in & $6 \mathrm{ft}-2$ in & Collected six (6) sediment samples with duplicates for VOC analysis. \\
\hline SSL-14 & $7 / 6 / 00$ & $\begin{array}{l}\text { N } 92970 \\
\text { E } 50625\end{array}$ & $\begin{array}{l}\text { Downstream of Location SSL-13 } 350 \text { feet, near Stream } \\
\text { Diffusion Station 3A. }\end{array}$ & $10 \mathrm{ft}-6$ in & 37 in & $7 \mathrm{ft}-3$ in & Collected seven (7) sediment samples with duplicates for VOC analysis. \\
\hline SSL-15 & $7 / 6 / 00$ & $\begin{array}{l}\text { N } 92697 \\
\text { E } 50443\end{array}$ & $\begin{array}{l}\text { Downstream of Location SSL-14 } 325 \text { feet, near Stream } \\
\text { Diffusion Station 6A. }\end{array}$ & $11 \mathrm{ft}-2 \mathrm{in}$ & 52 in & $6 \mathrm{ft}-5$ in & $\begin{array}{l}\text { Lost 4-inches from base. Collected six (6) sediment samples with } \\
\text { duplicates for VOC analysis. }\end{array}$ \\
\hline SSL-16 & $7 / 7 / 00$ & $\begin{array}{l}\text { N } 92442 \\
\text { E } 50207\end{array}$ & $\begin{array}{l}\text { Downstream of Location SSL-15 } 350 \text { feet, near Stream } \\
\text { Diffusion Station 8A. }\end{array}$ & $11 \mathrm{ft}-0$ in & 32 in & $8 \mathrm{ft}-4$ in & Collected eight (8) sediment samples with duplicates for VOC analysis. \\
\hline SSL-17 & $7 / 7 / 00$ & $\begin{array}{l}\text { N } 92115 \\
\text { E } 49988\end{array}$ & $\begin{array}{l}\text { Downstream of Location SSL-16 } 400 \text { feet, near Stream } \\
\text { Diffusion Station 11A. }\end{array}$ & $12 \mathrm{ft}-6$ in & 57 in & $7 \mathrm{ft}-9$ in & Collected eight (8) sediment samples with duplicates for VOC analysis. \\
\hline SSL-18 & $7 / 7 / 00$ & $\begin{array}{l}\text { N } 93406 \\
\text { E } 50752\end{array}$ & $\begin{array}{l}\text { In Tims Branch Channel at USGS Gage Station } \\
02197306 .\end{array}$ & $5 \mathrm{ft}-11$ in & 54 in & $3 \mathrm{ft}-4$ in & $\begin{array}{l}\text { Four attempts, difficult coring due to stiff clay. Collected two (2) } \\
\text { sediment samples with duplicates for VOC analysis. }\end{array}$ \\
\hline SSL-19 & $7 / 7 / 00$ & $\begin{array}{l}\text { N } 93461 \\
\text { E } 50916\end{array}$ & $\begin{array}{l}\text { South of Road } 2 \text { behind Steed Pond on south side of } \\
\text { stream, near USGS Gage Station } 02197306 .\end{array}$ & $7 \mathrm{ft}-8$ in & 37 in & $4 \mathrm{ft}-9$ in & $\begin{array}{l}\text { Core collected for geologic information on stream valley. No samples } \\
\text { collected for VOC analysis. }\end{array}$ \\
\hline SSL-20 & $7 / 10 / 00$ & $\begin{array}{l}\text { N } 89898 \\
\text { E } 48628\end{array}$ & $\begin{array}{l}\text { North of power line cut near GeoProbe location SSL-6 } \\
\text { from Jerome, } 1999 \text { study. }\end{array}$ & $14 \mathrm{ft}-5 \mathrm{in}$ & 63 in & $9 \mathrm{ft}-2$ in & Collected nine (9) sediment samples with duplicates for VOC analysis. \\
\hline SSL-21 & $7 / 10 / 00$ & $\begin{array}{l}\text { N } 90260 \\
\text { E } 48952\end{array}$ & $\begin{array}{l}\text { Approximately } 450 \text { feet north of Location SSL-21 } \\
\text { positioned on the toe of the slope and wetland. }\end{array}$ & $15 \mathrm{ft}-0$ in & 54 in & $9 \mathrm{ft}-3$ in & $\begin{array}{l}\text { Collected eight (8) sediment samples with duplicates for VOC analysis. } \\
\text { No sample from "6-Foot" interval due to wood fragments. }\end{array}$ \\
\hline SSL-23 & $7 / 10 / 00$ & $\begin{array}{l}\text { N } 91260 \\
\text { E } 49434\end{array}$ & $\begin{array}{l}\text { Near water edge in central portion of the extensive } \\
\text { beaver habitat. }\end{array}$ & $11 \mathrm{ft}-7$ in & 59 in & $6 \mathrm{ft}-7 \mathrm{in}$ & Collected seven (7) sediment samples with duplicates for VOC analysis. \\
\hline SSL-24 & $7 / 10 / 00$ & $\begin{array}{l}\text { N } 91260 \\
\text { E } 49634\end{array}$ & $\begin{array}{l}\text { East of location SSL-23 near break in topography } \\
\text { considered to be associated with ancient fluvial channel }\end{array}$ & $17 \mathrm{ft}-6$ in & 83 in & $10 \mathrm{ft}-7 \mathrm{in}$ & $\begin{array}{l}\text { Collected eleven (11) sediment samples with duplicates for VOC } \\
\text { analysis. }\end{array}$ \\
\hline SSL-25 & $7 / 11 / 00$ & $\begin{array}{l}\text { N } 84405 \\
\text { E } 48643\end{array}$ & $\begin{array}{l}\text { Upstream of railroad track and Tims Branch near } \\
\text { Diffusion Station 17A. }\end{array}$ & $14 \mathrm{ft}-9$ in & 89 in & $7 \mathrm{ft}-4$ in & Collected seven (7) sediment samples with duplicates for VOC analysis. \\
\hline SSL-26 & $7 / 11 / 00$ & $\begin{array}{l}\text { N } 85696 \\
\text { E } 48279\end{array}$ & $\begin{array}{l}\text { Approximately } 1350 \text { feet north of location SSL-25 near } \\
\text { Diffusion Station 18A. }\end{array}$ & $8 \mathrm{ft}-10 \mathrm{in}$ & 43 in & $5 \mathrm{ft}-3$ in & $\begin{array}{l}\text { Hard coring, two attempts. Collected six (6) sediment samples with } \\
\text { duplicates for VOC analysis. }\end{array}$ \\
\hline SSL-27 & $7 / 11 / 00$ & $\begin{array}{l}\text { N } 86951 \\
\text { E } 48134\end{array}$ & $\begin{array}{l}\text { North of location SSL-26 } 1250 \text { feet. Evidence of stream } \\
\text { braiding. }\end{array}$ & $13 \mathrm{ft}-2$ in & 86 in & $6 \mathrm{ft}-0$ in & Collected six (6) sediment samples with duplicates for VOC analysis. \\
\hline SSL-28 & $7 / 11 / 00$ & $\begin{array}{l}\text { N } 83459 \\
\text { E } 48588\end{array}$ & Southern most boring 950 feet south of location SSL-25. & $12 \mathrm{ft}-9$ in & 65 in & $6 \mathrm{ft}-7$ in & $\begin{array}{l}\text { Lost 7-inches from base. Collected seven (7) sediment samples with } \\
\text { duplicates for VOC analysis. }\end{array}$ \\
\hline SSL-29 & $7 / 12 / 00$ & $\begin{array}{l}\text { N } 88405 \\
\text { E } 48425\end{array}$ & $\begin{array}{l}\text { South of location SSL-30 } 650 \text { feet. Evidence of stream } \\
\text { braiding. }\end{array}$ & $15 \mathrm{ft}-3$ in & 70 in & $8 \mathrm{ft}-2$ in & Collected eight (8) sediment samples with duplicates for VOC analysis. \\
\hline SSL-30 & $7 / 12 / 00$ & $\begin{array}{l}\text { N } 89042 \\
\text { E } 48497\end{array}$ & $\begin{array}{l}\text { Location south of power line crossing. Decrease in slop } \\
\text { associated with valley walls. Meandering stream. }\end{array}$ & $15 \mathrm{ft}-1 \mathrm{in}$ & 50 in & $10 \mathrm{ft}-6 \mathrm{in}$ & $\begin{array}{l}\text { Collected eleven (11) sediment samples with duplicates for VOC } \\
\text { analysis. }\end{array}$ \\
\hline SSL-31 & $8 / 14 / 00$ & $\begin{array}{l}\text { N } 93315 \\
\text { E } 50570\end{array}$ & (Same location as SSL-13.) & $12 \mathrm{ft}-0$ in & 82 in & $4 \mathrm{ft}-6$ in & Collected five (5) sediment samples with duplicates for VOC analysis. \\
\hline SSL-32 & $8 / 14 / 00$ & $\begin{array}{l}\text { N } 93461 \\
\text { E } 50916\end{array}$ & (Same location as SSL-19.) & $11 \mathrm{ft}-3$ in & 80 in & $4 \mathrm{ft}-7$ in & Collected five (5) sediment samples with duplicates for VOC analysis. \\
\hline
\end{tabular}


(This Page Intentionally Blank) 
Lost Lake Outcrop Zone

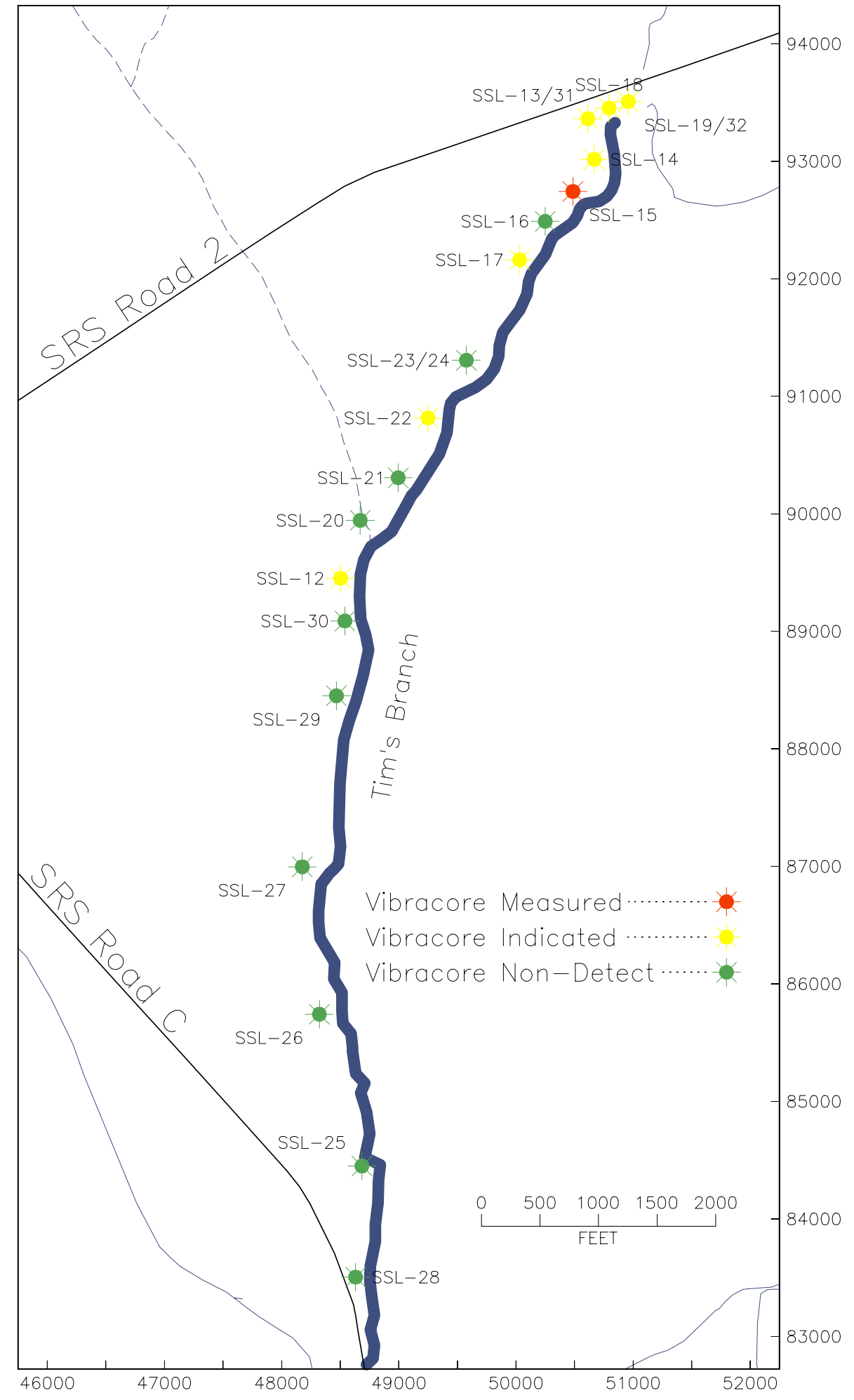

Figure 5: Location of Vibracores that were Collected along Seepline Between SRS Road 2 and SRS Road C. 
Table 3: Depth Discrete Soil-Plug Concentrations associated with Boring SSL-12 collected on July 6, 2000 along Tims Branch Seepline.

\begin{tabular}{|c|c|c|c|c|c|c|c|c|c|c|}
\hline \multicolumn{3}{|c|}{ Average of Soil (ug/g) } & \multirow{2}{*}{\begin{tabular}{|r|} 
Analyte \\
PCE
\end{tabular}} & \multirow{2}{*}{ TCE } & \multirow[b]{2}{*}{ C-DCE } & \multirow[b]{2}{*}{ T-DCE } & \multirow[b]{2}{*}{ 11DCE } & \multirow[b]{2}{*}{ CHCL3 } & \multirow[b]{2}{*}{ CCL4 } & \multirow[b]{2}{*}{ TCA } \\
\hline Sample ID & Detector & Sample & & & & & & & & \\
\hline \multirow[t]{2}{*}{ SSL-12-01 } & ECD2 & $\# 1$ & Trace & ND & ND & ND & ND & ND & ND & ND \\
\hline & & \#2 & ND & ND & ND & ND & ND & ND & ND & ND \\
\hline \multirow[t]{2}{*}{ SSL-12-02 } & ECD2 & \#1 & ND & Trace & ND & ND & ND & ND & ND & ND \\
\hline & & \#2 & ND & Trace & ND & ND & ND & ND & ND & ND \\
\hline \multirow[t]{2}{*}{ SSL-12-03 } & ECD2 & $\# 1$ & (Invalid) & (Invalid) & (Invalid) & (Invalid) & (Invalid) & (Invalid) & $\overline{\text { (Invalid) }}$ & (Invalid) \\
\hline & & \#2 & ND & ND & ND & ND & ND & ND & ND & ND \\
\hline \multirow[t]{2}{*}{ SSL-12-04 } & ECD2 & $\# 1$ & ND & ND & ND & ND & ND & ND & ND & ND \\
\hline & & \#2 & ND & ND & ND & ND & ND & ND & ND & ND \\
\hline \multirow[t]{2}{*}{ SSL-12-05 } & ECD2 & $\# 1$ & ND & Trace & $\overline{N D}$ & ND & ND & ND & ND & ND \\
\hline & & \#2 & ND & Trace & ND & ND & ND & ND & ND & ND \\
\hline \multirow[t]{2}{*}{ SSL-12-06 } & ECD2 & $\# 1$ & ND & Trace & $\overline{N D}$ & ND & ND & $\overline{N D}$ & ND & $\overline{N D}$ \\
\hline & & \#2 & ND & Trace & ND & ND & ND & ND & ND & ND \\
\hline
\end{tabular}

Table 4: $\quad$ Depth Discrete Soil-Plug Concentrations associated with Boring SSL-13 collected on July 6, 2000 along Tims Branch Seepline.

\begin{tabular}{|l|l|l|l|lcccccc|}
\hline Average of Soil (ug/g) & Analyte & & & & & & \\
\hline Sample ID & Detector & Sample & PCE & TCE & C-DCE & T-DCE & 11DCE & CHCL3 & CCL4 & TCA \\
\hline SSL-13-01 & ECD2 & $\# 1$ & (Invalid) & (Invalid) & (Invalid) & (Invalid) & (Invalid) & (Invalid) & (Invalid) & (Invalid) \\
& & $\# 2$ & ND & ND & ND & ND & ND & ND & ND & ND \\
\hline SSL-13-02 & ECD2 & $\# 1$ & ND & Trace & ND & ND & ND & ND & ND & ND \\
& & $\# 2$ & ND & Trace & ND & ND & ND & ND & ND & ND \\
\hline SSL-13-03 ECD2 & $\# 1$ & ND & Trace & ND & ND & ND & ND & ND & ND \\
& & $\# 2$ & ND & Trace & ND & ND & ND & ND & ND & ND \\
\hline SSL-13-04 ECD2 & $\# 1$ & ND & Trace & ND & ND & ND & Trace & ND & ND \\
& & $\# 2$ & ND & Trace & ND & ND & ND & ND & ND & ND \\
\hline SSL-13-05 ECD2 & $\# 1$ & Trace & Trace & ND & ND & ND & ND & ND & ND \\
& & $\# 2$ & Trace & Trace & ND & ND & ND & ND & ND & ND \\
\hline SSL-13-06 ECD2 & $\# 1$ & Trace & Trace & ND & ND & ND & ND & ND & ND \\
& & $\# 2$ & Trace & Trace & ND & ND & ND & ND & ND & ND \\
\hline
\end{tabular}


Table 5: Depth Discrete Soil-Plug Concentrations associated with Boring SSL-14 collected on July 6, 2000 along Tims Branch Seepline.

\begin{tabular}{|c|c|c|c|c|c|c|c|c|c|c|}
\hline \multicolumn{3}{|c|}{ Average of Soil (ug/g) } & Analyte & 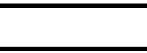 & \multirow{2}{*}{ C-DCE } & \multirow{2}{*}{ T-DCE } & \multirow{2}{*}{ 11DCE } & \multirow{2}{*}{$\mathrm{CHCL3}$} & \multirow{2}{*}{ CCL4 } & \multirow[b]{2}{*}{$\overline{T C A}$} \\
\hline Sample ID & Detector & Sample & PCE & TCE & & & & & & \\
\hline \multirow{2}{*}{ SSL-14-01 } & ECD2 & $\# 1$ & ND & ND & ND & ND & ND & ND & ND & ND \\
\hline & & \#2 & ND & ND & ND & ND & ND & ND & ND & ND \\
\hline \multirow[t]{2}{*}{ SSL-14-02 } & ECD2 & \#1 & ND & ND & $\overline{N D}$ & ND & ND & ND & ND & ND \\
\hline & & \#2 & ND & ND & ND & ND & ND & ND & ND & ND \\
\hline \multirow[t]{2}{*}{ SSL-14-03 } & ECD2 & $\# 1$ & Trace & Trace & ND & ND & ND & ND & ND & ND \\
\hline & & \#2 & Trace & Trace & ND & ND & ND & ND & Trace & ND \\
\hline \multirow[t]{2}{*}{ SSL-14-04 } & ECD2 & \#1 & Trace & Trace & $\overline{N D}$ & $\overline{N D}$ & $\overline{N D}$ & $\overline{N D}$ & ND & $\overline{N D}$ \\
\hline & & \#2 & (Invalid) & (Invalid) & (Invalid) & (Invalid) & (Invalid) & (Invalid) & (Invalid) & (Invalid) \\
\hline \multirow[t]{2}{*}{ SSL-14-05 } & ECD2 & $\# 1$ & (Invalid) & (Invalid) & (Invalid) & (Invalid) & (Invalid) & (Invalid) & (Invalid) & (Invalid) \\
\hline & & \#2 & Trace & Trace & ND & ND & ND & ND & ND & ND \\
\hline \multirow[t]{2}{*}{ SSL-14-06 } & ECD2 & $\# 1$ & Trace & Trace & $\overline{N D}$ & ND & ND & $\overline{N D}$ & ND & $\overline{N D}$ \\
\hline & & \#2 & Trace & Trace & ND & ND & ND & ND & ND & ND \\
\hline \multirow[t]{2}{*}{ SSL-14-07 } & ECD2 & $\# 1$ & Trace & Trace & ND & $\overline{N D}$ & ND & ND & ND & ND \\
\hline & & \#2 & Trace & Trace & ND & ND & ND & ND & ND & ND \\
\hline
\end{tabular}

Table 6: $\quad$ Depth Discrete Soil-Plug Concentrations associated with Boring SSL-15 collected on July 6, 2000 along Tims Branch Seepline.

\begin{tabular}{|c|c|c|c|c|c|c|c|c|c|c|}
\hline \multicolumn{3}{|c|}{ Average of Soil (ug/g) } & \multicolumn{8}{|l|}{ Analyte } \\
\hline Sample ID & Detector & Sample & PCE & TCE & C-DCE & T-DCE & 11DCE & CHCL3 & CCL4 & TCA \\
\hline \multirow[t]{2}{*}{ SSL-15-01 } & ECD2 & $\# 1$ & $\overline{N D}$ & $\overline{N D}$ & ND & $\overline{N D}$ & ND & $\overline{N D}$ & $\overline{N D}$ & $\overline{N D}$ \\
\hline & & \#2 & ND & ND & ND & ND & ND & ND & ND & ND \\
\hline \multirow[t]{2}{*}{ SSL-15-02 } & ECD2 & $\# 1$ & (Invalid) & (Invalid) & (Invalid) & $\overline{\text { (Invalid) }}$ & (Invalid) & (Invalid) & $\begin{array}{l}\text { (Invalid) } \\
\text { Int }\end{array}$ & (Invalid) \\
\hline & & \#2 & Trace & .014 & ND & ND & ND & ND & Trace & ND \\
\hline \multirow[t]{2}{*}{ SSL-15-03 } & ECD2 & $\# 1$ & $\overline{N D}$ & ND & ND & $\overline{N D}$ & ND & $\overline{N D}$ & ND & $\overline{N D}$ \\
\hline & & \#2 & ND & ND & ND & ND & ND & ND & ND & ND \\
\hline \multirow[t]{2}{*}{ SSL-15-04 } & ECD2 & $\# 1$ & $\overline{N D}$ & ND & ND & $\overline{N D}$ & ND & ND & ND & ND \\
\hline & & \#2 & (Invalid) & (Invalid) & (Invalid) & (Invalid) & (Invalid) & (Invalid) & (Invalid) & (Invalid) \\
\hline \multirow[t]{2}{*}{ SSL-15-05 } & ECD2 & $\# 1$ & (Invalid) & (Invalid) & (Invalid) & (Invalid) & (Invalid) & (Invalid) & (Invalid) & (Invalid) \\
\hline & & \#2 & ND & ND & ND & ND & ND & ND & ND & ND \\
\hline \multirow{2}{*}{ SSL-15-06 } & ECD2 & $\# 1$ & $\overline{\mathrm{ND}}$ & $\overline{N D}$ & $\overline{N D}$ & $\overline{N D}$ & $\overline{N D}$ & $\overline{N D}$ & $\overline{N D}$ & $\overline{N D}$ \\
\hline & & \#2 & ND & ND & ND & ND & ND & ND & ND & ND \\
\hline
\end{tabular}


Table 7: Depth Discrete Soil-Plug Concentrations associated with Boring SSL-16 collected on July 7, 2000 along Tims Branch Seepline.

\begin{tabular}{|c|c|c|c|c|c|c|c|c|c|c|}
\hline \multicolumn{3}{|c|}{ Average of Soil (ug/g) } & \multicolumn{8}{|l|}{ Analyte } \\
\hline Sample ID & Detector & Sample & PCE & TCE & C-DCE & T-DCE & 11DCE & CHCL3 & CCL4 & TCA \\
\hline \multirow[t]{2}{*}{ SSL-16-01 } & ECD2 & $\# 1$ & $\overline{N D}$ & ND & ND & ND & ND & ND & ND & ND \\
\hline & & \#2 & ND & ND & ND & ND & ND & ND & ND & ND \\
\hline \multirow[t]{2}{*}{ SSL-16-02 } & ECD2 & $\# 1$ & ND & ND & ND & ND & ND & $\overline{N D}$ & ND & ND \\
\hline & & \#2 & ND & ND & ND & ND & ND & ND & ND & ND \\
\hline \multirow{2}{*}{ SSL-16-03 } & ECD2 & $\# 1$ & ND & ND & $\overline{N D}$ & $\overline{N D}$ & $\overline{N D}$ & $\overline{N D}$ & $\overline{N D}$ & ND \\
\hline & & \#2 & ND & ND & ND & ND & ND & ND & ND & ND \\
\hline \multirow[t]{2}{*}{ SSL-16-04 } & ECD2 & $\# 1$ & ND & ND & ND & ND & $\overline{N D}$ & $\overline{N D}$ & $\overline{N D}$ & ND \\
\hline & & \#2 & ND & ND & ND & ND & ND & ND & ND & ND \\
\hline \multirow[t]{2}{*}{ SSL-16-05 } & ECD2 & $\# 1$ & $\overline{N D}$ & ND & $\overline{N D}$ & $\overline{N D}$ & ND & $\overline{N D}$ & $\overline{N D}$ & ND \\
\hline & & \#2 & ND & ND & ND & ND & ND & ND & ND & ND \\
\hline \multirow[t]{2}{*}{$\overline{S S L-16-06}$} & ECD2 & $\# 1$ & $\overline{N D}$ & ND & ND & $\overline{N D}$ & ND & $\overline{N D}$ & $\overline{N D}$ & ND \\
\hline & & \#2 & ND & ND & ND & ND & ND & ND & ND & ND \\
\hline \multirow[t]{2}{*}{ SSL-16-07 } & ECD2 & $\# 1$ & $\overline{N D}$ & ND & $\overline{N D}$ & $\overline{N D}$ & ND & $\overline{N D}$ & $\overline{N D}$ & $\overline{N D}$ \\
\hline & & \#2 & ND & ND & ND & ND & ND & ND & ND & ND \\
\hline \multirow[t]{2}{*}{$\overline{\text { SSL-16-08 }}$} & ECD2 & $\# 1$ & ND & ND & ND & ND & ND & ND & ND & ND \\
\hline & & \#2 & ND & ND & ND & ND & ND & ND & ND & ND \\
\hline
\end{tabular}

Table 8: Depth Discrete Soil-Plug Concentrations associated with Boring SSL-17 collected on July 7, 2000 along Tims Branch Seepline.

\begin{tabular}{|c|c|c|c|c|c|c|c|c|c|c|}
\hline Average of & f Soil (ug/g & & Analyte & & & & & & & \\
\hline Sample ID & Detector & Sample & PCE & TCE & C-DCE & T-DCE & 11DCE & CHCL3 & CCL4 & TCA \\
\hline SSL-17-01 & ECD2 & $\# 1$ & ND & ND & ND & ND & ND & ND & ND & ND \\
\hline & & \#2 & Trace & Trace & ND & ND & ND & ND & Trace & ND \\
\hline SSL-17-02 & ECD2 & \#1 & ND & ND & ND & ND & ND & ND & ND & ND \\
\hline & & \#2 & ND & ND & ND & ND & ND & ND & ND & ND \\
\hline SSL-17-03 & ECD2 & $\# 1$ & (Invalid) & (Invalid) & (Invalid) & (Invalid) & (Invalid) & (Invalid) & (Invalid) & $\overline{\text { (Invalid) }}$ \\
\hline & & \#2 & Trace & Trace & ND & ND & ND & ND & ND & ND \\
\hline SSL-17-04 & ECD2 & $\# 1$ & Trace & ND & ND & ND & ND & ND & ND & ND \\
\hline & & \#2 & ND & ND & ND & ND & ND & ND & ND & ND \\
\hline SSL-17-05 & ECD2 & \#1 & Trace & Trace & ND & ND & ND & ND & ND & ND \\
\hline & & \#2 & (Invalid) & (Invalid) & (Invalid) & (Invalid) & (Invalid) & (Invalid) & (Invalid) & (Invalid) \\
\hline SSL-17-06 & ECD2 & \#1 & Trace & Trace & ND & ND & ND & ND & ND & ND \\
\hline & & \#2 & Trace & Trace & ND & ND & ND & ND & ND & ND \\
\hline SSL-17-07 & ECD2 & $\# 1$ & (Invalid) & (Invalid) & (Invalid) & (Invalid) & (Invalid) & (Invalid) & (Invalid) & (Invalid) \\
\hline & & \#2 & Trace & Trace & ND & ND & ND & ND & ND & ND \\
\hline SSL-17-08 & ECD2 & $\# 1$ & Trace & Trace & ND & ND & ND & ND & ND & ND \\
\hline & & \#2 & Trace & Trace & ND & ND & ND & ND & ND & ND \\
\hline
\end{tabular}


Table 9: $\quad$ Depth Discrete Soil-Plug Concentrations associated with Boring SSL-18 collected on July 7, 2000 along Tims Branch Seepline.

\begin{tabular}{|c|c|c|c|c|c|c|c|c|c|c|}
\hline Average of & f Soil (ug/s & & Analyte & & & & & & & \\
\hline Sample ID & Detector & Sample & PCE & TCE & C-DCE & T-DCE & 11DCE & CHCL3 & CCL4 & TCA \\
\hline SSL-18-01 & ECD2 & $\begin{array}{l}\# 1 \\
\# 2\end{array}$ & $\begin{array}{c}\text { (Invalid) } \\
\text { Trace }\end{array}$ & $\begin{array}{c}\text { (Invalid) } \\
\text { Trace }\end{array}$ & $\begin{array}{c}\text { (Invalid) } \\
\text { ND }\end{array}$ & $\begin{array}{c}\text { (Invalid) } \\
\text { ND }\end{array}$ & $\begin{array}{c}\text { (Invalid) } \\
\text { ND }\end{array}$ & $\begin{array}{c}\text { (Invalid) } \\
\text { ND }\end{array}$ & $\begin{array}{c}\text { (Invalid) } \\
\text { ND }\end{array}$ & $\begin{array}{c}\text { (Invalid) } \\
\text { ND }\end{array}$ \\
\hline-02 & ECD2 & $\begin{array}{l}\# 1 \\
\# 2 \\
\end{array}$ & $\begin{array}{l}\text { Trace } \\
\text { Trace } \\
\end{array}$ & $\begin{array}{l}\text { Trace } \\
\text { Trace } \\
\end{array}$ & $\begin{array}{l}\mathrm{ND} \\
\mathrm{ND} \\
\end{array}$ & $\begin{array}{l}\text { ND } \\
\text { ND } \\
\end{array}$ & $\begin{array}{l}\mathrm{ND} \\
\mathrm{ND} \\
\end{array}$ & $\begin{array}{l}\mathrm{ND} \\
\mathrm{ND} \\
\end{array}$ & $\begin{array}{l}\mathrm{ND} \\
\mathrm{ND} \\
\end{array}$ & $\begin{array}{l}\text { ND } \\
\text { ND } \\
\end{array}$ \\
\hline
\end{tabular}

Table 10: Depth Discrete Soil-Plug Concentrations associated with Boring SSL-20 collected on July 10, 2000 along Tims Branch Seepline.

\begin{tabular}{|c|c|c|c|c|c|c|c|c|c|c|}
\hline Average of & f Soil (ug/g & & Analyte & & & & & & & \\
\hline Sample ID & Detector & Sample & PCE & TCE & C-DCE & T-DCE & 11DCE & CHCL3 & CCL4 & TCA \\
\hline SSL-20-01 & ECD2 & $\# 1$ & ND & ND & ND & ND & ND & ND & ND & ND \\
\hline & & \#2 & ND & ND & ND & ND & ND & ND & ND & ND \\
\hline SSL-20-02 & ECD2 & \#1 & ND & ND & ND & ND & ND & ND & ND & ND \\
\hline & & \#2 & ND & ND & ND & ND & ND & ND & ND & ND \\
\hline SSL-20-03 & ECD2 & $\# 1$ & ND & ND & ND & $\overline{N D}$ & ND & ND & ND & ND \\
\hline & & \#2 & ND & ND & ND & ND & ND & ND & ND & ND \\
\hline SSL-20-04 & ECD2 & $\# 1$ & ND & ND & ND & $\overline{N D}$ & ND & $\overline{N D}$ & ND & ND \\
\hline & & \#2 & ND & ND & ND & ND & ND & ND & ND & ND \\
\hline SSL-20-05 & ECD2 & \#1 & $\overline{\text { (Invalid) }}$ & (Invalid) & (Invalid) & (Invalid) & (Invalid) & (Invalid) & (Invalid) & (Invalid) \\
\hline & & \#2 & ND & ND & ND & ND & ND & ND & ND & ND \\
\hline SSL-20-06 & ECD2 & $\# 1$ & ND & ND & ND & ND & ND & ND & ND & ND \\
\hline & & \#2 & (Invalid) & (Invalid) & (Invalid) & (Invalid) & (Invalid) & (Invalid) & (Invalid) & (Invalid) \\
\hline SSL-20-07 & ECD2 & \#1 & ND & ND & ND & ND & ND & ND & ND & ND \\
\hline & & \#2 & (Invalid) & (Invalid) & (Invalid) & (Invalid) & (Invalid) & (Invalid) & (Invalid) & (Invalid) \\
\hline SSL-20-08 & ECD2 & $\# 1$ & ND & Trace & ND & ND & ND & ND & ND & ND \\
\hline & & \#2 & ND & ND & ND & ND & ND & ND & ND & ND \\
\hline SSL-20-09 & ECD2 & $\# 1$ & $\overline{N D}$ & Trace & $\overline{N D}$ & $\overline{N D}$ & $\overline{N D}$ & $\overline{N D}$ & $\overline{N D}$ & $\overline{N D}$ \\
\hline & & \#2 & ND & ND & ND & ND & ND & ND & ND & ND \\
\hline
\end{tabular}


Table 11: Depth Discrete Soil-Plug Concentrations associated with Boring SSL-21 collected on July 10, 2000 along Tims Branch Seepline.

\begin{tabular}{|c|c|c|c|c|c|c|c|c|c|c|}
\hline \multicolumn{3}{|c|}{ Average of Soil (ug/g) } & Analyte & \multirow[b]{2}{*}{ TCE } & \multirow[b]{2}{*}{ C-DCE } & \multirow[b]{2}{*}{ T-DCE } & \multirow[b]{2}{*}{ 11DCE } & \multirow[b]{2}{*}{ CHCL3 } & \multirow[b]{2}{*}{ CCL4 } & \multirow[b]{2}{*}{ TCA } \\
\hline Sample ID & Detector & Sample & PCE & & & & & & & \\
\hline \multirow{2}{*}{ SSL-21-01 } & ECD2 & $\# 1$ & ND & ND & ND & ND & ND & ND & ND & ND \\
\hline & & \#2 & ND & ND & ND & ND & ND & ND & ND & ND \\
\hline \multirow[t]{2}{*}{ SSL-21-02 } & ECD2 & $\# 1$ & ND & ND & ND & ND & ND & ND & ND & ND \\
\hline & & \#2 & ND & ND & ND & ND & ND & ND & ND & ND \\
\hline \multirow[t]{2}{*}{$\widehat{S S L-21-03}$} & ECD2 & $\# 1$ & $\overline{N D}$ & $\overline{N D}$ & $\overline{N D}$ & $\overline{N D}$ & $\overline{N D}$ & $\overline{N D}$ & $\overline{N D}$ & ND \\
\hline & & \#2 & ND & ND & ND & ND & ND & ND & ND & ND \\
\hline \multirow[t]{2}{*}{$\widehat{S S L-21-04}$} & ECD2 & $\# 1$ & ND & ND & ND & ND & ND & ND & ND & ND \\
\hline & & \#2 & ND & ND & ND & ND & ND & ND & ND & ND \\
\hline \multirow[t]{2}{*}{ SSL-21-05 } & ECD2 & $\overline{\# 1}$ & $\overline{N D}$ & ND & ND & ND & ND & $\overline{N D}$ & ND & ND \\
\hline & & \#2 & ND & ND & ND & ND & ND & ND & ND & ND \\
\hline \multirow[t]{2}{*}{ SSL-21-07 } & ECD2 & $\# 1$ & $\overline{N D}$ & ND & ND & ND & ND & ND & ND & ND \\
\hline & & \#2 & ND & ND & ND & ND & ND & ND & ND & ND \\
\hline \multirow[t]{2}{*}{ SSL-21-08 } & ECD2 & $\# 1$ & ND & ND & ND & $\overline{N D}$ & ND & ND & $\overline{N D}$ & ND \\
\hline & & \#2 & ND & ND & ND & ND & ND & ND & ND & ND \\
\hline \multirow[t]{2}{*}{ SSL-21-09 } & ECD2 & $\# 1$ & ND & ND & ND & ND & ND & ND & ND & ND \\
\hline & & \#2 & ND & Trace & ND & ND & ND & ND & ND & ND \\
\hline
\end{tabular}

Table 12: Depth Discrete Soil-Plug Concentrations associated with Boring SSL-22 collected on July 10, 2000 along Tims Branch Seepline.

\begin{tabular}{|c|c|c|c|c|c|c|c|c|c|c|}
\hline \multicolumn{3}{|c|}{ Average of Soil (ug/g) } & \multicolumn{8}{|l|}{ Analyte } \\
\hline Sample ID & Detector & Sample & PCE & TCE & C-DCE & T-DCE & 11DCE & CHCL3 & CCL4 & TCA \\
\hline \multirow[t]{2}{*}{ SSL-22-01 } & ECD2 & $\# 1$ & ND & ND & ND & ND & ND & $\overline{N D}$ & ND & ND \\
\hline & & \#2 & ND & ND & ND & ND & ND & ND & ND & ND \\
\hline \multirow[t]{2}{*}{ SSL-22-02 } & ECD2 & $\# 1$ & ND & ND & ND & ND & ND & ND & ND & ND \\
\hline & & \#2 & ND & ND & ND & ND & ND & ND & ND & ND \\
\hline \multirow[t]{2}{*}{ SSL-22-03 } & ECD2 & \#1 & ND & $\overline{N D}$ & $\overline{N D}$ & ND & ND & ND & ND & ND \\
\hline & & \#2 & ND & ND & ND & ND & ND & ND & ND & ND \\
\hline \multirow[t]{2}{*}{ SSL-22-04 } & ECD2 & $\# 1$ & ND & $\overline{N D}$ & $\overline{N D}$ & ND & ND & $\overline{N D}$ & ND & ND \\
\hline & & \#2 & ND & ND & ND & ND & ND & ND & ND & ND \\
\hline \multirow{2}{*}{ SSL-22-05 } & ECD2 & $\# 1$ & $\overline{N D}$ & Trace & $\overline{N D}$ & $\overline{N D}$ & ND & $\overline{N D}$ & $\overline{N D}$ & ND \\
\hline & & \#2 & ND & Trace & ND & ND & ND & ND & ND & ND \\
\hline \multirow[t]{2}{*}{ SSL-22-06 } & ECD2 & $\# 1$ & ND & Trace & ND & $\overline{N D}$ & ND & $\overline{N D}$ & $\overline{N D}$ & ND \\
\hline & & \#2 & Trace & Trace & ND & ND & ND & ND & ND & ND \\
\hline \multirow[t]{2}{*}{ SSL-22-07 } & ECD2 & \#1 & ND & ND & ND & ND & ND & ND & ND & ND \\
\hline & & \#2 & ND & ND & ND & ND & ND & ND & ND & ND \\
\hline \multirow[t]{2}{*}{ SSL-22-08 } & ECD2 & $\# 1$ & $\overline{N D}$ & Trace & $\overline{N D}$ & $\overline{N D}$ & ND & $\overline{N D}$ & $\overline{N D}$ & ND \\
\hline & & \#2 & ND & ND & ND & ND & ND & ND & ND & ND \\
\hline
\end{tabular}


WSRC-TR-2000-00472

Table 13: Depth Discrete Soil-Plug Concentrations associated with Boring SSL-23 collected on July 10, 2000 along Tims Branch Seepline.

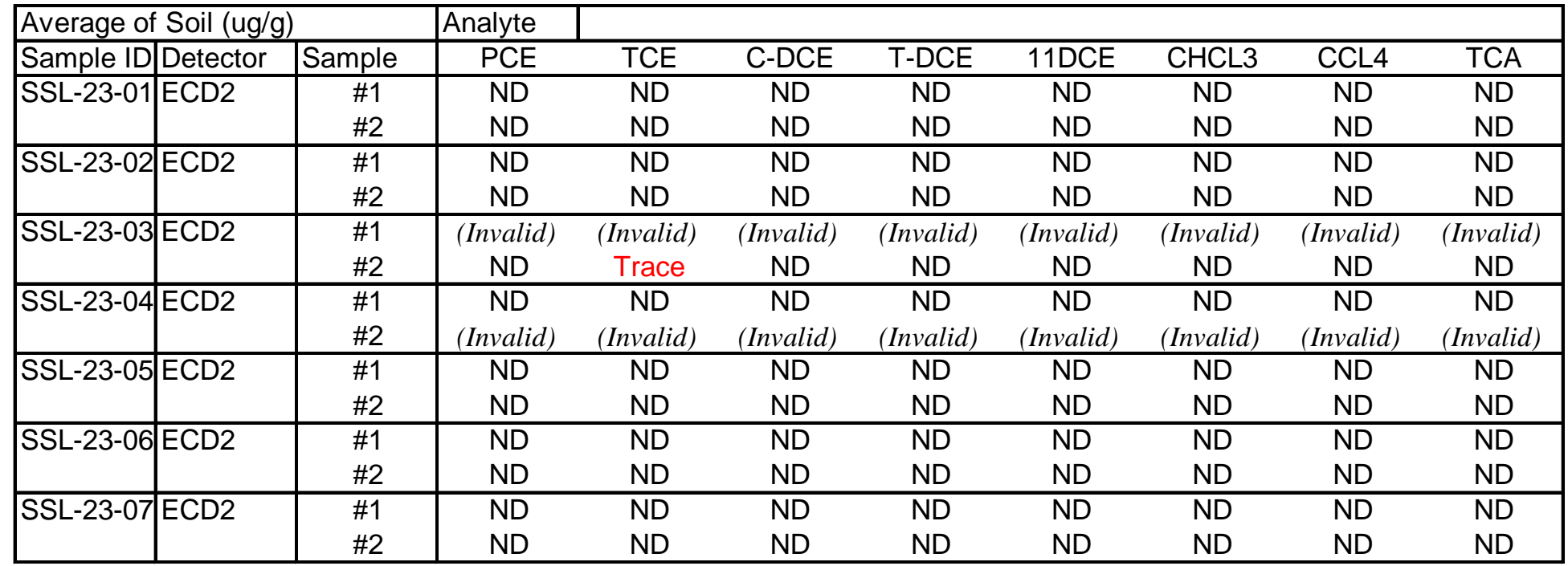

Table 14: Depth Discrete Soil-Plug Concentrations associated with Boring SSL-24 collected on July 10, 2000 along Tims Branch Seepline.

\begin{tabular}{|c|c|c|c|c|c|c|c|c|c|c|}
\hline Average of & f Soil (ug/s & & Analyte & & & & & & & \\
\hline Sample ID & Detector & Sample & PCE & TCE & C-DCE & T-DCE & 11DCE & CHCL3 & CCL4 & TCA \\
\hline SSL-24-01 & ECD2 & $\# 1$ & $\overline{N D}$ & ND & ND & $\overline{N D}$ & $\overline{N D}$ & ND & ND & $\overline{N D}$ \\
\hline & & \#2 & ND & ND & ND & ND & ND & ND & ND & ND \\
\hline SSL-24-02 & ECD2 & \#1 & ND & ND & ND & ND & ND & ND & ND & ND \\
\hline & & \#2 & ND & ND & ND & ND & ND & ND & ND & ND \\
\hline SSL-24-03 & ECD2 & $\# 1$ & ND & ND & ND & ND & ND & ND & ND & ND \\
\hline & & \#2 & ND & ND & ND & ND & ND & ND & ND & ND \\
\hline SSL-24-04 & ECD2 & $\# 1$ & ND & $\overline{N D}$ & ND & ND & ND & ND & ND & $\overline{N D}$ \\
\hline & & \#2 & ND & ND & ND & ND & ND & ND & ND & ND \\
\hline SSL-24-05 & ECD2 & $\# 1$ & $\overline{N D}$ & ND & ND & ND & ND & ND & ND & ND \\
\hline & & \#2 & ND & ND & ND & ND & ND & ND & ND & ND \\
\hline SSL-24-06 & ECD2 & $\# 1$ & $\overline{N D}$ & $\overline{N D}$ & $\overline{N D}$ & $\overline{N D}$ & $\overline{N D}$ & $\overline{N D}$ & $\overline{N D}$ & ND \\
\hline & & \#2 & ND & ND & ND & ND & ND & ND & ND & ND \\
\hline SSL-24-07 & ECD2 & $\# 1$ & (Invalid) & (Invalid) & (Invalid) & (Invalid) & (Invalid) & (Invalid) & (Invalid) & (Invalid) \\
\hline & & $\# 2$ & ND & ND & ND & ND & ND & ND & ND & ND \\
\hline SSL-24-08 & ECD2 & $\# 1$ & $\overline{N D}$ & $\overline{N D}$ & $\overline{N D}$ & $\overline{N D}$ & $\overline{N D}$ & $\overline{N D}$ & $\overline{N D}$ & ND \\
\hline & & \#2 & ND & ND & ND & ND & ND & ND & ND & ND \\
\hline SSL-24-09 & ECD2 & \#1 & ND & ND & ND & ND & ND & ND & ND & ND \\
\hline & & \#2 & ND & ND & ND & ND & ND & ND & ND & ND \\
\hline SSL-24-10 & ECD2 & $\# 1$ & ND & ND & ND & ND & ND & ND & ND & ND \\
\hline & & \#2 & ND & ND & ND & ND & ND & ND & ND & ND \\
\hline SSL-24-11 & ECD2 & $\# 1$ & ND & ND & $\overline{N D}$ & $\overline{N D}$ & ND & $\overline{N D}$ & ND & ND \\
\hline & & \#2 & ND & ND & ND & ND & ND & ND & ND & ND \\
\hline
\end{tabular}


Table 15: Depth Discrete Soil-Plug Concentrations associated with Boring SSL-25 collected on July 11, 2000 along Tims Branch Seepline.

\begin{tabular}{|c|c|c|c|c|c|c|c|c|c|c|}
\hline Average of & Soil & & Analyte & & & & & & & \\
\hline Sample ID & Detector & Sample & PCE & TCE & C-DCE & T-DCE & 11DCE & CHCL3 & CCL4 & TCA \\
\hline SSL-25-01 & ECD2 & \#1 & ND & ND & ND & ND & ND & ND & ND & ND \\
\hline & & \#2 & ND & ND & ND & ND & ND & ND & ND & ND \\
\hline SSL-25-02 & ECD2 & \#1 & ND & ND & ND & ND & ND & ND & ND & ND \\
\hline & & $\# 2$ & ND & ND & ND & ND & ND & ND & ND & ND \\
\hline SSL-25-03 & ECD2 & $\# 1$ & ND & ND & ND & ND & ND & ND & ND & ND \\
\hline & & \#2 & ND & ND & ND & ND & ND & ND & ND & ND \\
\hline SSL-25-04 & ECD2 & $\# 1$ & ND & Trace & ND & ND & ND & ND & ND & ND \\
\hline & & \#2 & ND & ND & ND & ND & ND & ND & ND & ND \\
\hline SSL-25-05 & ECD2 & $\# 1$ & ND & ND & ND & ND & ND & ND & ND & ND \\
\hline & & \#2 & ND & ND & ND & ND & ND & ND & ND & ND \\
\hline SSL-25-06 & ECD2 & \#1 & ND & ND & ND & ND & ND & ND & ND & ND \\
\hline & & \#2 & ND & ND & ND & ND & ND & ND & ND & ND \\
\hline SSL-25-07 & ECD2 & $\# 1$ & $\overline{N D}$ & $\overline{N D}$ & $\overline{N D}$ & $\overline{N D}$ & $\overline{N D}$ & $\overline{N D}$ & ND & ND \\
\hline & & \#2 & ND & ND & ND & ND & ND & ND & ND & ND \\
\hline
\end{tabular}

Table 16: Depth Discrete Soil-Plug Concentrations associated with Boring SSL-26 collected on July 11, 2000 along Tims Branch Seepline.

\begin{tabular}{|c|c|c|c|c|c|c|c|c|c|c|}
\hline Average of & Soil & & Analyte & & & & & & & \\
\hline Sample ID & Detector & Sample & PCE & TCE & C-DCE & T-DCE & 11DCE & CHCL3 & CCL4 & TCA \\
\hline SSL-26-01 & ECD2 & $\# 1$ & ND & ND & ND & ND & ND & ND & ND & ND \\
\hline & & \#2 & ND & ND & ND & ND & ND & ND & ND & ND \\
\hline SSL-26-02 & ECD2 & $\# 1$ & ND & ND & ND & ND & ND & ND & ND & ND \\
\hline & & \#2 & ND & ND & ND & ND & ND & ND & ND & ND \\
\hline SSL-26-03 & ECD2 & \#1 & ND & ND & ND & ND & ND & ND & ND & ND \\
\hline & & \#2 & ND & ND & ND & ND & ND & ND & ND & ND \\
\hline SSL-26-04 & ECD2 & \#1 & ND & ND & ND & ND & ND & ND & ND & ND \\
\hline & & \#2 & ND & ND & ND & ND & ND & ND & ND & ND \\
\hline SSL-26-05 & ECD2 & \#1 & ND & ND & ND & ND & ND & ND & ND & ND \\
\hline & & \#2 & ND & ND & ND & ND & ND & ND & ND & ND \\
\hline SSL-26-06 & ECD2 & \#1 & ND & Trace & ND & ND & ND & ND & ND & ND \\
\hline & & \#2 & ND & ND & ND & ND & ND & ND & ND & ND \\
\hline
\end{tabular}


Table 17: Depth Discrete Soil-Plug Concentrations associated with Boring SSL-27 collected on July 11, 2000 along Tims Branch Seepline.

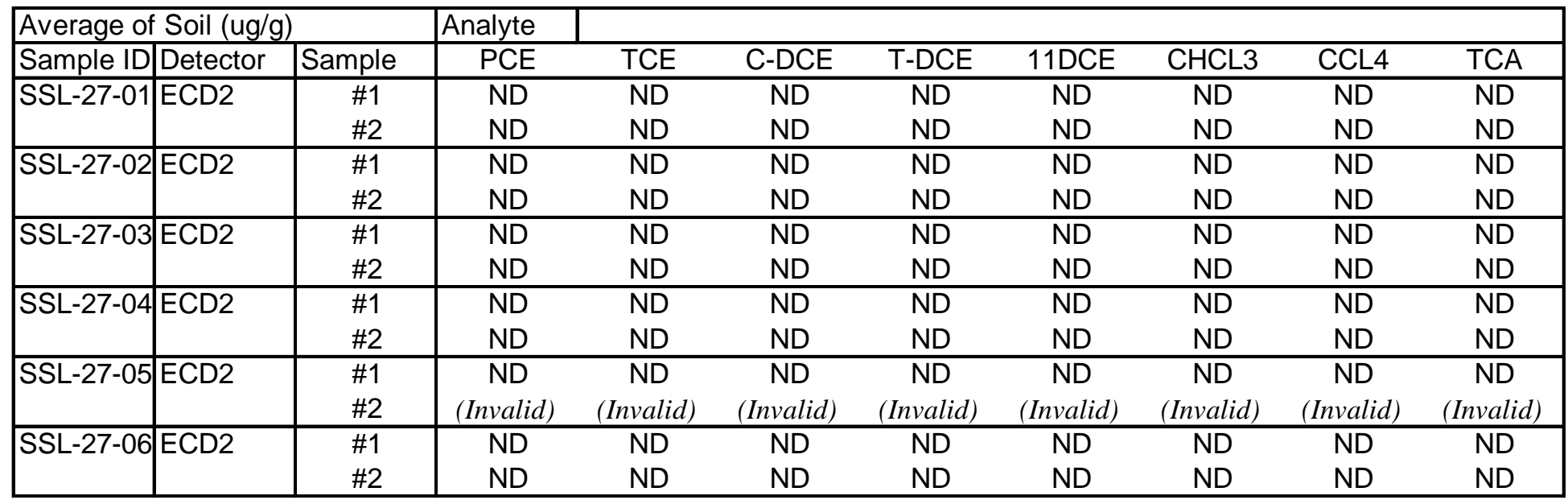

Table 18: Depth Discrete Soil-Plug Concentrations associated with Boring SSL-28 collected on July 11, 2000 along Tims Branch Seepline.

\begin{tabular}{|c|c|c|c|c|c|c|c|c|c|c|}
\hline Average of & Soil & & Analyte & & & & & & & \\
\hline Sample ID & Detector & Sample & PCE & TCE & C-DCE & T-DCE & 11DCE & CHCL3 & CCL4 & TCA \\
\hline SSL-28-01 & ECD2 & $\begin{array}{l}\# 1 \\
\# 2\end{array}$ & $\begin{array}{l}\text { ND } \\
\text { ND }\end{array}$ & $\begin{array}{l}\text { ND } \\
\text { ND }\end{array}$ & $\begin{array}{l}\text { ND } \\
\text { ND }\end{array}$ & $\begin{array}{l}\text { ND } \\
\text { ND }\end{array}$ & $\begin{array}{l}\text { ND } \\
\text { ND }\end{array}$ & $\begin{array}{l}\text { ND } \\
\text { ND }\end{array}$ & $\begin{array}{l}\text { ND } \\
\text { ND }\end{array}$ & $\begin{array}{l}\text { ND } \\
\text { ND }\end{array}$ \\
\hline SSL-28-02 & ECD2 & $\begin{array}{l}\# 1 \\
\# 2 \\
\end{array}$ & $\begin{array}{c}\text { (Invalid) } \\
\text { ND }\end{array}$ & $\begin{array}{c}\text { (Invalid) } \\
\text { ND }\end{array}$ & $\begin{array}{c}\text { (Invalid) } \\
\text { ND }\end{array}$ & $\begin{array}{c}\text { (Invalid) } \\
\text { ND }\end{array}$ & $\begin{array}{c}\text { (Invalid) } \\
\text { ND }\end{array}$ & $\begin{array}{c}\text { (Invalid) } \\
\text { ND }\end{array}$ & $\begin{array}{c}\text { (Invalid) } \\
\text { ND }\end{array}$ & $\begin{array}{c}\text { (Invalid) } \\
\text { ND }\end{array}$ \\
\hline SSL-28-03 & ECD2 & $\begin{array}{l}\# 1 \\
\# 2\end{array}$ & $\begin{array}{c}\text { Trace } \\
\text { ND }\end{array}$ & $\begin{array}{l}\text { Trace } \\
\text { ND }\end{array}$ & $\begin{array}{l}\text { ND } \\
\text { ND }\end{array}$ & $\begin{array}{l}\text { ND } \\
\text { ND }\end{array}$ & $\begin{array}{l}\text { ND } \\
\text { ND }\end{array}$ & $\begin{array}{l}\text { ND } \\
\text { ND }\end{array}$ & $\begin{array}{l}\text { ND } \\
\text { ND }\end{array}$ & $\begin{array}{l}\text { ND } \\
\text { ND }\end{array}$ \\
\hline SSL-28-04 & ECD2 & $\begin{array}{l}\# 1 \\
\# 2\end{array}$ & $\begin{array}{l}\text { ND } \\
\text { ND }\end{array}$ & $\begin{array}{l}\text { ND } \\
\text { ND }\end{array}$ & $\begin{array}{l}\text { ND } \\
\text { ND }\end{array}$ & $\begin{array}{l}\text { ND } \\
\text { ND }\end{array}$ & $\begin{array}{l}\text { ND } \\
\text { ND }\end{array}$ & $\begin{array}{l}\text { ND } \\
\text { ND }\end{array}$ & $\begin{array}{l}\text { ND } \\
\text { ND }\end{array}$ & $\begin{array}{l}\text { ND } \\
\text { ND }\end{array}$ \\
\hline SSL-28-05 & ECD2 & $\begin{array}{l}\# 1 \\
\# 2\end{array}$ & $\begin{array}{l}\text { ND } \\
\text { ND }\end{array}$ & $\begin{array}{l}\text { ND } \\
\text { ND }\end{array}$ & $\begin{array}{l}\text { ND } \\
\text { ND }\end{array}$ & $\begin{array}{l}\text { ND } \\
\text { ND }\end{array}$ & $\begin{array}{l}\text { ND } \\
\text { ND }\end{array}$ & $\begin{array}{l}\text { ND } \\
\text { ND }\end{array}$ & $\begin{array}{l}\text { ND } \\
\text { ND }\end{array}$ & $\begin{array}{l}\text { ND } \\
\text { ND }\end{array}$ \\
\hline SSL-28-06 & ECD2 & $\begin{array}{l}\# 1 \\
\# 2\end{array}$ & $\begin{array}{l}\text { ND } \\
\text { ND }\end{array}$ & $\begin{array}{l}\text { ND } \\
\text { ND }\end{array}$ & $\begin{array}{l}\text { ND } \\
\text { ND }\end{array}$ & $\begin{array}{l}\text { ND } \\
\text { ND }\end{array}$ & $\begin{array}{l}\text { ND } \\
\text { ND }\end{array}$ & $\begin{array}{l}\text { ND } \\
\text { ND }\end{array}$ & $\begin{array}{l}\text { ND } \\
\text { ND }\end{array}$ & $\begin{array}{l}\text { ND } \\
\text { ND }\end{array}$ \\
\hline SSL-28-07 & ECD2 & $\begin{array}{l}\# 1 \\
\# 2\end{array}$ & $\begin{array}{c}\text { (Invalid) } \\
\text { ND }\end{array}$ & $\begin{array}{c}\text { (Invalid) } \\
\text { ND }\end{array}$ & $\begin{array}{c}\text { (Invalid) } \\
\text { ND }\end{array}$ & $\begin{array}{c}\text { (Invalid) } \\
\text { ND }\end{array}$ & $\begin{array}{c}\text { (Invalid) } \\
\text { ND }\end{array}$ & $\begin{array}{c}\text { (Invalid) } \\
\text { ND }\end{array}$ & $\begin{array}{c}\text { (Invalid) } \\
\text { ND }\end{array}$ & $\begin{array}{c}\text { (Invalid) } \\
\text { ND }\end{array}$ \\
\hline
\end{tabular}


WSRC-TR-2000-00472

Table 19: Depth Discrete Soil-Plug Concentrations associated with Boring SSL-29 collected on July 12, 2000 along Tims Branch Seepline.

\begin{tabular}{|c|c|c|c|c|c|c|c|c|c|c|}
\hline \multicolumn{3}{|c|}{ Average of Soil (ug/g) } & \multirow{2}{*}{\begin{tabular}{|r|} 
Analyte \\
PCE
\end{tabular}} & \multirow{2}{*}{ TCE } & \multirow[b]{2}{*}{ C-DCE } & \multirow[b]{2}{*}{ T-DCE } & \multirow[b]{2}{*}{ 11DCE } & \multirow[b]{2}{*}{ CHCL3 } & \multirow[b]{2}{*}{ CCL4 } & \multirow[b]{2}{*}{ TCA } \\
\hline Sample ID & Detector & Sample & & & & & & & & \\
\hline \multirow[t]{2}{*}{ SSL-29-01 } & ECD2 & $\# 1$ & $\overline{N D}$ & ND & ND & ND & ND & ND & ND & ND \\
\hline & & \#2 & ND & ND & ND & ND & ND & ND & ND & ND \\
\hline \multirow[t]{2}{*}{ SSL-29-02 } & ECD2 & $\# 1$ & ND & ND & ND & ND & ND & ND & ND & ND \\
\hline & & \#2 & ND & ND & ND & ND & ND & ND & ND & ND \\
\hline \multirow[t]{2}{*}{ SSL-29-03 } & ECD2 & $\# 1$ & ND & ND & ND & ND & ND & ND & ND & ND \\
\hline & & \#2 & Trace & Trace & ND & ND & ND & ND & ND & ND \\
\hline \multirow[t]{2}{*}{$\widehat{S S L-29-04}$} & ECD2 & $\# 1$ & ND & ND & ND & ND & ND & ND & ND & $\overline{N D}$ \\
\hline & & \#2 & Trace & Trace & ND & ND & ND & ND & Trace & ND \\
\hline \multirow[t]{2}{*}{ SSL-29-05 } & ECD2 & $\# 1$ & ND & ND & ND & $\overline{\mathrm{ND}}$ & ND & ND & ND & ND \\
\hline & & \#2 & Trace & ND & ND & ND & ND & ND & ND & ND \\
\hline \multirow[t]{2}{*}{ SSL-29-06 } & ECD2 & $\# 1$ & $\overline{\text { (Invalid) }}$ & $\overline{\text { (Invalid) }}$ & $\overline{\text { (Invalid) }}$ & (Invalid) & (Invalid) & $\overline{\text { (Invalid) }}$ & $\overline{\text { (Invalid) }}$ & (Invalid) \\
\hline & & \#2 & Trace & Trace & ND & ND & ND & ND & ND & ND \\
\hline \multirow[t]{2}{*}{ SSL-29-07 } & ECD2 & $\# 1$ & ND & ND & ND & ND & ND & ND & ND & ND \\
\hline & & \#2 & (Invalid) & (Invalid) & (Invalid) & (Invalid) & (Invalid) & (Invalid) & (Invalid) & (Invalid) \\
\hline \multirow[t]{2}{*}{ SSL-29-08 } & ECD2 & $\# 1$ & ND & ND & ND & ND & $\overline{N D}$ & ND & ND & $\overline{N D}$ \\
\hline & & \#2 & Trace & Trace & ND & ND & ND & ND & ND & ND \\
\hline
\end{tabular}

Table 20: Depth Discrete Soil-Plug Concentrations associated with Boring SSL-30 collected on July 12, 2000 along Tims Branch Seepline.

\begin{tabular}{|c|c|c|c|c|c|c|c|c|c|c|}
\hline Average of & f Soil (ug/g & & Analyte & & & & & & & \\
\hline Sample ID & Detector & Sample & PCE & TCE & C-DCE & T-DCE & 11DCE & CHCL3 & CCL4 & TCA \\
\hline SSL-30-01 & ECD2 & $\# 1$ & ND & ND & ND & ND & ND & ND & ND & ND \\
\hline & & \#2 & Trace & ND & ND & ND & ND & ND & ND & ND \\
\hline SSL-30-02 & ECD2 & \#1 & ND & ND & ND & ND & ND & ND & ND & ND \\
\hline & & \#2 & ND & ND & ND & ND & ND & ND & ND & ND \\
\hline SSL-30-03 & ECD2 & \#1 & ND & ND & $\overline{N D}$ & $\overline{N D}$ & ND & $\overline{N D}$ & ND & ND \\
\hline & & \#2 & ND & ND & ND & ND & ND & ND & ND & ND \\
\hline SSL-30-05 & ECD2 & $\# 1$ & ND & ND & ND & ND & ND & ND & ND & ND \\
\hline & & \#2 & Trace & ND & ND & ND & ND & ND & ND & ND \\
\hline SSL-30-06 & ECD2 & $\# 1$ & $\overline{N D}$ & ND & $\overline{N D}$ & $\overline{N D}$ & $\overline{N D}$ & $\overline{N D}$ & $\overline{N D}$ & $\overline{N D}$ \\
\hline & & \#2 & Trace & ND & ND & ND & ND & ND & ND & ND \\
\hline SSL-30-07 & ECD2 & $\# 1$ & ND & $\overline{N D}$ & $\overline{N D}$ & ND & ND & ND & ND & ND \\
\hline & & \#2 & Trace & ND & ND & ND & ND & ND & ND & ND \\
\hline SSL-30-08 & ECD2 & \#1 & ND & ND & ND & ND & ND & ND & ND & ND \\
\hline & & \#2 & Trace & Trace & ND & ND & ND & ND & ND & ND \\
\hline SSL-30-09 & ECD2 & $\# 1$ & (Invalid) & (Invalid) & (Invalid) & (Invalid) & (Invalid) & $($ Invalid) & (Invalid) & (Invalid) \\
\hline & & \#2 & (Invalid) & (Invalid) & (Invalid) & (Invalid) & (Invalid) & (Invalid) & (Invalid) & (Invalid) \\
\hline SSL-30-10 & ECD2 & \#1 & (Invalid) & (Invalid) & (Invalid) & (Invalid) & (Invalid) & (Invalid) & (Invalid) & (Invalid) \\
\hline & & \#2 & Trace & Trace & ND & ND & ND & ND & ND & ND \\
\hline SSL-30-11 & ECD2 & $\# 1$ & ND & ND & ND & $\overline{N D}$ & ND & $\overline{N D}$ & $\overline{N D}$ & ND \\
\hline & & \#2 & Trace & ND & ND & ND & ND & ND & ND & ND \\
\hline
\end{tabular}


Table 21: Depth Discrete Soil-Plug Concentrations associated with Boring SSL-31 collected on August 14, 2000 along Tims Branch Seepline.

\begin{tabular}{|c|c|c|c|c|c|c|c|c|c|c|}
\hline \multicolumn{3}{|c|}{ Average of Soil $(\mathrm{ug} / \mathrm{g})$} & \multicolumn{8}{|l|}{ Analyte } \\
\hline Sample ID & Detector & Sample & PCE & TCE & C-DCE & T-DCE & 11DCE & CHCL3 & CCL4 & TCA \\
\hline \multirow[t]{2}{*}{ SSL-31-01 } & ECD2 & \#1 & ND & ND & ND & ND & ND & ND & ND & ND \\
\hline & & \#2 & ND & ND & ND & ND & ND & ND & ND & ND \\
\hline \multirow[t]{2}{*}{ SSL-31-02 } & ECD2 & $\# 1$ & ND & ND & ND & ND & $\overline{N D}$ & ND & ND & ND \\
\hline & & \#2 & ND & ND & ND & ND & ND & ND & ND & ND \\
\hline \multirow[t]{2}{*}{ SSL-31-03 } & ECD2 & $\# 1$ & $\overline{N D}$ & ND & $\overline{N D}$ & $\overline{N D}$ & ND & ND & ND & ND \\
\hline & & \#2 & ND & ND & ND & ND & ND & ND & ND & ND \\
\hline \multirow[t]{2}{*}{ SSL-31-04 } & ECD2 & $\# 1$ & ND & ND & ND & ND & ND & ND & ND & ND \\
\hline & & \#2 & ND & ND & ND & ND & ND & ND & ND & ND \\
\hline \multirow[t]{2}{*}{ SSL-31-05 } & ECD2 & $\# 1$ & Trace & ND & $\overline{N D}$ & $\overline{N D}$ & $\overline{N D}$ & ND & ND & ND \\
\hline & & \#2 & Trace & ND & ND & ND & ND & ND & ND & ND \\
\hline
\end{tabular}

Table 22: Depth Discrete Soil-Plug Concentrations associated with Boring SSL-32 collected on August 14, 2000 along Tims Branch Seepline.

\begin{tabular}{|c|c|c|c|c|c|c|c|c|c|c|}
\hline \multicolumn{3}{|c|}{ Average of Soil (ug/g) } & Analyte & \multirow{2}{*}{ TCE } & \multirow[b]{2}{*}{ C-DCE } & \multirow[b]{2}{*}{ T-DCE } & \multirow[b]{2}{*}{ 11DCE } & \multirow[b]{2}{*}{ CHCL3 } & \multirow[b]{2}{*}{ CCL4 } & \multirow[b]{2}{*}{ TCA } \\
\hline Sample ID & Detector & Sample & $\overline{\mathrm{PCE}}$ & & & & & & & \\
\hline \multirow[t]{2}{*}{ SSL-32-01 } & ECD2 & $\# 1$ & Trace & Trace & ND & ND & ND & ND & Trace & ND \\
\hline & & \#2 & ND & ND & ND & ND & ND & ND & ND & ND \\
\hline \multirow[t]{2}{*}{ SSL-32-02 } & ECD2 & $\# 1$ & ND & ND & ND & ND & ND & ND & ND & ND \\
\hline & & \#2 & ND & ND & ND & ND & ND & ND & ND & ND \\
\hline \multirow{2}{*}{ SSL-32-03 } & ECD2 & $\# 1$ & ND & ND & ND & ND & ND & ND & ND & ND \\
\hline & & \#2 & Trace & ND & ND & ND & ND & ND & ND & ND \\
\hline \multirow[t]{2}{*}{ SSL-32-04 } & ECD2 & $\# 1$ & Trace & ND & ND & ND & ND & ND & ND & ND \\
\hline & & \#2 & Trace & ND & ND & ND & ND & ND & ND & ND \\
\hline \multirow[t]{2}{*}{ SSL-32-05 } & ECD2 & \#1 & ND & ND & ND & ND & ND & ND & ND & ND \\
\hline & & \#2 & ND & ND & ND & ND & ND & ND & ND & ND \\
\hline
\end{tabular}



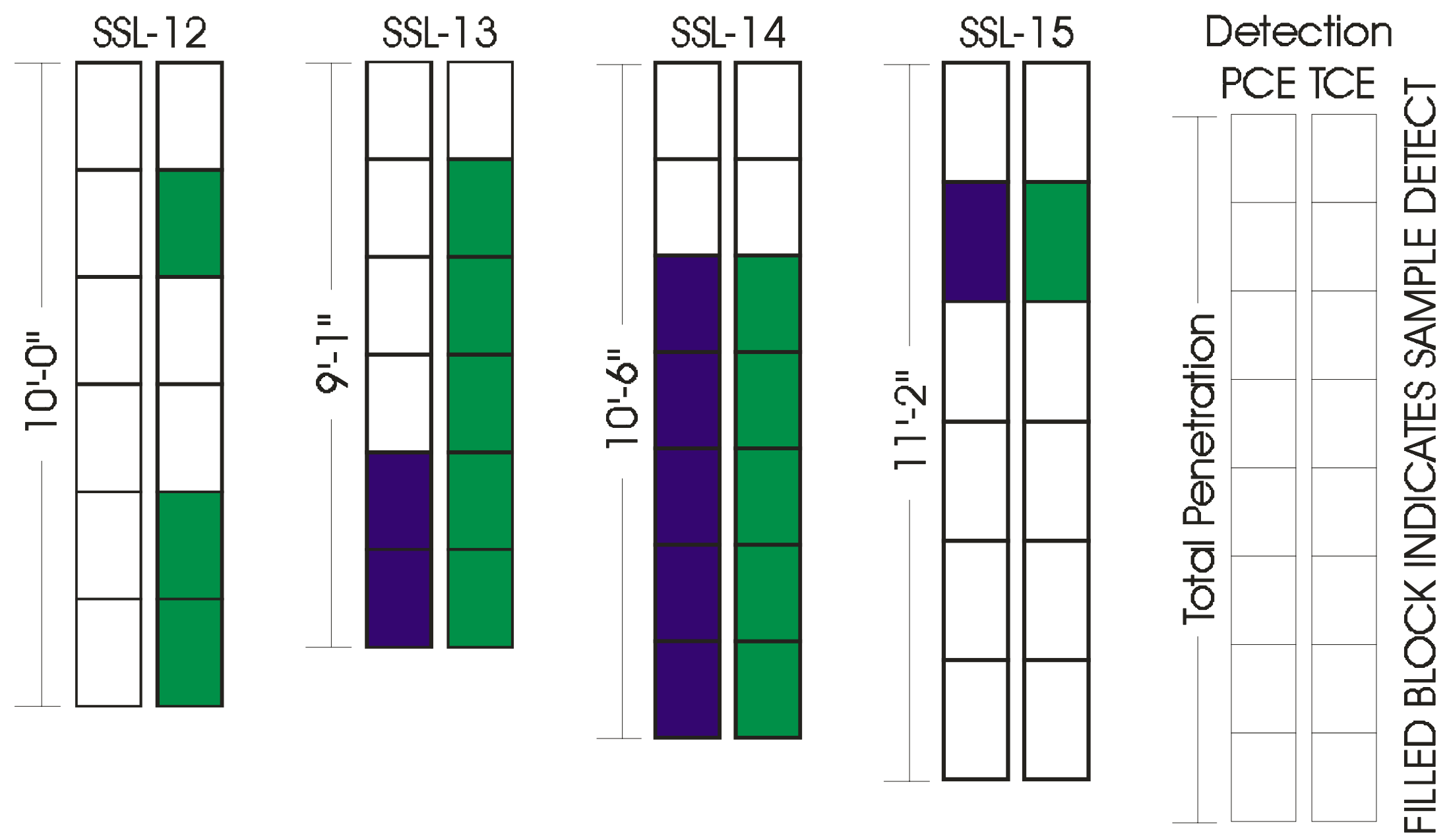

Figure 6: Depth-Discrete Interpretation of Analytical Results from Borings SSL-12, SSL-13, SSL-14, and SSL-15 indicating the Presence of Trace Quantities of Trichloroethylene and Tetrachloroethylene. 

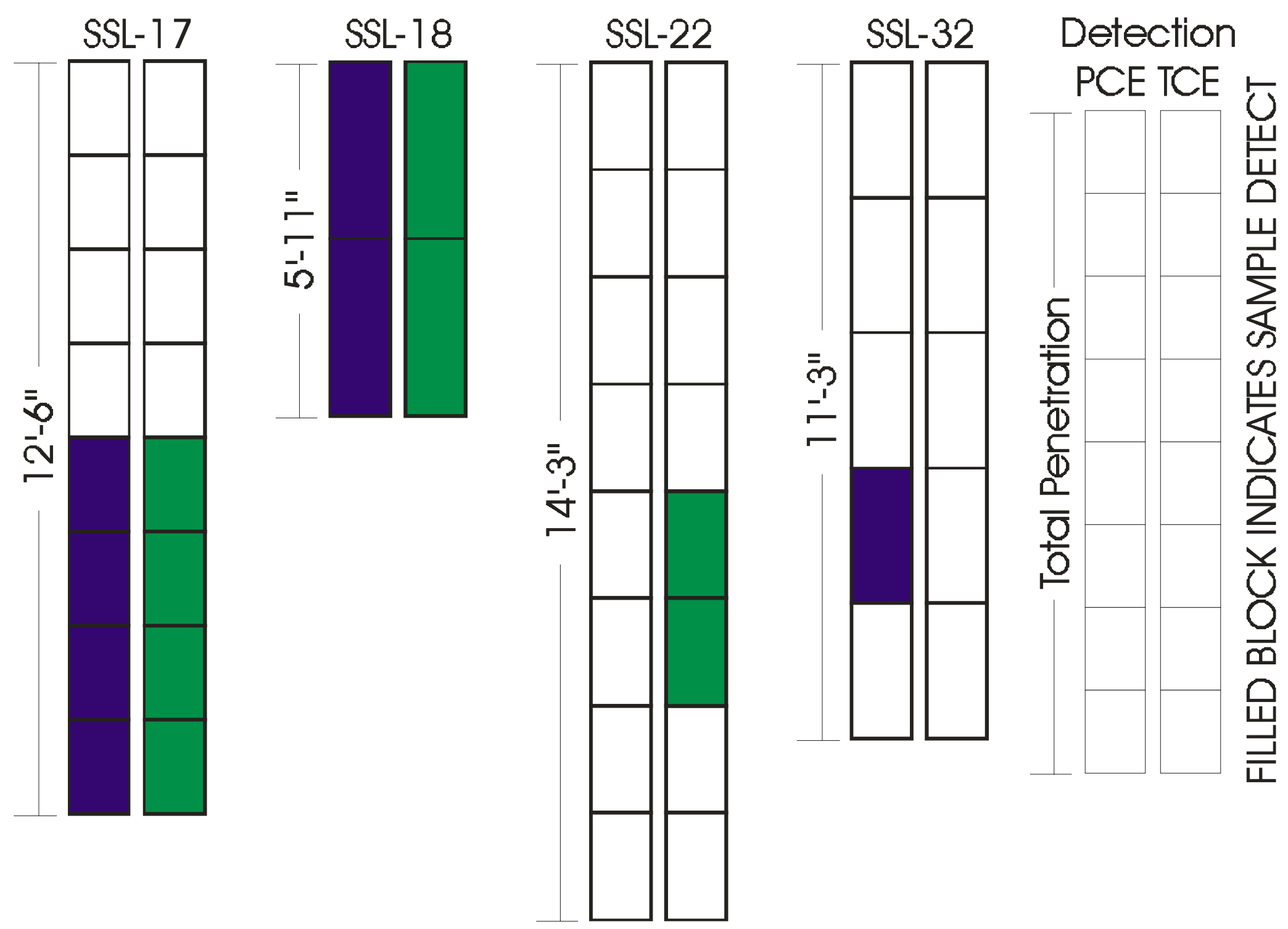

Figure 7: Depth-Discrete Interpretation of Analytical Results from Borings SSL-17, SSL-18, SSL-22, and SSL-32 indicating the Presence of Trace Quantities of Trichloroethylene and Tetrachloroethylene. 


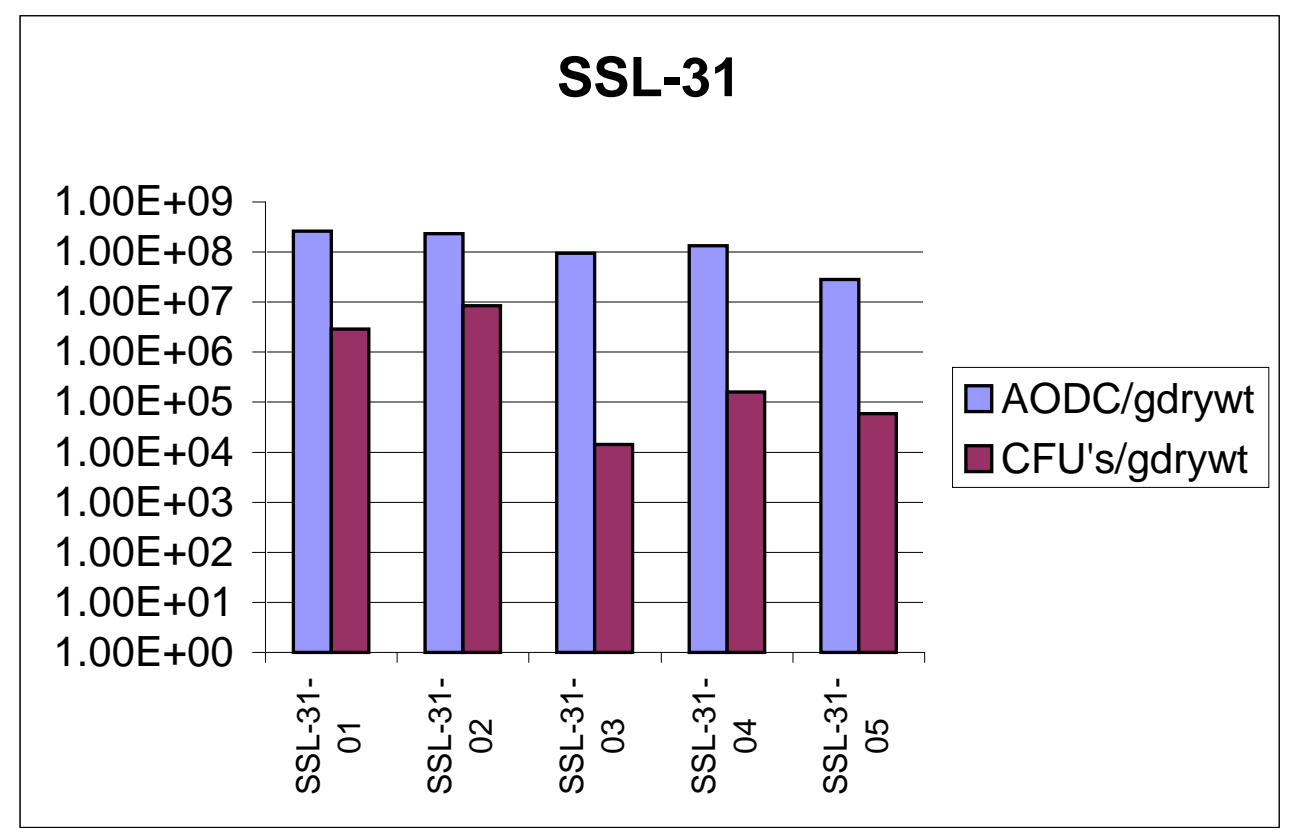

Figure 8: Total Microbial densities (AODC) and Colony Forming Units (CFU) for SSL-31 sediment samples collected on August 14, 2000.

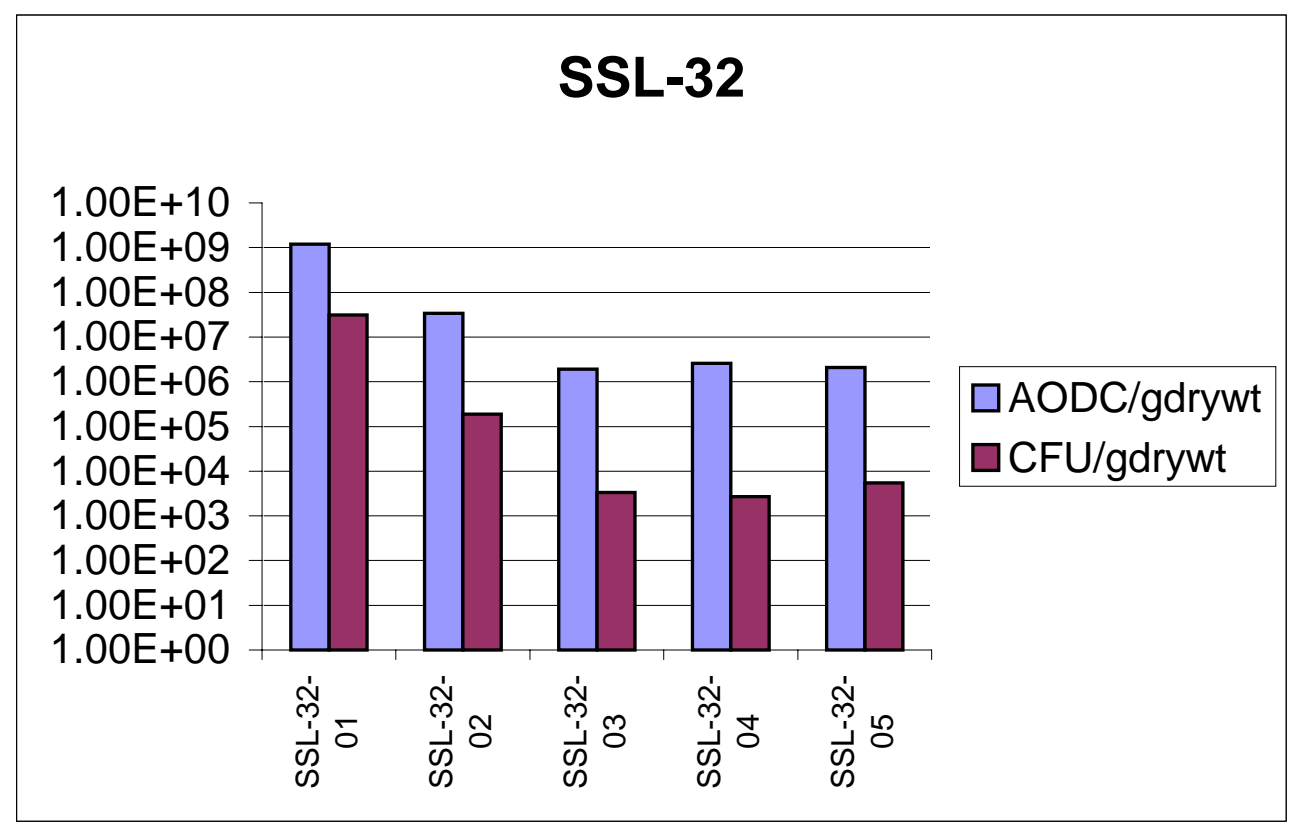

Figure 9: Total Microbial densities (AODC) and Colony Forming Units (CFU) for SSL-32 sediment samples collected on August 14, 2000. 
Table 23: Summary of PLFA Results for Southern Sector Seepline Sediment Samples from SSL-31 and SSL-32.

\begin{tabular}{|c|c|c|c|c|c|c|c|c|c|c|c|c|c|}
\hline \multirow[b]{2}{*}{ Sample } & \multicolumn{5}{|c|}{ Biomass (pmoles PLFA/g wt.) } & \multicolumn{6}{|c|}{ Community Structure (\% of total) } & \multicolumn{2}{|c|}{$\begin{array}{l}\text { Physiological } \\
\text { status }\end{array}$} \\
\hline & $\begin{array}{c}\text { Total } \\
\text { Biomass }\end{array}$ & $\begin{array}{l}\text { Cell equivalent } \\
\text { value/g wt (1) }\end{array}$ & $\begin{array}{l}\text { Bacterial } \\
\text { biomass }\end{array}$ & $\begin{array}{c}\text { Eukaryotic } \\
\text { biomass }\end{array}$ & $\begin{array}{c}\text { ratio } \\
\text { bacterial } \\
\text { eukaryote }\end{array}$ & $\begin{array}{c}\text { Gram+l } \\
\text { anaerobic } \\
\text { Gram - } \\
\text { (TerBrSats) }\end{array}$ & $\begin{array}{l}\text { Gram - } \\
\text { (Monos) }\end{array}$ & $\begin{array}{c}\text { Anaerobic } \\
\text { metal } \\
\text { reducers } \\
\text { (BrMonos) }\end{array}$ & $\begin{array}{c}\text { SRB/ } \\
\text { Actinomycetes } \\
\text { (MidBrSats) }\end{array}$ & $\begin{array}{l}\text { Genera } \\
\text { (Nsats) }\end{array}$ & $\begin{array}{l}\text { Eukaryotes } \\
\text { (polyenoics) }\end{array}$ & $\begin{array}{c}\text { Growth } \\
\text { Phase } \\
\text { (ratio } \\
\text { cy/w7c) }\end{array}$ & $\begin{array}{c}\text { Adaptation } \\
\text { (w7t/w7c) }\end{array}$ \\
\hline$\overline{\text { SSL-31-01 }}$ & 25,737 & $5.15 \mathrm{E}+08$ & 22,494 & 3,243 & 7 & 15.1 & 41.9 & 2.8 & 9.5 & 18.1 & 12.6 & 3.81 & 0.14 \\
\hline$\overline{S S L-32-01}$ & 39,624 & $7.92 E+08$ & 31,552 & 8,071 & 4 & 12.0 & 36.8 & 3.0 & 6.6 & 21.2 & 20.4 & 2.50 & 0.00 \\
\hline$\overline{\text { SSL-32-05 }}$ & 14 & $2.76 \mathrm{E}+05$ & 8 & 5 & 2 & 2.0 & 30.5 & 0.0 & 7.9 & 20.8 & 38.8 & 2.00 & 0.00 \\
\hline
\end{tabular}

(1) The cell equivalent value is calculated from experiments with typical bacteria isolated from soil and water. This value is based on $2.0 \times 10^{12}$ cells per gram dry weight of cells and $10^{8}$ picomoles of phospholipid/gram dry weight of cells. The number of cells/gram of dry weight may vary and is dependent on the environmental conditions from which the microorganisms were recovered. 
(This Page Intentionally Blank) 


\section{Stage III: Monitoring Well Installation}

In order to provide quantitative information on the magnitude of the volatile organic compounds that that were detected near the outcrop zone of Tims Branch, fixed monitoring points were established along the seepline. In Stage III of this investigation five (5) fixed monitoring points were installed along this seepline based on results from the diffusion sampling and vibracore characterization activities. The wells were installed as Vibrawells; a vibracore assisted technique for the installation of monitoring wells in remote and/or ecologically sensitive areas. The installation involved the sinking of a 4-inch well casing using a vibracoring machine followed by hand augering and installation of a 2-inch monitoring well with filter pack. The filter pack, appropriate bentonite seals, and grout columns were added as the 4-inch casing was removed from the subsurface. Installation of Vibrawells results in minimal damage to the environment when compared to traditional drilling technologies as the equipment and materials are relatively portable. The ability to incorporate a filter pack and appropriate bentonite seals between the individual monitoring zones is considered an important aspect of the installation approach. These aspects add significant value over alternative shallow well-installation techniques such as hand augering or direct drive points.

Initial plans were for each monitoring location to contain two (2) independent screen zones based on the StrataSampler devices. In this configuration a 2-foot StrataSampler was planned for installation in conjunction with a standard five-foot screen section. The StrataSampler would target the deeper zone and would be used to monitor the contaminant plume. The standard screen would be used to target the shallow water-table interface and would be used to monitor this elevation and conditions. This approach would allow monitoring of groundwater in what is considered to be the upper portion of the contaminated plume and that portion of the subsurface where root systems have the most active groundwater withdrawals.

The StrataSampler is a device that can be used for the collection of either soil vapor or water samples depending on where in the subsurface that the device is deployed. Multiple StrataSampler devices can be placed in a single borehole to allow the collection of discrete samples from several different depths. The StrataSampler is comprised of a slotted sample chamber, 2-inches in diameter with an inner pass-through to allow use of tubing for connection of deeper StrataSampler devices with the surface for sample collection. The sample intervals in the StrataSampler system are all isolated from each other and do not require secondary isolation using packers, reducing the potential for vertical migration within the monitoring well. The device has a simple, yet functional design that requires no special installation method.

The five monitoring wells located along the seepline were installed in a one (1) week period between August 14 and August 17, 2000. The monitoring wells were then developed over the next two (2) weeks. Monitoring wells installed with the StrataSampler devices were developed using a paristaltic pump operating at a flow of approximately 3.4 liters per minute. Development continued until turbidity was reduced and water quality parameters including $\mathrm{pH}$, dissolved oxygen, and specific conductance stabilized. Those wells with traditional wire-wrap screens, SSL-20C and SSL-30C, were developed in a similar manner using a 12 volt submersible pump mini-pump (Model XP-100) operating at approximately 5 gallons per minute. As indicated in the well installation report, monitoring well SSL-13C pumped dry after 15-20 minutes of pumping and was not adequately developed. Final, as-built surveying was completed on October 26, 2000. A summary of the construction information for the five seepline monitoring wells installed along 
Tims Branch is presented in Table 24. Detailed information on monitoring well construction and development are included in the Appendix. Monitoring wells installed at locations SSL-13, SSL17, and SSL-25 were multi-level wells incorporating the StrataSampler device as previously described. Monitoring wells installed at locations SSL-20 and SSL-30 were installed in a conventional fashion with a single saturated five-foot screen zone. The multi-level configuration was not used at these locations due to the presence of a fine-grained silt/clay at what would represent the shallow water table zone.

Following development the monitoring wells were sampled and analyzed for VOCs. Following collection, each sample was transported to the laboratory and analyzed using a modified headspace analysis technique based on EPA Method 5021. Sample analysis was performed at SRTC laboratories using a Hewlett Packard 5890 Series II gas chromatograph with electron capture (ECD) and flame ionization detectors (FID) in parallel with an automated head space sampler at $70^{\circ} \mathrm{C}$ to determine equivalent water concentrations. The gas chromatograph was calibrated using either stock methanol solutions made with neat (pure) solvents or purchased certified mixtures in methanol that were diluted in de-ionized water to the specific concentrations. The standard concentrations used for the headspace calibration were $3 \mu \mathrm{g} / \mathrm{l}, 5$ $\mu \mathrm{g} / \mathrm{l}, 10 \mu \mathrm{g} / \mathrm{l}, 50 \mu \mathrm{g} / \mathrm{l}, 100 \mu \mathrm{g} / \mathrm{l}, 1 \mathrm{mg} / \mathrm{l}$, and $10 \mathrm{mg} / \mathrm{l}$. The samples were analyzed for Freon-11, Freon-113, 1,1-dichloroethylene, trans-dichloroethylene, cis-dichloroethylene, trichloromethane, 1,1,1-trichloroethane, tetrachloromethane, trichloroethylene and tetrachloroethylene.

The analytical results from the initial sampling activities associated with the seepline monitoring wells that were installed are presented in Table 25. This data indicates that the groundwater concentrations near the seepline are approximately $50 \mu \mathrm{g} / \mathrm{l}$ for trichloroethylene at the northern end of the study area. As with the results from the diffusion samplers and the coring activities previously presented, detectable concentrations were indicated in a 1700-foot region between monitoring wells SSL-13 and SSL-17. Sampling results associated with monitoring well SSL-20 did not indicate the presence of detectable levels of trichloroethylene or tetrachloroethylene. As indicated by the results presented in Table 25, no significant levels of anaerobic degradation products were observed in the monitoring well samples. In Figure 10, those monitoring wells where the volatile organic compounds trichloroethylene and tetrachloroethylene were detected are presented with filled symbols. 
Table 24: Summary of Construction Information for Seepline Monitoring Wells Installed Along Tims Branch.

\begin{tabular}{|c|c|c|c|c|c|c|}
\hline \multirow{2}{*}{ Well ID } & \multicolumn{2}{|c|}{ SRS Coordinates } & \multirow{2}{*}{$\begin{array}{c}\text { Casing } \\
\text { Elevation }\end{array}$} & \multirow[t]{2}{*}{ Screen Description } & \multicolumn{2}{|c|}{ Screen Depths } \\
\hline & Northing & Easting & & & Top & Bottom \\
\hline SSL-13B & $93555.10 \mathrm{ft}$ & $51072.97 \mathrm{ft}$ & 195.48 feet & $\begin{array}{l}2 \text { Foot 2" Stainless Steel } \\
\text { StrataSampler with a 10-Slot Wire } \\
\text { Wrap Screen Zone. }\end{array}$ & 16.5 feet & 18.5 feet \\
\hline SSL-13C & $93555.10 \mathrm{ft}$ & $51072.97 \mathrm{ft}$ & 195.481 feet & $\begin{array}{l}5 \text { Foot } 2 \text { " PVC Pipe with a Slotted } \\
\text { 10-Slot Screen Zone. }\end{array}$ & 1.5 feet & 6.5 feet \\
\hline SSL-17B & $91879.76 \mathrm{ft}$ & $50751.76 \mathrm{ft}$ & 186.84 feet & $\begin{array}{l}2 \text { Foot 2" Stainless Steel } \\
\text { StrataSampler with a 10-Slot Wire } \\
\text { Wrap Screen Zone. }\end{array}$ & 13 feet & 15 feet \\
\hline SSL-17C & $91879.76 \mathrm{ft}$ & $50751.76 \mathrm{ft}$ & 186.84 feet & $\begin{array}{l}5 \text { Foot } 2 \text { " PVC Pipe with a Slotted } \\
\text { 10-Slot Screen Zone. }\end{array}$ & 2.5 feet & 7.5 feet \\
\hline SSL-20C & $89944.37 \mathrm{ft}$ & $48671.31 \mathrm{ft}$ & 179.48 feet & $\begin{array}{l}5 \text { Foot } 2 \text { " PVC Pipe with a Slotted } \\
\text { 10-Slot Screen Zone. }\end{array}$ & 13.8 feet & 18.8 feet \\
\hline SSL-25B & $84524.11 \mathrm{ft}$ & $49057.52 \mathrm{ft}$ & 148.30 feet & $\begin{array}{l}2 \text { Foot 2" Stainless Steel } \\
\text { StrataSampler with a 10-Slot Wire } \\
\text { Wrap Screen Zone. }\end{array}$ & 13.5 feet & 15.5 feet \\
\hline SSL-25C & $84524.11 \mathrm{ft}$ & $49057.52 \mathrm{ft}$ & 148.30 feet & $\begin{array}{l}5 \text { Foot } 2 \text { " PVC Pipe with a Slotted } \\
\text { 10-Slot Screen Zone. }\end{array}$ & 3.25 feet & 8.25 feet \\
\hline SSL-30C & $89114.94 \mathrm{ft}$ & $48791.04 \mathrm{ft}$ & 170.50 feet & $\begin{array}{l}5 \text { Foot 2" PVC Pipe with a Slotted } \\
\text { 10-Slot Screen Zone. }\end{array}$ & 9.5 feet & 14.5 feet \\
\hline
\end{tabular}


Table 25: Analytical Results from Initial Sampling Activities Associated with Seepline Monitoring Wells.

\begin{tabular}{|c|c|c|c|c|c|c|c|c|c|}
\hline Well ID & $\begin{array}{c}\text { Sample } \\
\text { Date }\end{array}$ & 11DCE & T-DCE & C-DCE & CHCL3 & TCA & CCL4 & TCE & PCE \\
\hline SSL-13B & $08 / 21 / 00$ & - & - & - & - & - & - & 47.14 & 18.09 \\
\hline SSL-13B & $08 / 21 / 00$ & - & - & - & - & - & - & 70.53 & 26.76 \\
\hline SSL-13B & $08 / 28 / 00$ & - & - & - & - & - & - & 49.59 & 20.41 \\
\hline SSL-13B & $08 / 28 / 00$ & - & - & - & - & - & - & 45.88 & 18.13 \\
\hline SSL-17B & $08 / 22 / 00$ & - & - & - & - & - & - & Trace & Trace \\
\hline SSL-17B & $08 / 22 / 00$ & - & - & - & - & - & - & Trace & Trace \\
\hline SSL-17B & $08 / 28 / 00$ & - & - & - & - & - & - & Trace & Trace \\
\hline SSL-17B & $08 / 28 / 00$ & - & - & - & - & - & - & Trace & Trace \\
\hline SSL-17C & $08 / 22 / 00$ & - & - & - & - & - & - & Trace & Trace \\
\hline SSL-17C & $08 / 22 / 00$ & - & - & - & - & - & - & Trace & Trace \\
\hline SSL-17C & $08 / 28 / 00$ & - & - & - & - & - & - & Trace & Trace \\
\hline SSL-17C & $08 / 28 / 00$ & - & - & - & - & - & - & Trace & Trace \\
\hline SSL-20C & $08 / 21 / 00$ & - & - & - & - & - & - & - & - \\
\hline SSL-20C & $08 / 21 / 00$ & - & - & - & - & - & - & - & - \\
\hline SSL-20C & $08 / 28 / 00$ & - & - & - & - & - & - & - & - \\
\hline SSL-20C & $08 / 28 / 00$ & - & - & - & - & - & - & - & - \\
\hline SSL-25B & $08 / 28 / 00$ & - & - & - & - & - & - & - & - \\
\hline SSL-25B & $08 / 28 / 00$ & - & - & - & - & - & - & - & - \\
\hline SSL-25C & $08 / 28 / 00$ & - & - & - & - & - & - & - & - \\
\hline SSL-25C & $08 / 28 / 00$ & - & - & - & - & - & - & - & - \\
\hline SSL-30C & $08 / 21 / 00$ & - & - & - & - & - & - & - & - \\
\hline SSL-30C & $08 / 22 / 00$ & - & - & - & - & - & - & - & - \\
\hline SSL-30C & $08 / 28 / 00$ & - & - & - & - & - & - & - & - \\
\hline SSL-30C & $08 / 28 / 00$ & - & - & - & - & - & - & - & - \\
\hline
\end{tabular}

(All Results presented in units of $\mu \mathrm{g} / \mathrm{l}$.) 
Lost Lake Outcrop Zone

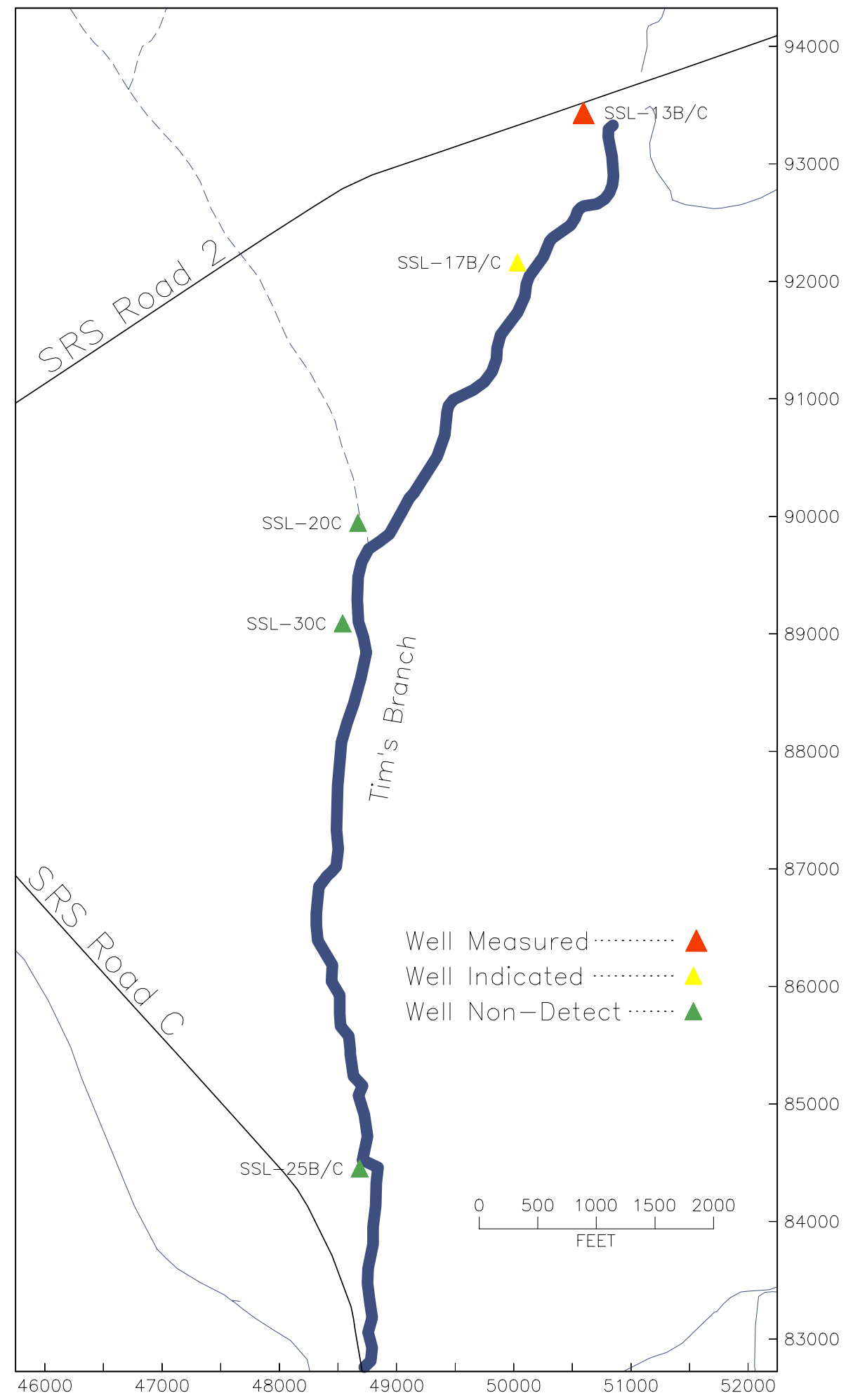

Figure 10: Location of Monitoring Wells that were Installed along the Seepline Between SRS Road 2 and SRS Road C. 
(This Page Intentionally Blank) 


\section{Interpretation and Discussion:}

The objective of this investigation was to provide detailed information on the lateral extent of volatile organic contaminants outcropping along Tims Branch. In determining this a weight of evidence approach was applied to compare results from the numerous characterization activities associated with this and previous investigations. This approach is especially important when examining concentrations on the level of those observed throughout this investigation. The extent of the study area was presented in Figure 1 and extends along Tims Branch from SRS Road 2 to SRS Road C. Within this area the elevation of the stream decreases more than 50 feet and has a length of approximately 2.34 miles.

Diffusion based sampling techniques suggest detectable concentrations of trichloroethylene and tetrachloroethylene in the hyporheic zone near the SRS Road 2. The sampling indicates that trichloroethylene and tetrachloroethylene are present a distance of approximately 2200 feet south of Road 2. Because of mixing between groundwater and surface water in the hyporheic zone, the chemical and biological character of this zone may be significantly different from adjacent surface water and groundwater (Winter et al. 1998). Coring activities using vibracore techniques, accompanied with depth-discrete sediment analysis corroborates the results of the diffusion based sampling and suggests that the plume is located in an approximately 1700-foot region between borings SSL-13 and SSL-17 south of SRS Road 2. Although the results are not quantifiable due to the low concentrations, the number and distribution of samples support the conceptual model of groundwater flow and contaminant transport previously presented for the plume in the Southern Sector.

The vibracoring results also indicated that the plume might be present in a region near boring SSL-12, south of an area of increased surface impoundment associated with beaver habitat. This was the region previously identified in the initial phytoremediation characterization activities (Jerome et al. 1999). Monitoring wells installed at boring SSL-13 and SSL-17 confirmed the presence of trichloroethylene and tetrachloroethylene contamination near the northern extent of the study area. Sampling results associated with monitoring well SSL-20 in the vicinity of the surface impoundment did not indicate the presence of trichloroethylene or tetrachloroethylene at this loaction. These results are summarized in Figure 11. This is consistent with the conceptual extension of the trichloroethylene plume that was based on previous seepline characterization activities and presented in Figure 1. (Jerome et al. 1999).

Using nominal concentration values along the extent of the seepline, along with the magnitude of groundwater flux previously determined from USGS gage records, the plume mass flux was estimated. Estimates of the average baseflow using hydrograph separation techniques indicate the average groundwater flow in the vicinity of the suspected outcrop region is 2.65 cubic feet of groundwater per second. As indicated by regional water table maps, in this vicinity Tims Branch is considered to represent a discharge zone of the shallow Lost Lake aquifer (Hiergesell 1998). As a result, half of the baseflow is considered to be associated with groundwater from the A/MArea, including the plume associated with the Southern Sector, and the other half is associated with groundwater on the eastern side of the stream. The nominal concentration associated with the wells in the outcrop region is $25 \mu \mathrm{g} / \mathrm{l}$ for trichloroethylene and $10 \mu \mathrm{g} / \mathrm{l}$ for tetrachloroethylene and the width of region is considered to be 2000 feet. With these values the estimated mass flux to the hyporheic zone would be approximately 64 pounds $(29 \mathrm{~kg})$ per year for trichloroethylene and approximately 26 pounds $(12 \mathrm{~kg})$ per year for tetrachloroethylene. A summary of these 
calculations is presented in the Appendix of this report. Continued monitoring of concentrations, stream flow, and surface water quality are necessary to confirm the initial observations and to address the uncertainties identified below.

The PLFA profiles associated with the microbial analysis revealed that the samples, with the exception of SSL-32-05, contained a relatively diverse microbial community. This community is primarily composed of Gram-negative bacteria (indicated by percentage of monoenoic PLFA) which is a positive bioremediation indicator. In particular the ratio of sulfate reducing bacteria (SRB) to total community structure is a good indication of anaerobic dechlorination potential in SSL-31-05.

The presence of the beaver habitat within the study area are considered to effect the interactions of groundwater and surface water in a manner similar to that associated with a lake or ponds. In these systems the interactions are influenced by the surrounding landscape and the fraction of surface water, precipitation, and groundwater that is received (Freeze and Cherry 1979; Winter et al. 1998). The impoundment of the surface water within the study area has created a wetland region that is considered to receive discharges of groundwater from the Lost Lake aquifer, from surrounding surface runoff, and from stream baseflow. Interactions of groundwater and lakes are different from streams in that most lakes are considered to receive groundwater inflow through part of the bed and have seepage loss through other parts (Fetter 1994; Winter et al. 1998).

From a hydrologic perspective three additional subtleties exist with the interaction of groundwater and surface wetlands and could effect the mass flux in the hyporheic zone. The first is that in wetlands containing fine-grained and highly decomposed organic sediments, the rate of water and dissolved solutes between the groundwater and the surface water is likely to be much slower. The distribution of the fine-grained and organic sediments can affect the distribution of seepage and biogeochemical exchanges of water and solutes in wetlands compared to that in streams. The second is that in wetland environments the fibrous root mat in the wetland soils is conductive to water flow; therefore, water uptake by roots of emergent plants results in significant interchange between surface water and pore water of wetland sediments. This water exchange in the upper soil zone occurs even if the exchange between the surface water and groundwater is restricted at the base of the wetland sediments (Winter et al. 1998). The effects on hydraulic head and associated variations in plume location and migration related to these issues are uncertain and should be further investigated. Finally, the depth discrete data indicates that the plume only occupies a portion of the discharge aquifer zone. This factor must be considered, based on future studies, before more accurate fluxes can be made.

Based on the distribution and magnitude of concentrations observed in this and previous investigations, the leading edge of the volatile organic plume associated with $\mathrm{A} / \mathrm{M}$ Area is considering to be cropping out in the hyporheic zone along Tims Branch near the intersection of SRS Road 2. The width of the outcrop region is considered to be on the order of 2000 feet. The concentrations associated with this region range up to approximately $50 \mu \mathrm{g} / \mathrm{l}$ for trichloroethylene and $20 \mu \mathrm{g} / \mathrm{l}$ for tetrachloroethylene. Upon entering the stream these concentrations would be diluted by more than $50 \%$ with the groundwater associated with the opposite side of the stream, by upstream component of flow, and by local components of overland flow. A significant portion of the plume would be volatilized through air-to-water partitioning. Due to topographic constraints and local geologic conditions the location where the plume outcrops is considered to be associated with those portions of Tims Branch below an elevation of 200 feet mean sea level. Based on the low concentrations observed relative to the 
plume in the Southern Sector the outcrop is considered to be associated with the leading edge of the contaminant plume associated with the A/M Area.

\section{Conclusions:}

Using a weight of evidence approach, the data from this study indicates that the leading edge of the volatile organic plume associated with A/M Area is considering to be located in region approximately 2000 feet wide near Tims Branch at the intersection of SRS Road 2. The findings of this study are consistent with the conceptual model for the organic contaminant plume associated with the Southern Sector of the A/M Area. The plume in the Southern Sector is known to be discrete and located primarily in the lower portion of the Lost Lake aquifer zone. A similar depth related concentration profile was observed in sediment cores collected within the northern portion of the current study area. Microbial populations are observed to be diverse in this area supporting the potential for bioremediation activities along the seepline.

In this study the geological features of coastal plain outcrops were used with fundamentals of groundwater flow and contaminant transport to direct characterization to support characterization activities to support future remediation activities and to evaluate the potential for phytoremediation or other natural sustainable treatment alternatives. By integrating the important aspects of geology and groundwater flow the flux of contaminants entering the seepline was determined. These results emphasize the importance in understanding the role of plume geometry (vertical structure and flow trajectory) in the planning of natural attenuation based clean-up strategies. These baseline measurements and characterization approaches will be of significant benefit in selecting additional characterization and remediation needs and for assessing the long-term performance of active remediation in the Central and Southern Sectors of the A/M Area. 

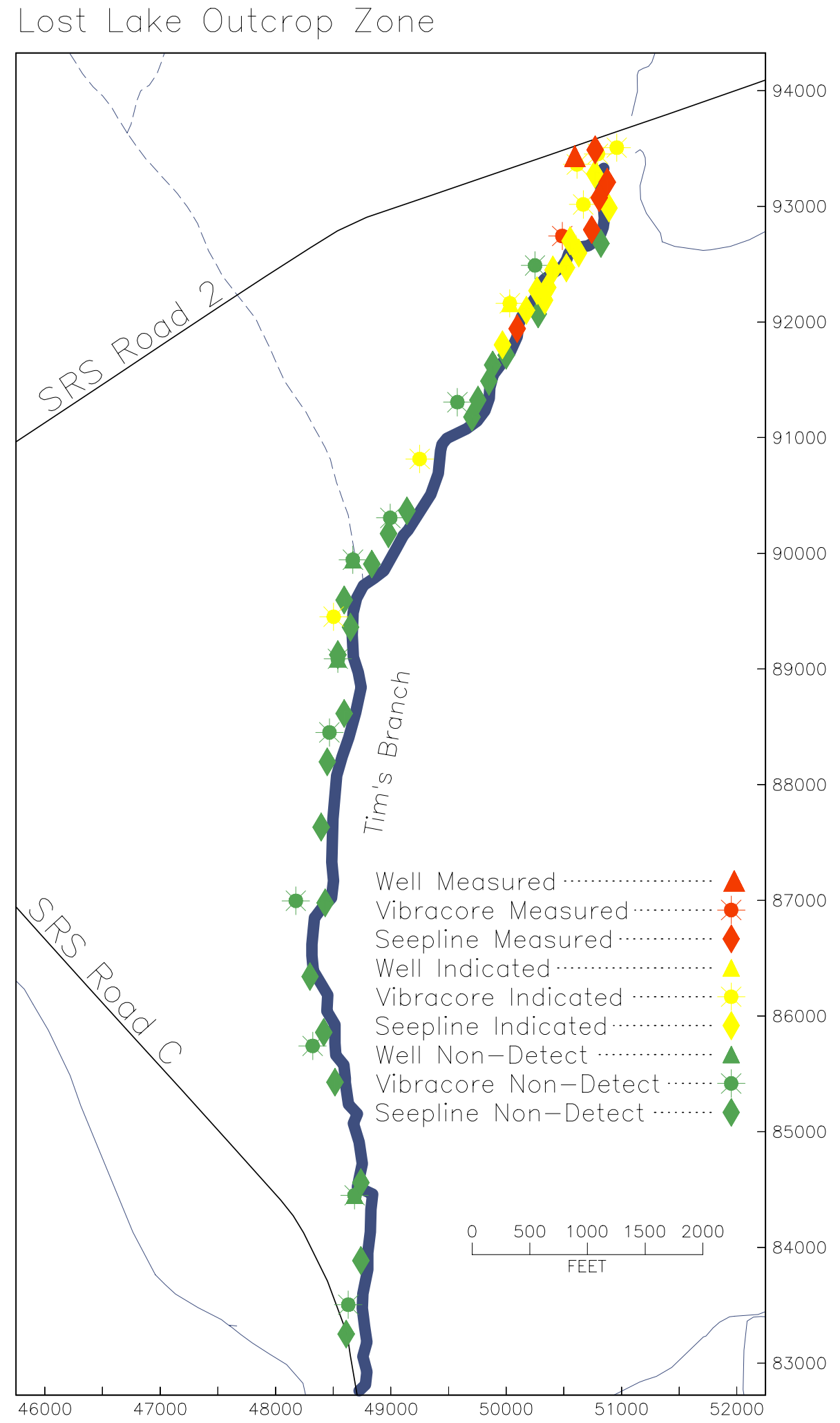

Figure 11: Summary of Diffusion, Vibracore, and Monitoring Well Sampling Results along Tims Branch Seepline Between SRS Road 2 and SRS Road C 


\section{References:}

Aadland, R. K., J. A. Gellici and P. A. Thayer (1995). Hydrogeologic Framework of WestCentral South CarolinaReport 5. Water Resources Division, South Carolina Department of Natural Resources, Columbia, South Carolina.

Aadland, R. K., S. E. Lewis and T. D. McAdams (1995). Hydrogeological Characterization Report for the A/M Area (U). Technical Report WSRC-RP-95-0052. Westinghouse Savannah River Company, Aiken, South Carolina 29808.

Aleman, S. E. and L. L. Hamm (1999). Capture Zone Analyses of Two Airlift Recirculation Wells in the Southern Sector of A/M Area (U). Technical Report WSRC-TR-99-00203. Westinghouse Savannah River Company, Aiken, South Carolina 29808.

Balkwill, D. L. (1989). "Numbers, diversity, and morphological characteristics of aerobic chemoheterotrophic bacteria in deep subsurface sediments from a site in South Carolina." Geomicrobiology Journal 7: 33-52.

Brigmon, R. L., T. A. Anderson and C. B. Fliermans (1999). "Methanotrophic Bacteria in the Rhizosphere of Trichloroethylene Degrading Plants." International Journal of Phytoremediation 1: 241-253.

Brigmon, R. L., N. C. Bell, D. L. Freedman and C. J. Berry (1998). "Natural Attenuation of Trichloroethylene in Rhizosphere Soils at the Savannah River Site." Journal of Contaminanted Soils 7: 433-453.

Cooney, T. (2000). Personal Communication regarding gage stations located along Tims Branch.

Eddy, C. A., B. B. Looney, J. M. Dougherty, T. C. Hazen and D. S. Kaback (1991). Characterization of the Geology, Geochemistry, Hydrology and Microbiology of the InSitu Air Stripping Demonstration Site at the Savannah River Site (U). Technical Report WSRC-RD-91-0021. Westinghouse Savannah River Company, Aiken, South Carolina 29808.

Fetter, C. W. (1994). Applied Hydrogeology. Upper Saddle River, New Jersey 07458, PrenticeHall Inc.

Freeze, R. A. and J. A. Cherry (1979). Groundwater. Englewood Cliffs, N.J., Prentice-Hall.

Hiergesell, R. A. (1998). The regional water table of the Savannah River Site and related coverages. Technical Report WSRC-TR-98-00045. Westinghouse Savannah River Company, Aiken, South Carolina 29808.

Jackson, D. G. and S. E. Aleman (1995). Three Dimensional Zone of Capture Analyis for the A/M Area (U). Technical Report WSRC-RP-95-0843. Westinghouse Savannah River Company, Aiken, South Carolina 29808.

Jackson, D. G., W. K. Hyde, J. Rossabi and B. D. Riha (1999). Characterization Activities to Determine the Extent of DNAPL in the Vadose Zone at the A-014 Outfall of A/M Area (U). Technical Report WSRC-RP-99-00569.

Jackson, D. G. and B. B. Looney (1996). Development of a Vertical Recirculation Well System for the A/M Area of the Savannah River Site (U). Technical Report WSRC-RP-96-0477. Westinghouse Savannah River Company, Aiken, South Carolina 29808. 
Jackson, D. G., B. B. Looney and H. W. Campbell (1997). Assessment of Chlorinated Solvent Contamination in the Crouch Branch Aquifer of the A/M Area (U). Technical Report WSRC-RP-97-0247. Westinghouse Savannah River Company, Aiken, South Carolina 29808.

Jackson, D. G., T. Payne, B. B. Looney and J. Rossabi (1996). Estimating the Extent and Thickness of DNAPL within the A/M Area of the Savannah River Site (U). Technical Report WSRC-RP-96-0574. Westinghouse Savannah River Company, Aiken, South Carolina 29808.

Jerome, K. M., J. V. Noonkester, B. B. Looney, J. L. Simmons and S. L. Baxley (1998). A/M Area DNAPL Characterization Report For Cores Collected in FY97 and 1Q98 and 2Q98 (U). Technical Report WSRC-TR-98-00296. Westinghouse Savannah River Company, Aiken, South Carolina 29808.

Jerome, K. M., J. L. Simmons and D. G. Jackson (1999). Characterization Report to Support the Phytoremediation Efforts for Southern Sector, Savannah River Site, Aiken, South Carolina (U). Technical Report WSRC-TR-99-00113. Westinghouse Savannah River Company, Aiken, South Carolina 29808.

Looney, B. B. (2000). Applied Environmental Technology Development at the Savannah River Site: A Retrospective on the Last Half of the 20th Century. Technical Manuscript WSRCMS-2000-00061. Westinghouse Savannah River Company, Aiken, South Carolina 29808.

Looney, B. B. and M. A. Phifer (1994). A/M Area Groundwater Corrective Action Southern Sector Remediation Technology Alternatives Evaluation (U). Technical Report WSRCRP-94-00607. Westinghouse Savannah River Company, Aiken, South Carolina 29808.

Looney, B. B., J. Rossabi and D. M. Tuck (1992). Assessing DNAPL Contamination, A/M-Area, Savannah River Site: Phase I Results (U). Technical Report WSRC-RP-92-1302. Westinghouse Savannah River Company, Aiken, South Carolina 29808.

Marine, I. W. and H. Bledose (1984). Supplemental Technical Summary M-Area Groundwater InvestigationDPSTD-84-0112. Savannah River Laboratory, E. I. duPont de Nemours \& Company, Aiken, South Carolina 29808.

Savoie, J. G., D. R. LeBlanc, D. S. Blackwood, T. D. McCobb, R. R. Rendigs and S. Clifford (2000). Delineation of discharge areas of two contaminant plumes by use of diffusion samplers, Johns Pond, Cape Cod, Massachusetts, 1998. Water-Resources Investigations Report 00-4017. U.S. Geological Survey, Northborough, Massachusetts.

Savoie, J. G., F. P. Lyford and S. Clifford (1998). Potential for advection of volatile organic compounds in ground water to the Cochato River, Baird \& McGuire Superfund Site, Holbrook, Massachusetts, March and April 1998. Water-Resources Investigations Report 98-4257. U.S. Geological Survey, Northborough, Massachusetts.

Sloto, R. A. and M. Y. Crouse (1996). HYSEP: A Computer Program for Streamflow Hydrograph Separation and Analysis. Water-Resources Investigations Report 96-4040. U.S. Geological Survey, Denver, Colorado 80225-0286.

Smith, D. G. (1984). "Vibracoring fluvial and deltaic sediments; tips on improving penetration and recovery." Journal of Sedimentary Petrology 54(2): 660-663. 
Smith, D. G. (1987). “A mini-vibracoring system.” Journal of Sedimentary Petrology 57(4): 757758.

Smits, A. D., M. K. Harris, D. G. Jackson and K. L. Hawkins (1998). Baseline Mapping Study of the Steed Pond Aquifer and Crouch Branch Confining Unit Beneath A/M Area, Savannah River Site, Aiken, South Carolina (U). Technical Report WSRC-TR-98-00357. Westinghouse Savannah River Company, Aiken, South Carolina 29808.

Thompson, T. A., C. S. Miller, P. K. Doss, L. D. Thompson and S. J. Baedke (1991). Lanbased vibracoring and vibracore analysis; tips, tricks, and traps. Occasional Paper Indiana Geological Survey, Bloomington, In.

Tunlid, A. and D. C. White (1991). Biochemical analysis of biomass, community structure, nutritional status and metabolic activity of the microbial communities in soil. Soil Biochemistry. J. M. Bollag and G. Stotzky. 7: 229-262.

Vroblesky, D. A. and W. T. Hyde (1997). "Diffusion samplers as an inexpensive approach to monitoring VOCs in ground water." Ground Water Monitoring and Remediation 17(3): 177-184.

Vroblesky, D. A., C. T. Nietch, J. F. Robertson, P. M. Bradley, J. Coates and J. T. Morris (1999). Natural attenuation potential of chlorinated volatile organic compounds in ground water, TNX flood plain, Savannah River Site, South Carolina. Water-Resources Investigations Report 99-4071. U.S. Geological Survey, Columbia, South Carolina.

Vroblesky, D. A., L. C. Rhodes and J. F. Robertson (1996). "Locating VOC contamination in a fractured-rock aquifer at the ground-water/surface-water interface using passive vapor collectors." Ground-Water 34: 223-30.

White, R. M. (1999). Airlift Recirculation Well Final Report - Southern Sector (U). Technical Report WSRC-TR-98-00428. Westinghouse Savannah River Company, Aiken, South Carolina 29808.

Winter, T. C., J. W. Harvey, O. L. Franke and W. M. Alley (1998). Ground water and surface water a single resource. U.S. Geological Circular 1139. U.S. Geological Survey, Denver, Colorado. 


\section{Appedices:}

Hydrograph Separation Summary Tables for Station 02197306 and 02197309

Monitoring Well Construction and Installation Reports

Estimate of Mass-Flux to Hyporheic Zone Near Road 2 
Hydrograph Separation Summary Tables for Station 02197306 and 02197309 
Hydrograph separation by the fixed interval method

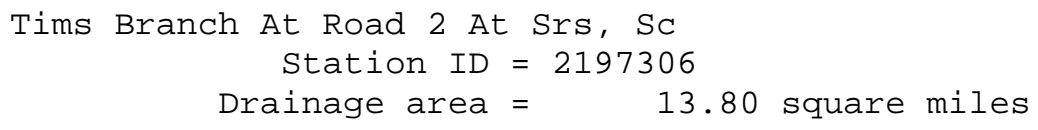

Period ending in 1994

\begin{tabular}{|c|c|c|c|c|c|c|c|c|}
\hline & $\begin{array}{l}\text { Mean } \\
\text { stream- } \\
\text { flow } \\
\text { (ft3/s) }\end{array}$ & $\begin{array}{l}\text { Mean } \\
\text { base } \\
\text { flow } \\
\text { (ft3/s) }\end{array}$ & $\begin{array}{l}\text { Mean } \\
\text { surface } \\
\text { runoff } \\
\text { (ft3/s) }\end{array}$ & $\begin{array}{c}\text { Total } \\
\text { stream- } \\
\text { flow } \\
\text { (in) }\end{array}$ & $\begin{array}{c}\text { Total } \\
\text { base } \\
\text { flow } \\
\text { (in) }\end{array}$ & $\begin{array}{c}\text { Total } \\
\text { surface } \\
\text { runoff } \\
\text { (in) }\end{array}$ & $\begin{array}{c}\mathrm{BF} / \\
\text { stream- } \\
\text { flow } \\
\left(\frac{\circ}{0}\right) \\
-----\end{array}$ & $\begin{array}{c}\text { Base } \\
\text { flow } \\
\text { (Mgal/d) }\end{array}$ \\
\hline Oct. & 3.76 & 2.73 & 1.04 & 0.314 & 0.228 & 0.087 & 72.47 & 1.761 \\
\hline Nov. & 3.74 & 3.44 & 0.30 & 0.303 & 0.278 & 0.024 & 91.99 & 2.225 \\
\hline Dec. & 3.69 & 3.46 & 0.23 & 0.308 & 0.289 & 0.019 & 93.79 & 2.235 \\
\hline Jan. & 3.81 & 3.36 & 0.44 & 0.318 & 0.281 & 0.037 & 88.39 & 2.174 \\
\hline Feb. & 4.24 & 3.19 & 1.05 & 0.320 & 0.240 & 0.080 & 75.15 & 2.059 \\
\hline Mar. & 4.66 & 3.16 & 1.51 & 0.390 & 0.264 & 0.126 & 67.70 & 2.041 \\
\hline Apr. & 2.55 & 2.50 & 0.04 & 0.206 & 0.202 & 0.004 & 98.30 & 1.618 \\
\hline May & 1.92 & 1.86 & 0.06 & 0.160 & 0.155 & 0.005 & 96.81 & 1.201 \\
\hline June & 2.20 & 1.83 & 0.37 & 0.178 & 0.148 & 0.030 & 83.18 & 1.183 \\
\hline July & 2.74 & 2.14 & 0.61 & 0.229 & 0.178 & 0.051 & 77.88 & 1.380 \\
\hline Aug. & 2.29 & 1.86 & 0.43 & 0.191 & 0.156 & 0.036 & 81.41 & 1.205 \\
\hline \multirow[t]{2}{*}{ Sept. } & 1.84 & 1.75 & 0.09 & 0.149 & 0.141 & 0.008 & 94.93 & 1.129 \\
\hline & 3.12 & 2.60 & 0.51 & 3.066 & 2.561 & 0.504 & 83.54 & 1.683 \\
\hline
\end{tabular}


Hydrograph separation by the fixed interval method

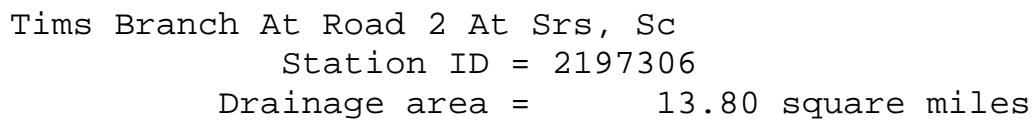

Period ending in 1995

\begin{tabular}{|c|c|c|c|c|c|c|c|c|}
\hline & $\begin{array}{l}\text { Mean } \\
\text { stream- } \\
\text { flow } \\
(\text { ft } 3 / s)\end{array}$ & $\begin{array}{l}\text { Mean } \\
\text { base } \\
\text { flow } \\
\text { (ft3/s) }\end{array}$ & $\begin{array}{l}\text { Mean } \\
\text { surface } \\
\text { runoff } \\
(\mathrm{ft} 3 / \mathrm{s})\end{array}$ & $\begin{array}{l}\text { Total } \\
\text { stream- } \\
\text { flow } \\
\text { (in) }\end{array}$ & $\begin{array}{l}\text { Total } \\
\text { base } \\
\text { flow } \\
\text { (in) }\end{array}$ & $\begin{array}{c}\text { Total } \\
\text { surface } \\
\text { runoff } \\
\text { (in) }\end{array}$ & $\begin{array}{c}\mathrm{BF} / \\
\text { stream- } \\
\text { flow } \\
\left(\frac{\circ}{0}\right)\end{array}$ & $\begin{array}{c}\text { Base } \\
\text { flow } \\
\text { (Mgal/d) }\end{array}$ \\
\hline & ------ & ----- & ----- & ------- & ------ & ------ & ----- & \\
\hline Oct. & 3.73 & 2.55 & 1.18 & 0.312 & 0.213 & 0.098 & 68.45 & 1.651 \\
\hline Nov. & 2.17 & 1.96 & 0.21 & 0.176 & 0.158 & 0.017 & 90.18 & 1.267 \\
\hline Dec. & 2.45 & 2.11 & 0.33 & 0.204 & 0.177 & 0.028 & 86.41 & 1.365 \\
\hline Jan. & 5.05 & 2.40 & 2.65 & 0.422 & 0.201 & 0.222 & 47.54 & 1.553 \\
\hline Feb. & 5.84 & 3.75 & 2.09 & 0.441 & 0.283 & 0.157 & 64.28 & 2.426 \\
\hline Mar. & 3.89 & 2.96 & 0.93 & 0.325 & 0.247 & 0.078 & 76.06 & 1.914 \\
\hline Apr. & 2.33 & 2.22 & 0.11 & 0.189 & 0.180 & 0.009 & 95.29 & 1.437 \\
\hline May & 1.67 & 1.49 & 0.17 & 0.139 & 0.125 & 0.015 & 89.56 & 0.965 \\
\hline June & 5.16 & 2.57 & 2.59 & 0.417 & 0.208 & 0.210 & 49.77 & 1.661 \\
\hline July & 2.40 & 2.09 & 0.30 & 0.200 & 0.175 & 0.025 & 87.35 & 1.353 \\
\hline Aug. & 2.79 & 1.42 & 1.37 & 0.233 & 0.119 & 0.114 & 50.88 & 0.917 \\
\hline \multirow[t]{2}{*}{ sept. } & 4.52 & 2.75 & 1.76 & 0.365 & 0.223 & 0.143 & 60.96 & 1.779 \\
\hline & 3.48 & 2.35 & $\begin{array}{l}---- \\
1.13\end{array}$ & 3.424 & 2.308 & 1.116 & $\begin{array}{l}----- \\
67.42\end{array}$ & 1.516 \\
\hline
\end{tabular}


Hydrograph separation by the fixed interval method

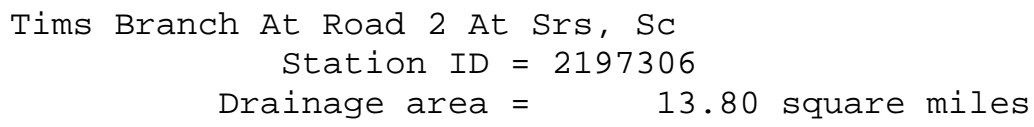

\begin{tabular}{|c|c|c|c|c|c|c|c|c|}
\hline & $\begin{array}{l}\text { Mean } \\
\text { stream- } \\
\text { flow } \\
\text { (ft } 3 / s \text { ) }\end{array}$ & $\begin{array}{l}\text { Mean } \\
\text { base } \\
\text { flow } \\
\text { (ft3/s) }\end{array}$ & $\begin{array}{l}\text { Mean } \\
\text { surface } \\
\text { runoff } \\
(\mathrm{ft} 3 / \mathrm{s})\end{array}$ & $\begin{array}{l}\text { Total } \\
\text { stream- } \\
\text { flow } \\
\text { (in) }\end{array}$ & $\begin{array}{c}\text { Total } \\
\text { base } \\
\text { flow } \\
\text { (in) }\end{array}$ & $\begin{array}{c}\text { Total } \\
\text { surface } \\
\text { runoff } \\
\text { (in) }\end{array}$ & $\begin{array}{c}\mathrm{BF} / \\
\text { stream- } \\
\text { flow } \\
\left(\frac{\circ}{0}\right)\end{array}$ & $\begin{array}{c}\text { Base } \\
\text { flow } \\
\text { (Mgal/d) }\end{array}$ \\
\hline & ----- & ---- & ---- & ----- & ----- & ----- & ----- & 0 \\
\hline Oct. & 2.71 & 2.32 & 0.39 & 0.226 & 0.194 & 0.032 & 85.70 & 1.499 \\
\hline Nov. & 2.82 & 2.29 & 0.53 & 0.228 & 0.185 & 0.043 & 81.32 & 1.482 \\
\hline Dec. & 3.55 & 2.66 & 0.89 & 0.297 & 0.223 & 0.074 & 75.02 & 1.722 \\
\hline Jan. & 3.50 & 2.77 & 0.73 & 0.292 & 0.231 & 0.061 & 79.15 & 1.789 \\
\hline Feb. & 3.31 & 2.96 & 0.36 & 0.259 & 0.231 & 0.028 & 89.28 & 1.912 \\
\hline Mar. & 3.96 & 3.33 & 0.63 & 0.331 & 0.278 & 0.053 & 84.12 & 2.153 \\
\hline Apr. & 2.80 & 2.14 & 0.66 & 0.226 & 0.173 & 0.053 & 76.40 & 1.381 \\
\hline May & 2.01 & 1.75 & 0.26 & 0.168 & 0.147 & 0.022 & 87.18 & 1.134 \\
\hline June & 2.04 & 1.82 & 0.23 & 0.165 & 0.147 & 0.018 & 88.91 & 1.174 \\
\hline July & 2.78 & 1.99 & 0.79 & 0.233 & 0.167 & 0.066 & 71.61 & 1.288 \\
\hline Aug. & 2.45 & 1.74 & 0.71 & 0.204 & 0.145 & 0.059 & 71.11 & 1.124 \\
\hline \multirow[t]{2}{*}{ Sept. } & 1.58 & 1.12 & 0.47 & 0.128 & 0.090 & 0.038 & 70.39 & 0.721 \\
\hline & 2.80 & 2.24 & 0.55 & 2.757 & 2.211 & 0.546 & $\begin{array}{l}--18 \\
80.18\end{array}$ & 1.448 \\
\hline
\end{tabular}




Annual base-flow summary
Tims Branch At Road 2 At Srs, Sc
Station ID $=2197306$
Drainage area $=$
Fixed interval method
Year starts in October
Year ends in September
Period
ending

Seasonal-distribution table

Tims Branch At Road 2 At Srs, Sc

Station ID $=2197306$

Drainage area $=\quad 13.80$ square miles

Fixed interval method

Year starts in October

Year ends in september

$\begin{array}{lcc}\text { Month } & \begin{array}{c}\text { Base flow } \\ \text { (in) }\end{array} & \begin{array}{c}\text { Runoff } \\ \text { (in) }\end{array} \\ ------- & ------- & ----- \\ \text { October } & 0.212 & 0.072 \\ \text { November } & 0.207 & 0.028 \\ \text { December } & 0.229 & 0.040 \\ \text { January } & 0.238 & 0.106 \\ \text { February } & 0.252 & 0.088 \\ \text { March } & 0.263 & 0.085 \\ \text { April } & 0.185 & 0.022 \\ \text { May } & 0.142 & 0.014 \\ \text { June } & 0.168 & 0.086 \\ \text { July } & 0.173 & 0.047 \\ \text { August } & 0.140 & 0.070 \\ \text { September } & 0.151 & 0.063\end{array}$


Hydrograph separation by the fixed interval method

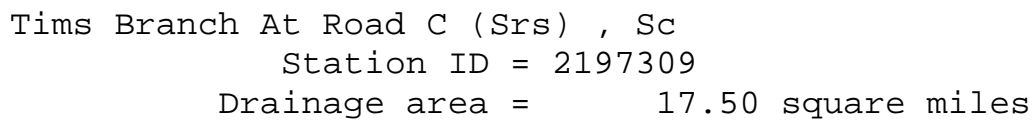

\begin{tabular}{|c|c|c|c|c|c|c|c|c|}
\hline & $\begin{array}{l}\text { Mean } \\
\text { stream- } \\
\text { flow } \\
\text { (ft3/s) }\end{array}$ & $\begin{array}{l}\text { Mean } \\
\text { base } \\
\text { flow } \\
\text { (ft3/s) }\end{array}$ & $\begin{array}{l}\text { Mean } \\
\text { surface } \\
\text { runoff } \\
(\mathrm{ft} 3 / \mathrm{s})\end{array}$ & $\begin{array}{c}\text { Total } \\
\text { stream- } \\
\text { flow } \\
(\text { in) }\end{array}$ & $\begin{array}{l}\text { Total } \\
\text { base } \\
\text { flow } \\
\text { (in) }\end{array}$ & $\begin{array}{c}\text { Total } \\
\text { surface } \\
\text { runoff } \\
(\text { in) }\end{array}$ & $\begin{array}{l}\mathrm{BF} / \\
\text { stream- } \\
\text { flow } \\
\left(\frac{\circ}{\circ}\right)\end{array}$ & $\begin{array}{c}\text { Base } \\
\text { flow } \\
\text { (Mgal/d) }\end{array}$ \\
\hline Oct. & 6.58 & 4.75 & 1.83 & 0.433 & 0.313 & 0.121 & 72.14 & 3.066 \\
\hline Nov. & 6.89 & 6.18 & 0.71 & 0.439 & 0.394 & 0.045 & 89.74 & 3.994 \\
\hline Dec. & 7.27 & 6.81 & 0.47 & 0.479 & 0.448 & 0.031 & 93.57 & 4.398 \\
\hline Jan. & 8.29 & 7.21 & 1.08 & 0.546 & 0.475 & 0.071 & 86.97 & 4.661 \\
\hline Feb. & 9.21 & 7.65 & 1.56 & 0.548 & 0.455 & 0.093 & 83.09 & 4.946 \\
\hline Mar. & 10.52 & 7.58 & 2.94 & 0.693 & 0.499 & 0.194 & 72.04 & 4.899 \\
\hline Apr. & 6.12 & 5.92 & 0.20 & 0.390 & 0.378 & 0.013 & 96.79 & 3.828 \\
\hline May & 4.73 & 4.49 & 0.24 & 0.312 & 0.296 & 0.016 & 95.02 & 2.904 \\
\hline June & 5.22 & 4.41 & 0.81 & 0.333 & 0.281 & 0.052 & 84.43 & 2.850 \\
\hline July & 5.57 & 4.65 & 0.92 & 0.367 & 0.307 & 0.061 & 83.51 & 3.008 \\
\hline Aug. & 5.17 & 4.33 & 0.84 & 0.340 & 0.285 & 0.055 & 83.71 & 2.795 \\
\hline Sept. & 3.58 & 3.41 & 0.17 & 0.228 & 0.217 & 0.011 & 95.34 & 2.204 \\
\hline & $\begin{array}{l}---- \\
6.59\end{array}$ & 5.61 & $\begin{array}{l}---- \\
0.98\end{array}$ & $\begin{array}{r}------- \\
5.110\end{array}$ & 4.349 & $\begin{array}{r}------- \\
0.761\end{array}$ & $\begin{array}{l}----- \\
85.11\end{array}$ & 3.623 \\
\hline
\end{tabular}


Hydrograph separation by the fixed interval method

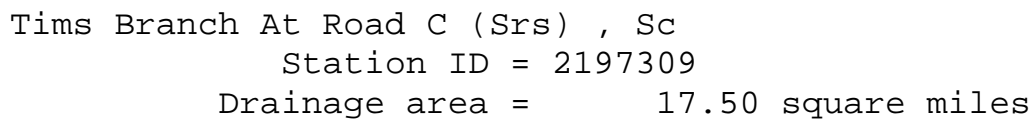

Period ending in 1995

\begin{tabular}{|c|c|c|c|c|c|c|c|c|}
\hline & $\begin{array}{l}\text { Mean } \\
\text { stream- } \\
\text { flow } \\
(\mathrm{ft} 3 / \mathrm{s})\end{array}$ & $\begin{array}{l}\text { Mean } \\
\text { base } \\
\text { flow } \\
\text { (ft3/s) }\end{array}$ & $\begin{array}{l}\text { Mean } \\
\text { surface } \\
\text { runoff } \\
(\mathrm{ft} 3 / \mathrm{s})\end{array}$ & $\begin{array}{l}\text { Total } \\
\text { stream- } \\
\text { flow } \\
\text { (in) }\end{array}$ & $\begin{array}{l}\text { Total } \\
\text { base } \\
\text { flow } \\
\text { (in) }\end{array}$ & $\begin{array}{c}\text { Total } \\
\text { surface } \\
\text { runoff } \\
\text { (in) }\end{array}$ & $\begin{array}{c}\mathrm{BF} / \\
\text { stream- } \\
\text { flow } \\
\left(\frac{\circ}{0}\right)\end{array}$ & $\begin{array}{c}\text { Base } \\
\text { flow } \\
\text { (Mgal/d) }\end{array}$ \\
\hline & ----- & ----- & ---- & ----- & ----- & ----- & ----- & ----- \\
\hline Oct. & 8.35 & 6.12 & 2.23 & 0.550 & 0.403 & 0.147 & 73.34 & 3.956 \\
\hline Nov. & 5.26 & 4.73 & 0.53 & 0.336 & 0.302 & 0.034 & 89.87 & 3.057 \\
\hline Dec. & 6.60 & 5.36 & 1.24 & 0.435 & 0.353 & 0.082 & 81.24 & 3.467 \\
\hline Jan. & 8.01 & 5.80 & 2.20 & 0.527 & 0.382 & 0.145 & 72.48 & 3.750 \\
\hline Feb. & 11.26 & 7.25 & 4.01 & 0.670 & 0.432 & 0.238 & 64.41 & 4.687 \\
\hline Mar. & 8.13 & 7.07 & 1.06 & 0.536 & 0.466 & 0.070 & 86.94 & 4.567 \\
\hline Apr. & 5.38 & 5.11 & 0.27 & 0.343 & 0.326 & 0.017 & 94.92 & 3.302 \\
\hline May & 4.19 & 3.84 & 0.35 & 0.276 & 0.253 & 0.023 & 91.53 & 2.478 \\
\hline June & 9.03 & 6.01 & 3.02 & 0.575 & 0.383 & 0.192 & 66.58 & 3.884 \\
\hline July & 5.39 & 5.29 & 0.10 & 0.355 & 0.349 & 0.006 & 98.20 & 3.421 \\
\hline Aug. & 6.06 & 4.58 & 1.47 & 0.399 & 0.302 & 0.097 & 75.67 & 2.962 \\
\hline \multirow[t]{2}{*}{ Sept. } & 7.11 & 5.08 & 2.03 & 0.453 & 0.324 & 0.129 & 71.48 & 3.283 \\
\hline & 7.03 & 5.51 & 1.52 & 5.456 & 4.274 & 1.182 & 78.34 & 3.561 \\
\hline
\end{tabular}


Hydrograph separation by the fixed interval method

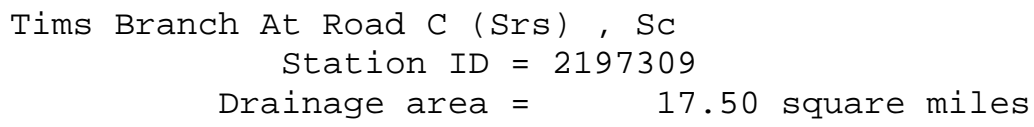

\begin{tabular}{|c|c|c|c|c|c|c|c|c|}
\hline & $\begin{array}{l}\text { Mean } \\
\text { stream- } \\
\text { flow } \\
\text { (ft } 3 / s \text { ) }\end{array}$ & $\begin{array}{l}\text { Mean } \\
\text { base } \\
\text { flow } \\
(\mathrm{ft} 3 / \mathrm{s})\end{array}$ & $\begin{array}{l}\text { Mean } \\
\text { surface } \\
\text { runoff } \\
(\mathrm{ft} 3 / \mathrm{s})\end{array}$ & $\begin{array}{l}\text { Total } \\
\text { stream- } \\
\text { flow } \\
\text { (in) }\end{array}$ & $\begin{array}{c}\text { Total } \\
\text { base } \\
\text { flow } \\
\text { (in) }\end{array}$ & $\begin{array}{l}\text { Total } \\
\text { surface } \\
\text { runoff } \\
\text { (in) }\end{array}$ & $\begin{array}{c}\mathrm{BF} / \\
\text { stream- } \\
\text { flow } \\
\left(\frac{\circ}{0}\right)\end{array}$ & $\begin{array}{c}\text { Base } \\
\text { flow } \\
\text { (Mgal/d) }\end{array}$ \\
\hline & ---- & ---- & ---- & ----- & ----- & ----- & ----- & 0 \\
\hline Oct. & 5.23 & 4.43 & 0.80 & 0.344 & 0.292 & 0.053 & 84.70 & 2.862 \\
\hline Nov. & 6.16 & 5.39 & 0.77 & 0.393 & 0.344 & 0.049 & 87.50 & 3.483 \\
\hline Dec. & 7.38 & 5.94 & 1.45 & 0.486 & 0.391 & 0.095 & 80.42 & 3.836 \\
\hline Jan. & 7.24 & 6.09 & 1.15 & 0.477 & 0.401 & 0.076 & 84.09 & 3.933 \\
\hline Feb. & 6.22 & 5.69 & 0.53 & 0.384 & 0.351 & 0.033 & 91.41 & 3.677 \\
\hline Mar. & 7.48 & 5.88 & 1.60 & 0.493 & 0.388 & 0.105 & 78.65 & 3.802 \\
\hline Apr. & 5.10 & 4.58 & 0.52 & 0.325 & 0.292 & 0.033 & 89.80 & 2.960 \\
\hline May & 4.18 & 3.66 & 0.51 & 0.275 & 0.241 & 0.034 & 87.72 & 2.368 \\
\hline June & 4.41 & 3.95 & 0.46 & 0.281 & 0.252 & 0.029 & 89.64 & 2.555 \\
\hline July & 5.24 & 4.65 & 0.59 & 0.345 & 0.307 & 0.039 & 88.80 & 3.008 \\
\hline Aug. & 6.16 & 5.00 & 1.16 & 0.406 & 0.330 & 0.076 & 81.20 & 3.233 \\
\hline \multirow[t]{2}{*}{ Sept. } & 5.15 & 4.21 & 0.94 & 0.328 & 0.268 & 0.060 & 81.75 & 2.721 \\
\hline & 5.83 & 4.96 & 0.88 & 4.538 & 3.856 & 0.682 & 84.97 & 3.203 \\
\hline
\end{tabular}




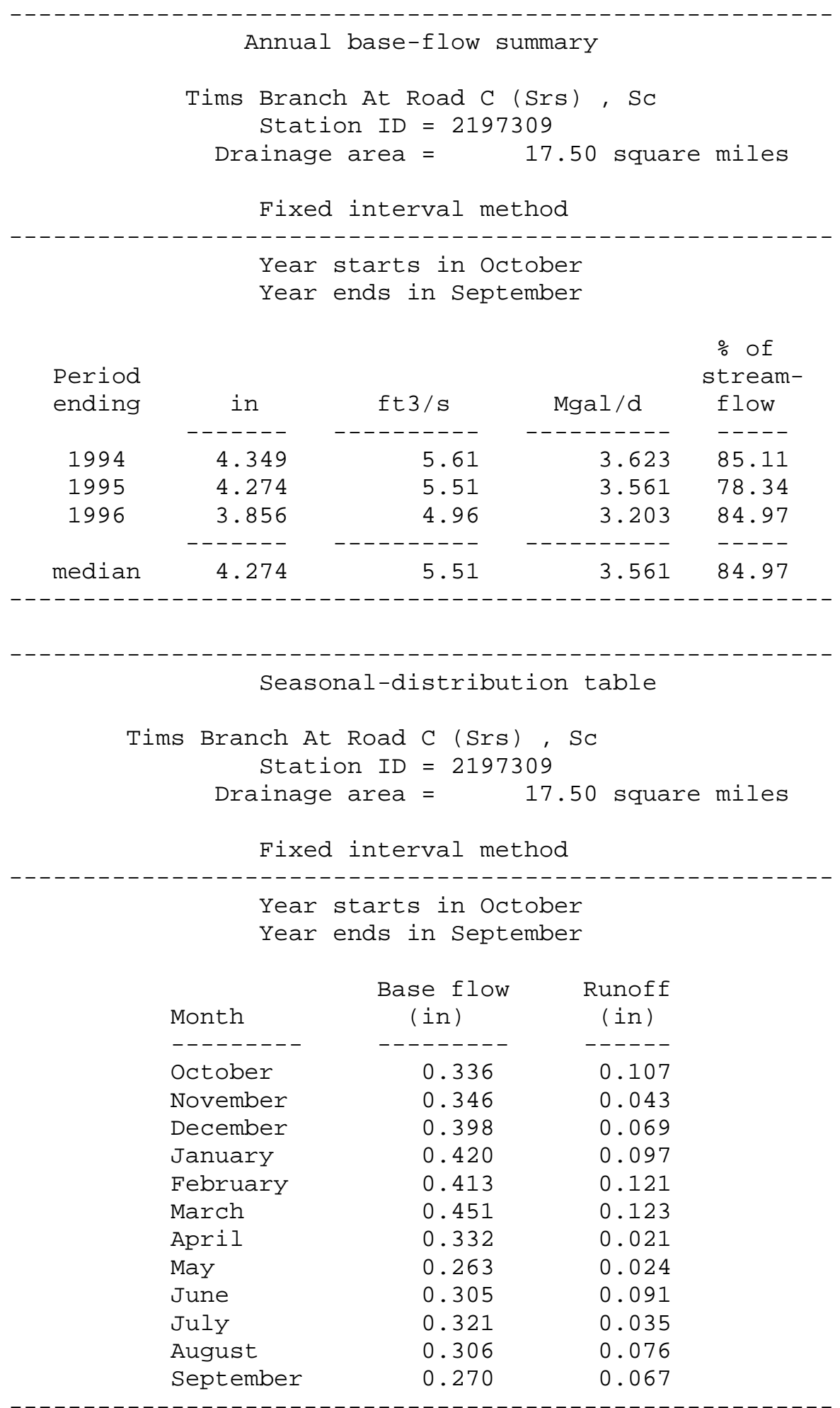


Monitoring Well Construction and Installation Reports 


\section{Monitoring Well Construction Diagram}

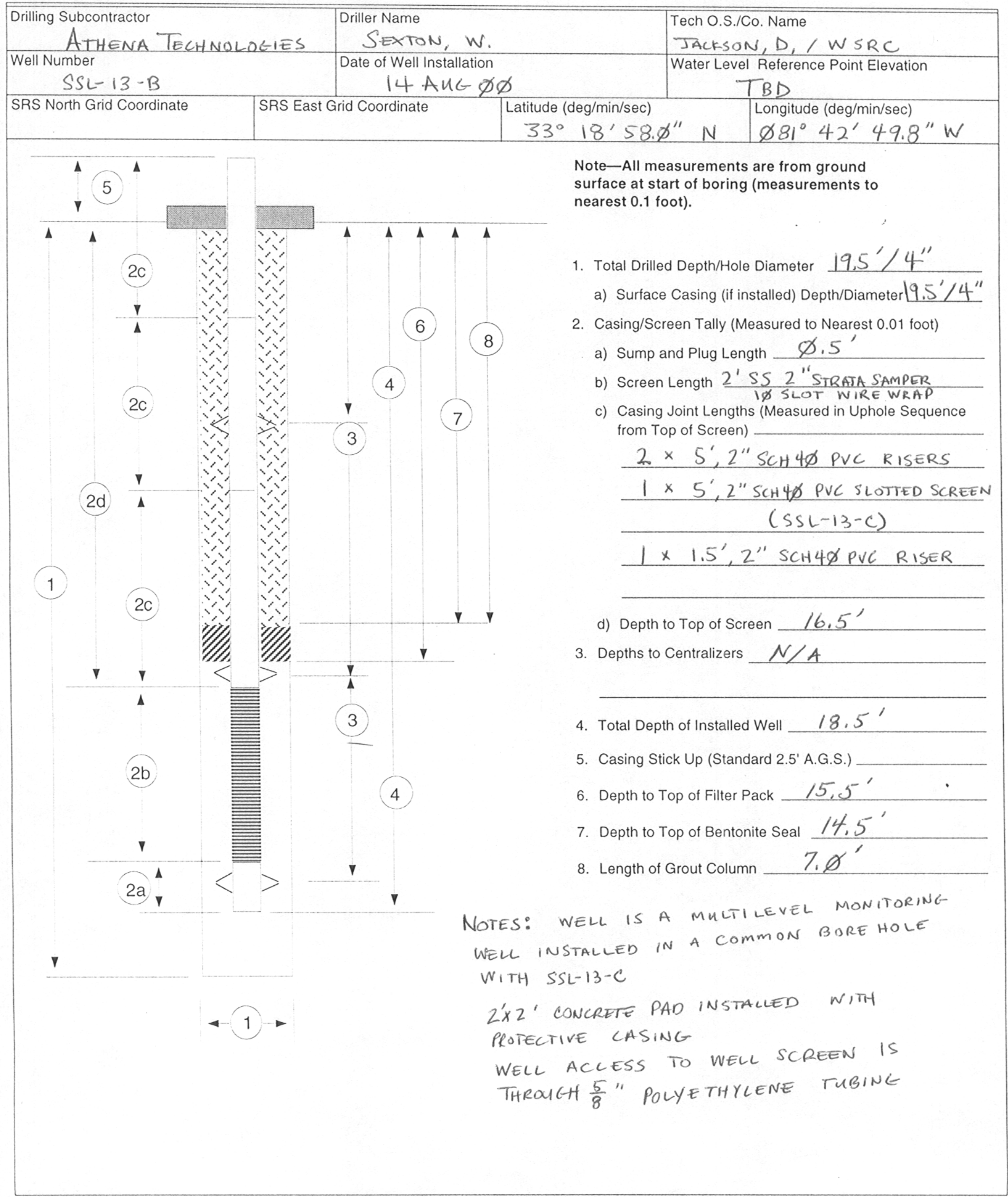




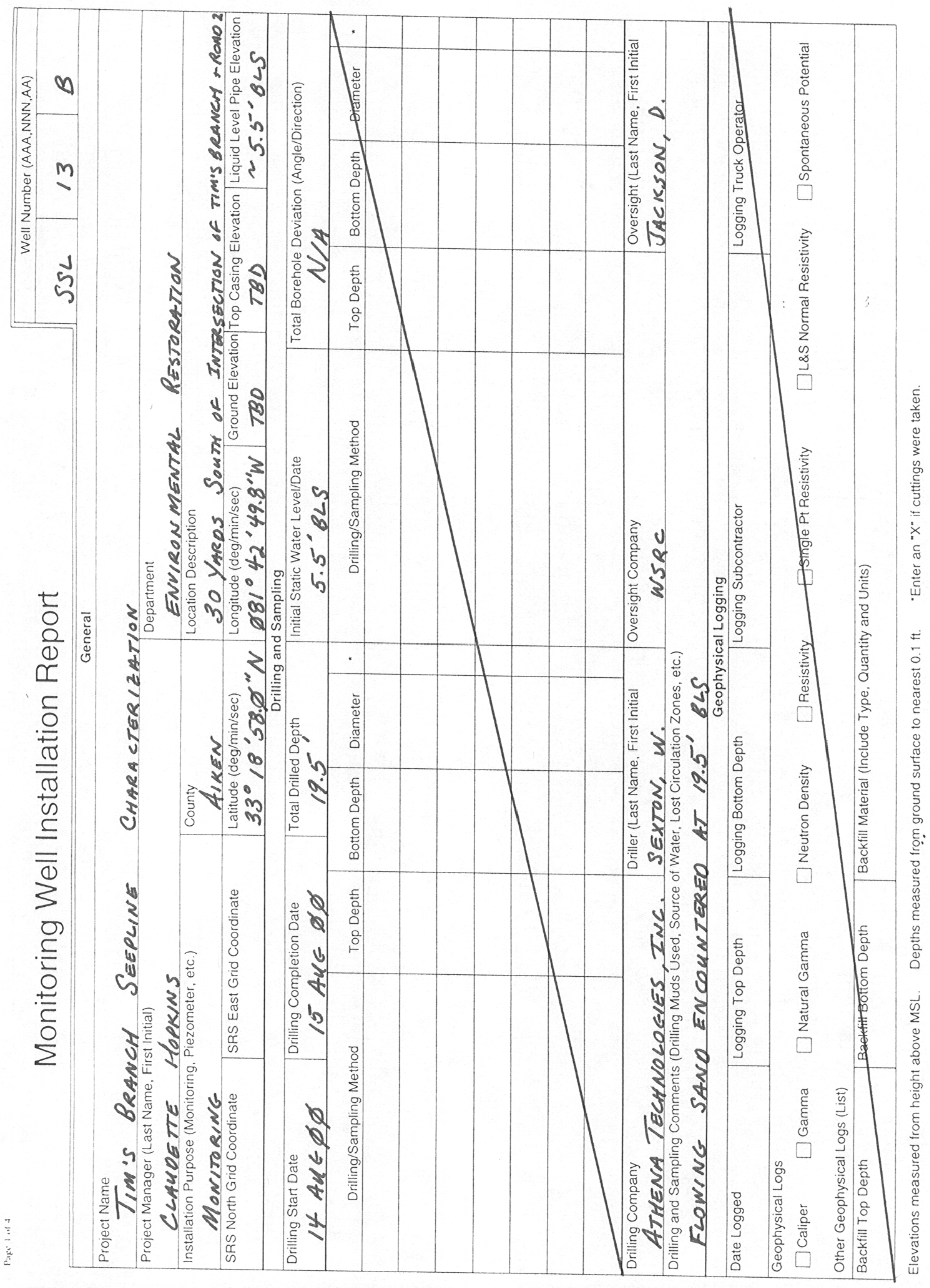



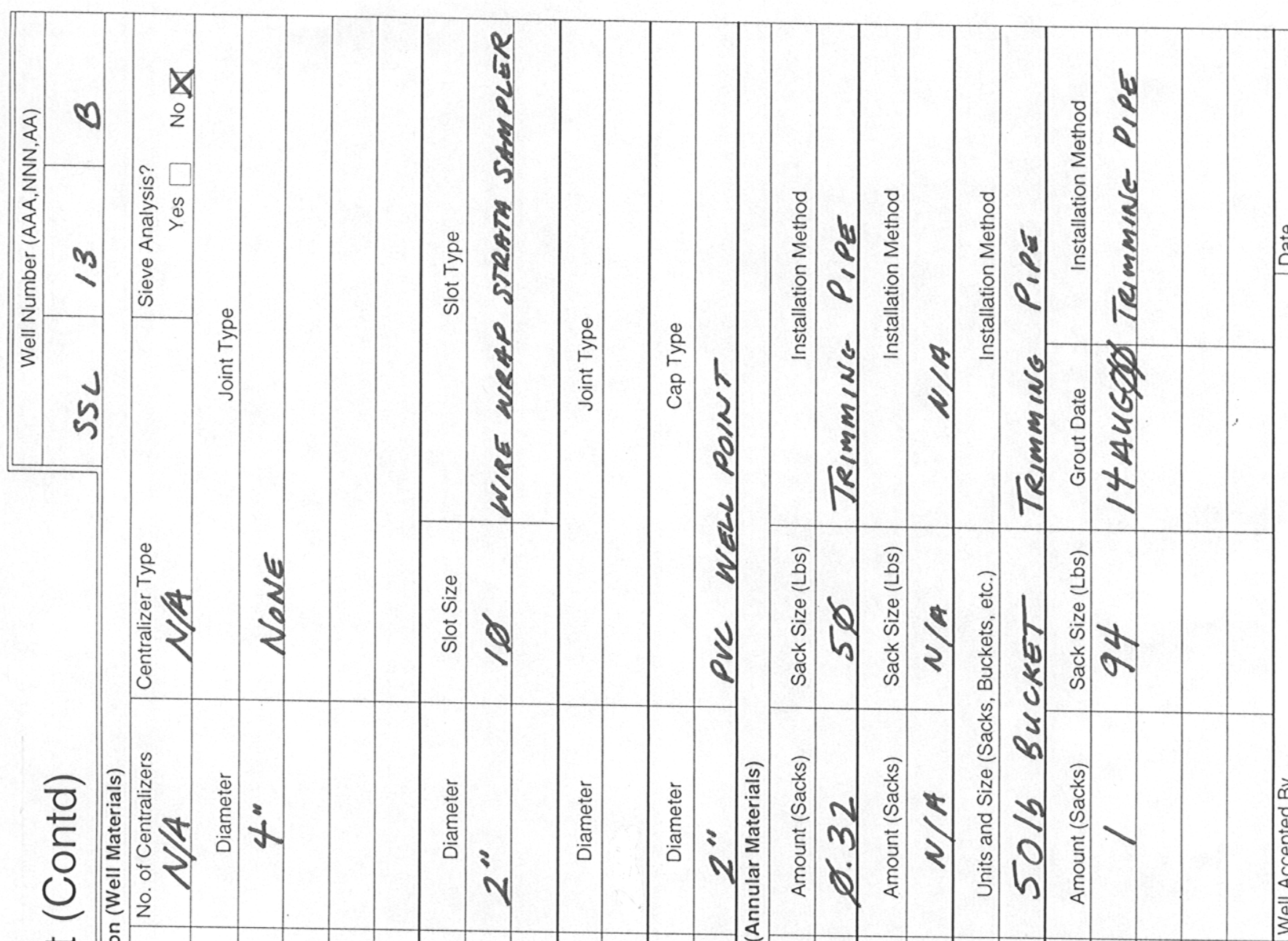

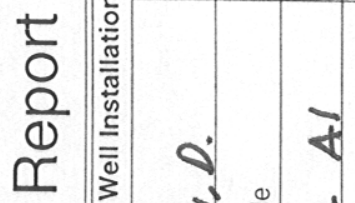

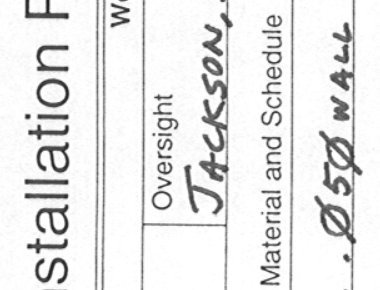

产

डे के के

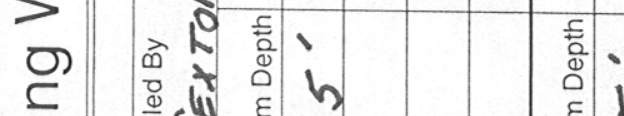

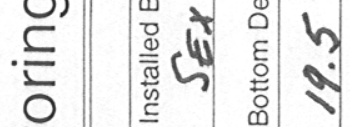
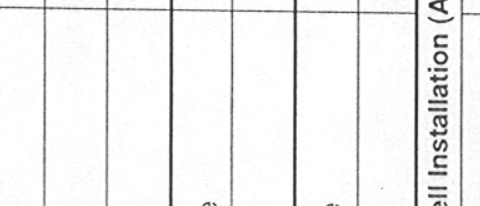

$\begin{array}{lll}\bar{\varepsilon} & \widehat{\varepsilon} \\ \text { है } & \text { है } \\ \text { है } & \end{array}$

va

है:

บิ

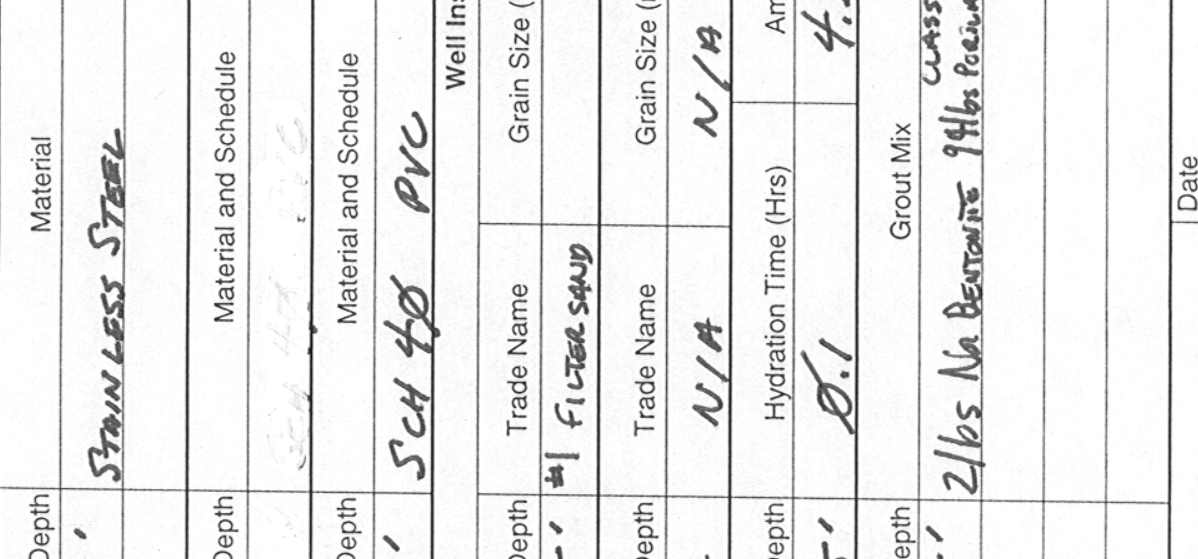

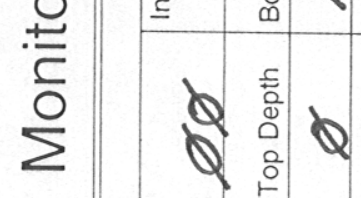

言约

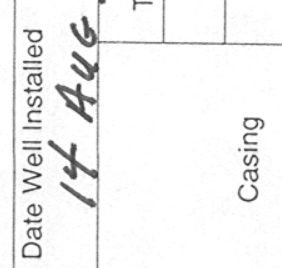

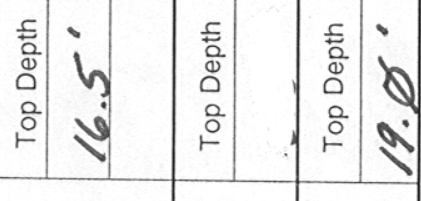

喜高高旁

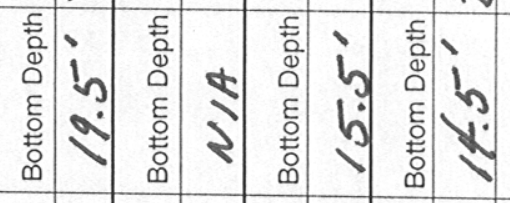

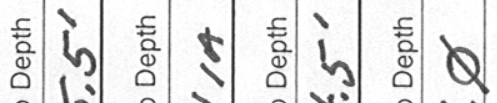

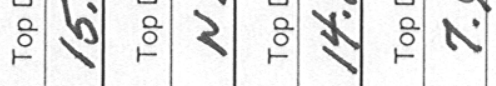




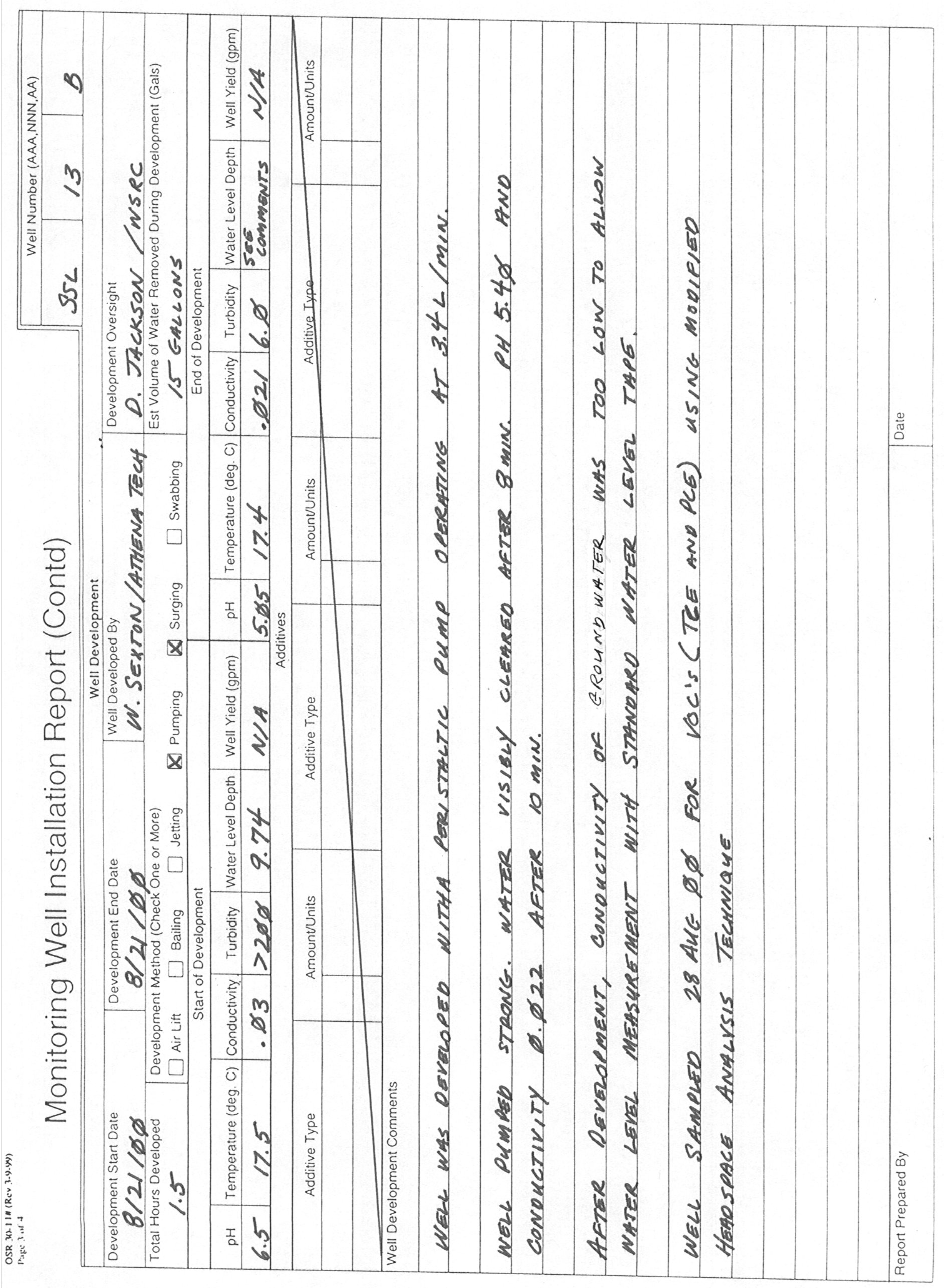




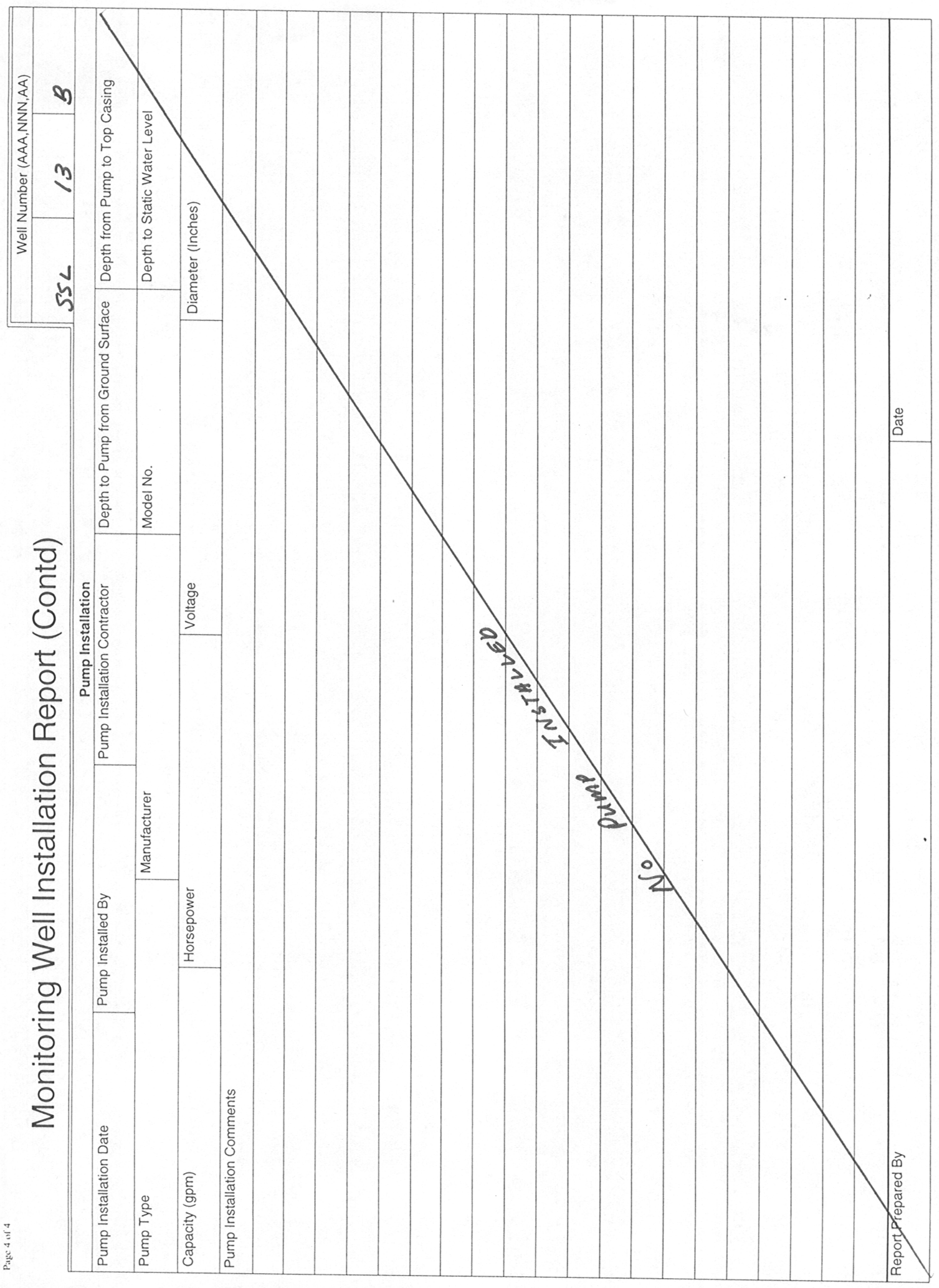


OSR 30-5\# (Rev 4-6-99)

Monitoring Well Construction Diagram

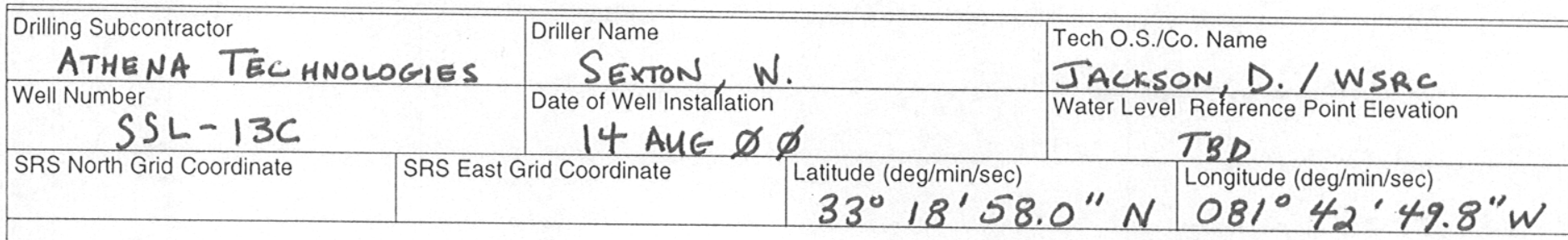

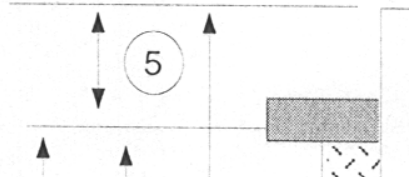

$2 c$

(ac)

(dd)

1

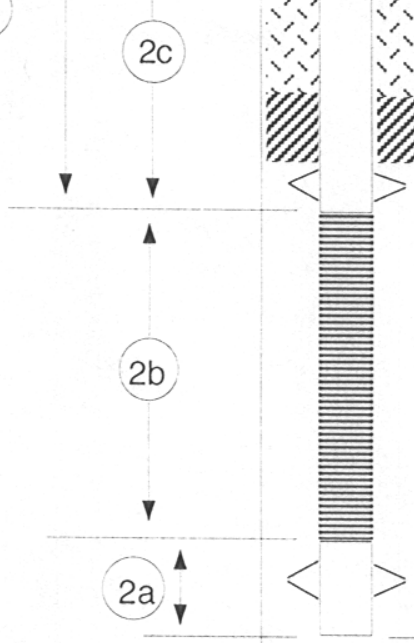

Note-All measurements are from ground surface at start of boring (measurements to nearest 0.1 foot)

1. Total Drilled Depth/Hole Diameter $19.5 \% 4^{\prime \prime}$

a) Surface Casing (if installed) Depth/Diameter $19.5 \% \mathrm{~s}^{\prime \prime}$

68

2. Casing/Screen Tally (Measured to Nearest 0.01 foot)

a) Sump and Plug Length $12.8^{\prime}$

b) Screen Length $\frac{5,2 \text { "SLOTJED PrC }}{10 \mathrm{SLOT}}$

c) Casing Joint Lengths (Measured in Uphole Sequence from Top of Screen) 1.512 - SCH 4O PrC

d) Depth to Top of Screen $1.5^{\prime}$

3. Depths to Centralizers N 14

4. Total Depth of Installed Well $18.5^{\prime}$

5. Casing Stick Up (Standard 2.5' A.G.S.)

6. Depth to Top of Filter Pack 1. er'

7. Depth to Top of Bentonite Seal $8.8{ }^{\prime}$

8. Length of Grout Column NONE NOTE: THIS IS A MULTILEVEL MONITORING WELL INSTALLED IN A COMMON BOREHOLE WITH SSLL/3-B ACCESS TO WELL SCREEN 15 THROUGH 5/8" DIAMETER POLYETHYLENE TUBING

WELLS WERE COMPLETED WITH PROTECTIVE CASING AND A $24 " \times 24$ " CONCRETE PAD. 

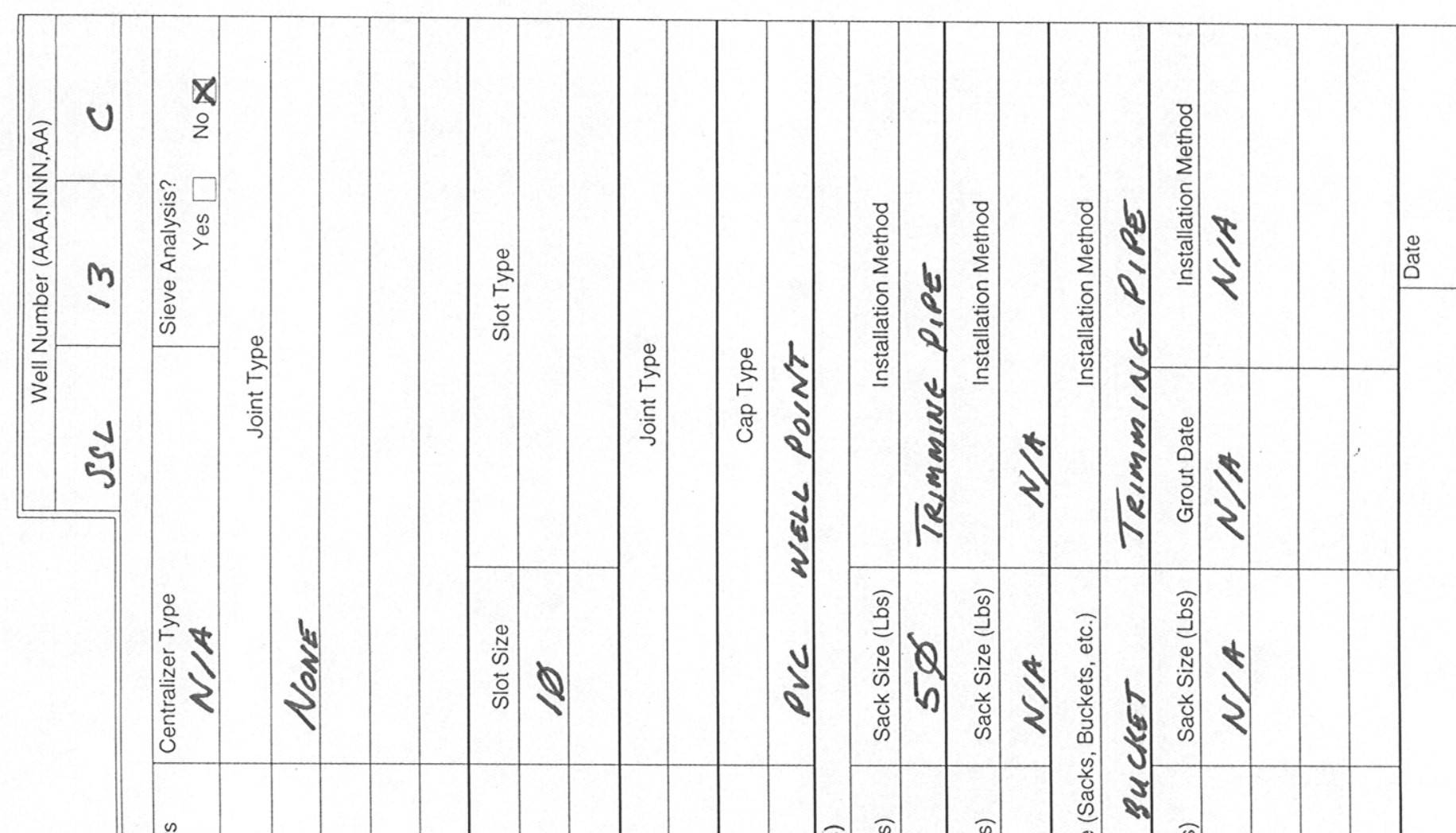

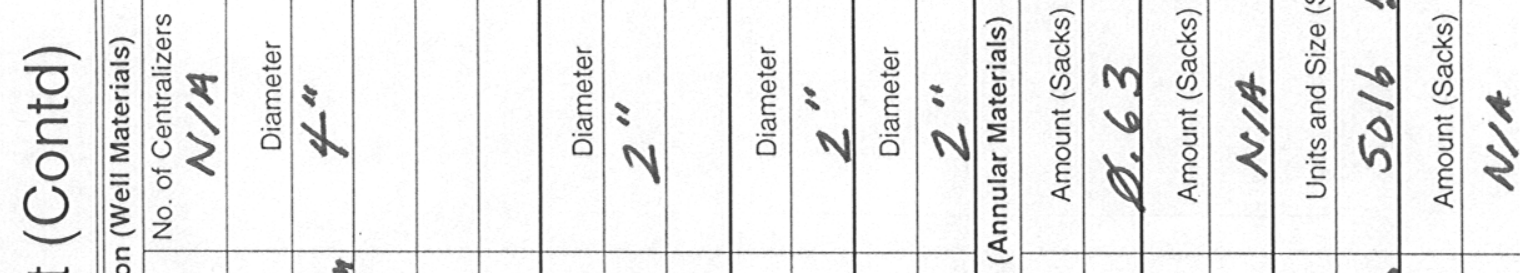

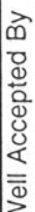

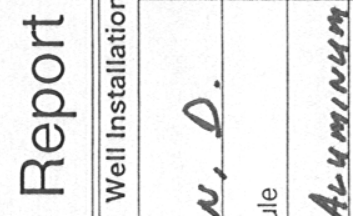

든

产

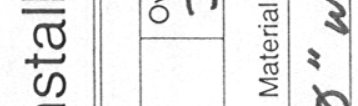

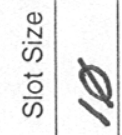

$=$ है

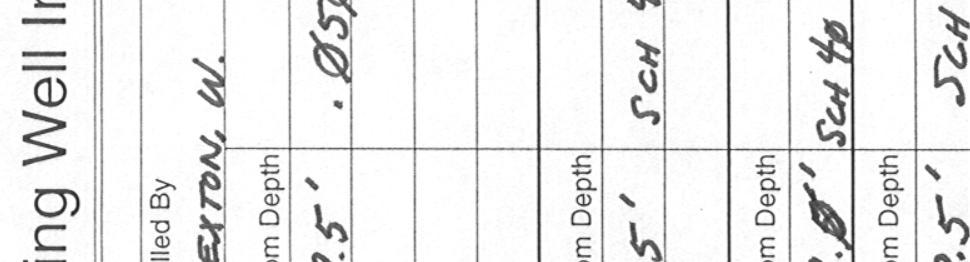

.

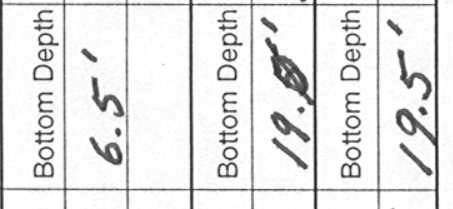

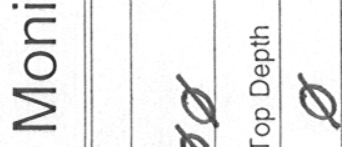

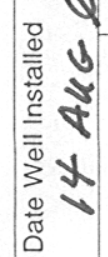

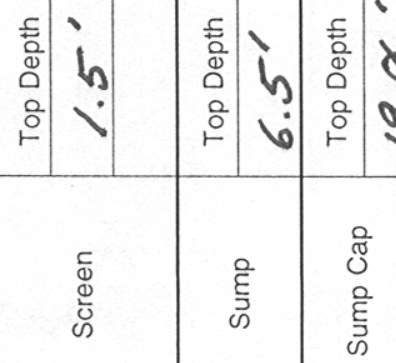

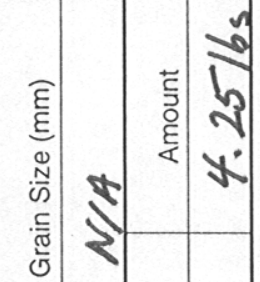

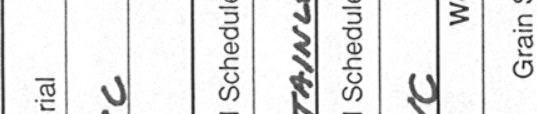

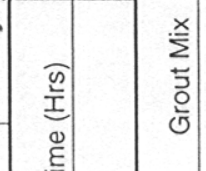

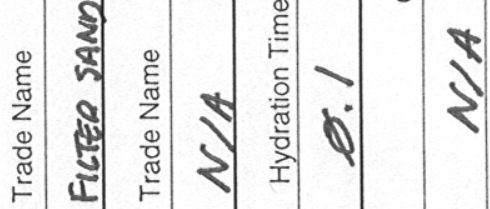

ฮั

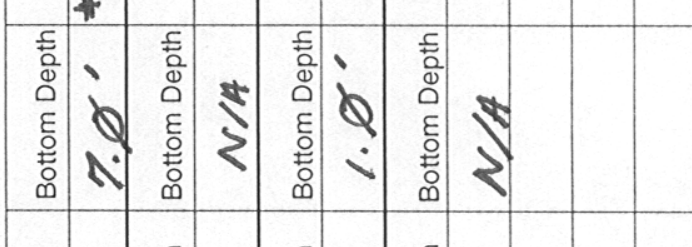

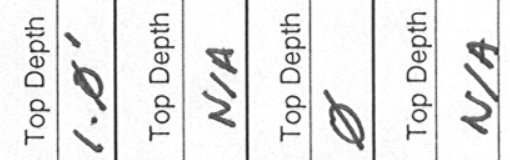

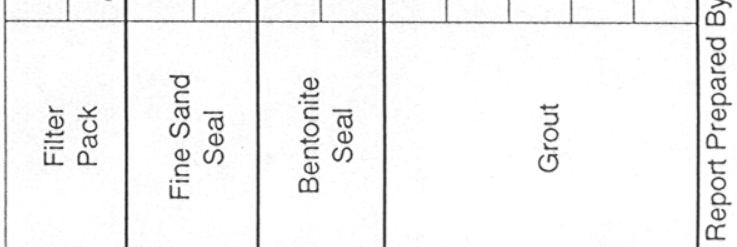




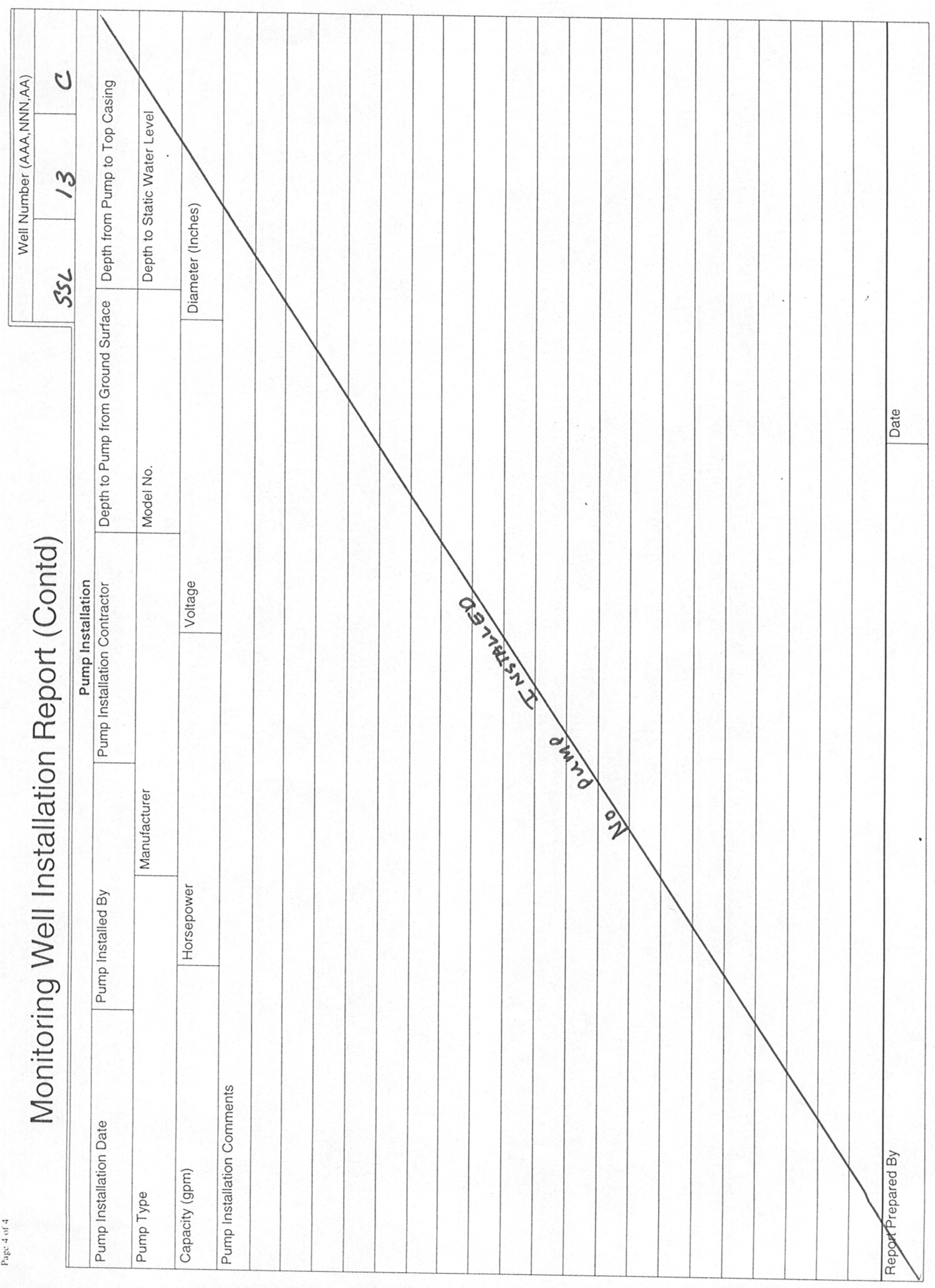




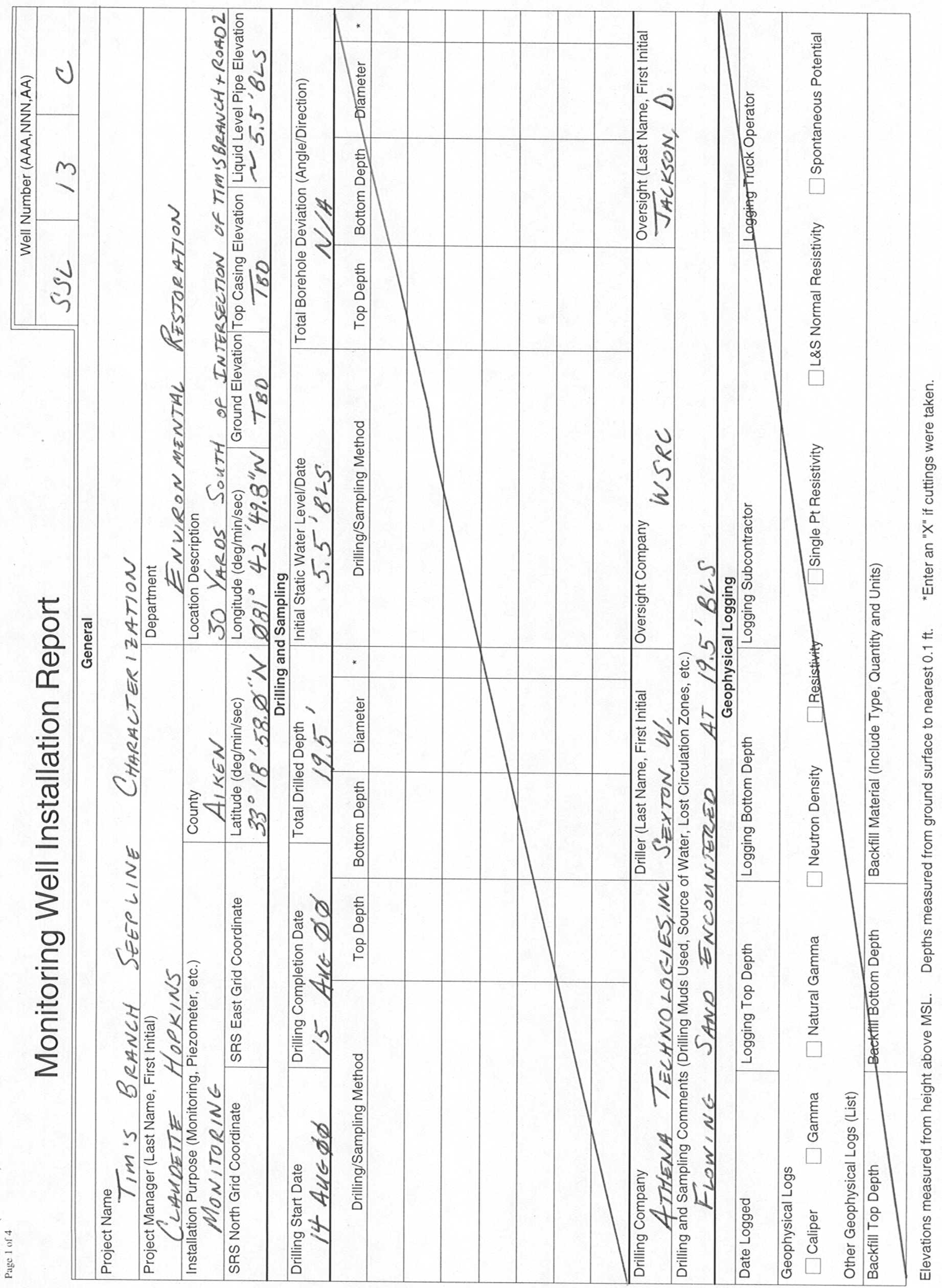




\section{Monitoring Well Construction Diagram}

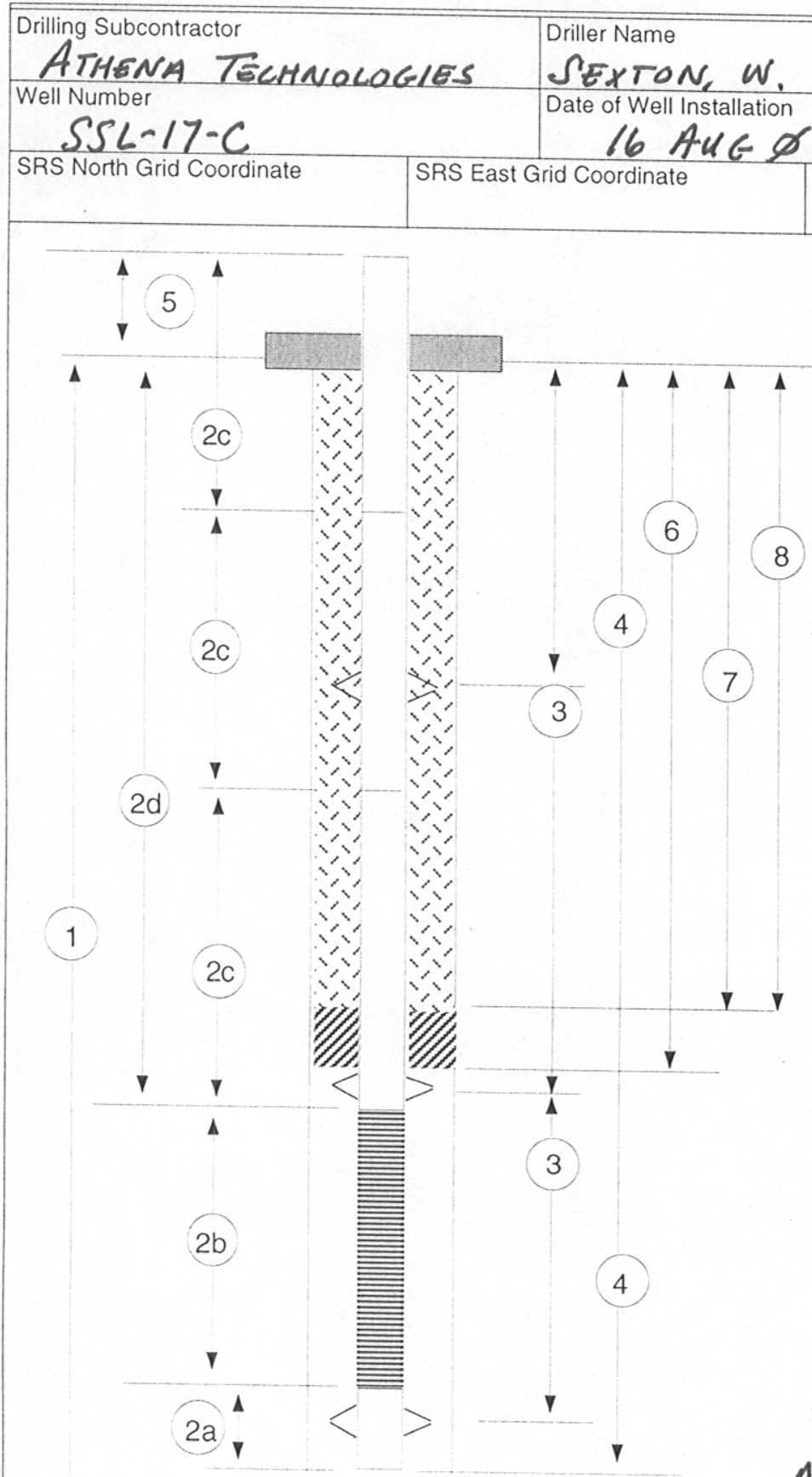

$\boldsymbol{\nabla}$

NOTE: WELL IS A MULTI-LEVEL MONITORING WELL INSTALLED IN A COMMON BOREHOLE WITH SSL $-17 B$

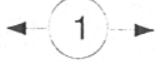

- 2x $2^{\prime}$ concrete pad installed WITH PROTECTIVE CASINE

- Access to well screen THROUGH $5 / 8$ " POLYETHYLENE TUBING 


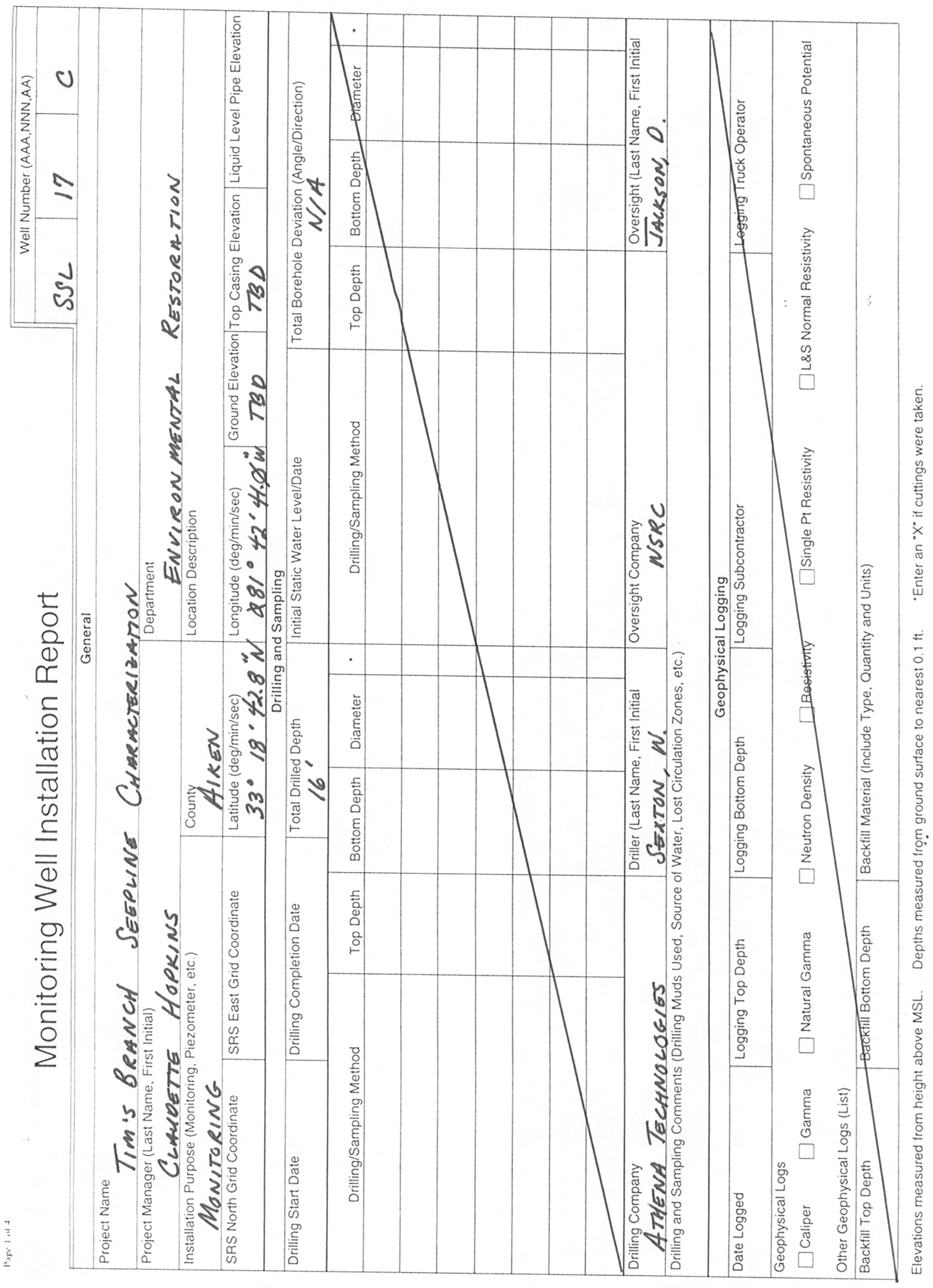




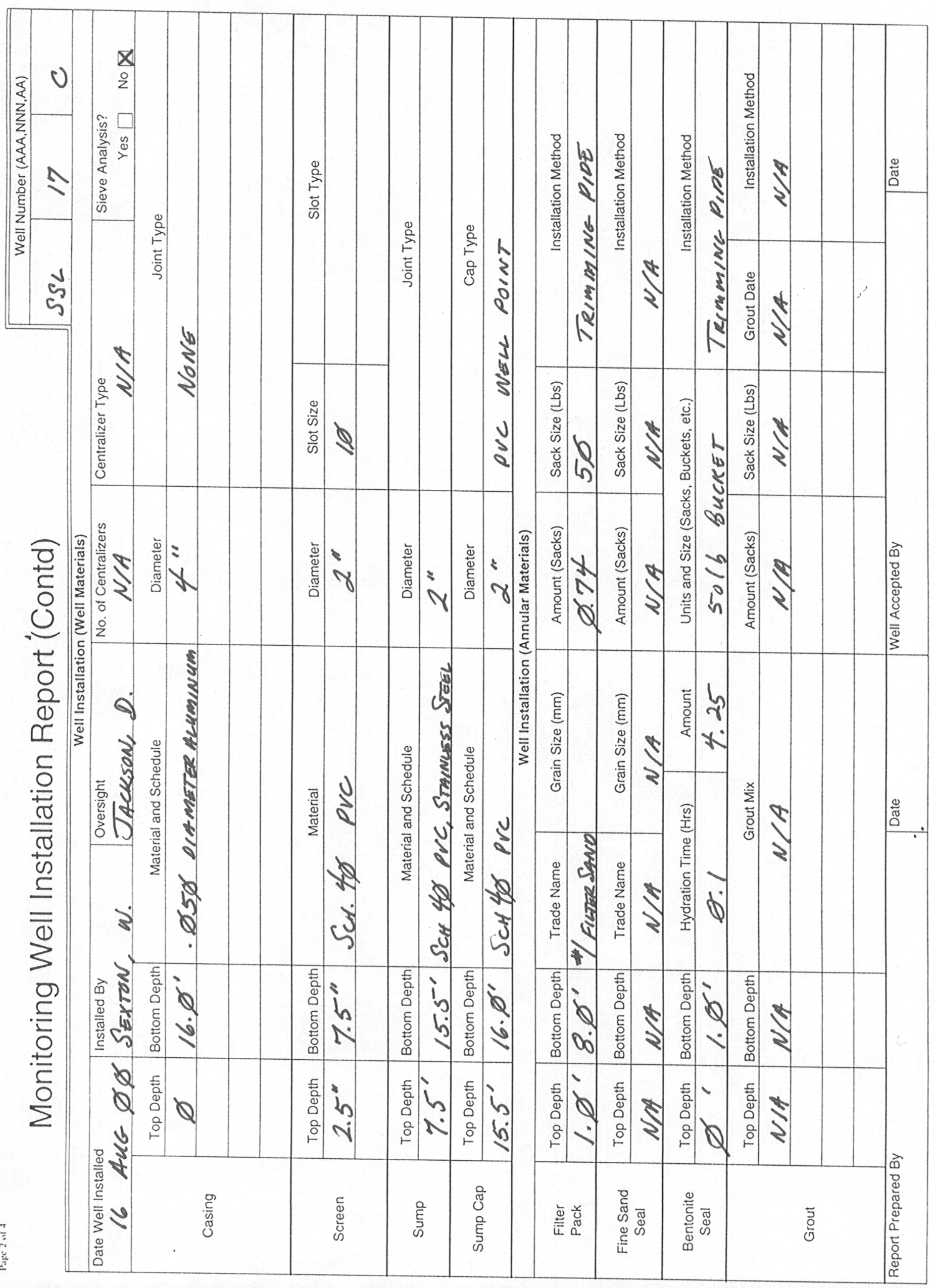




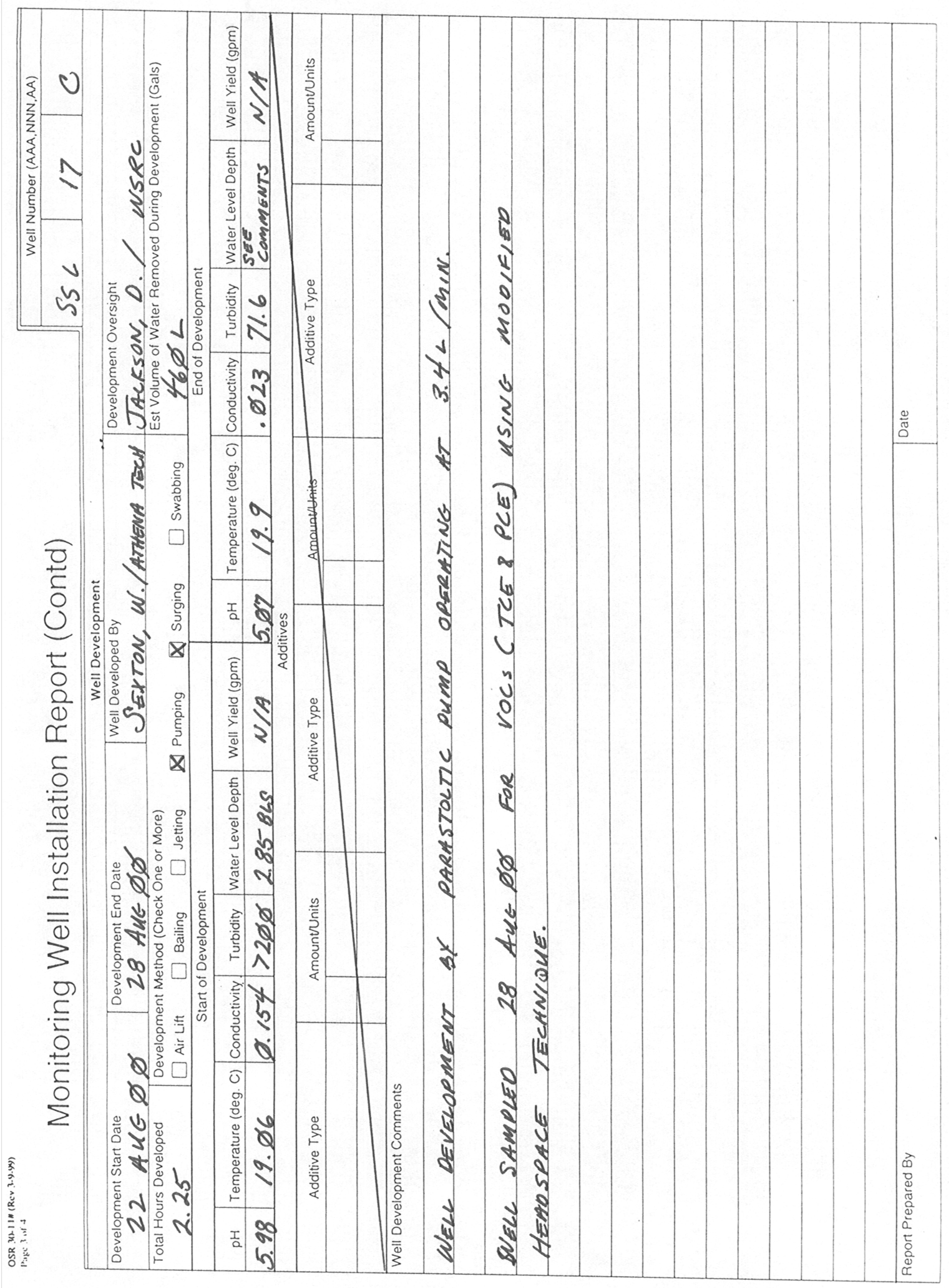




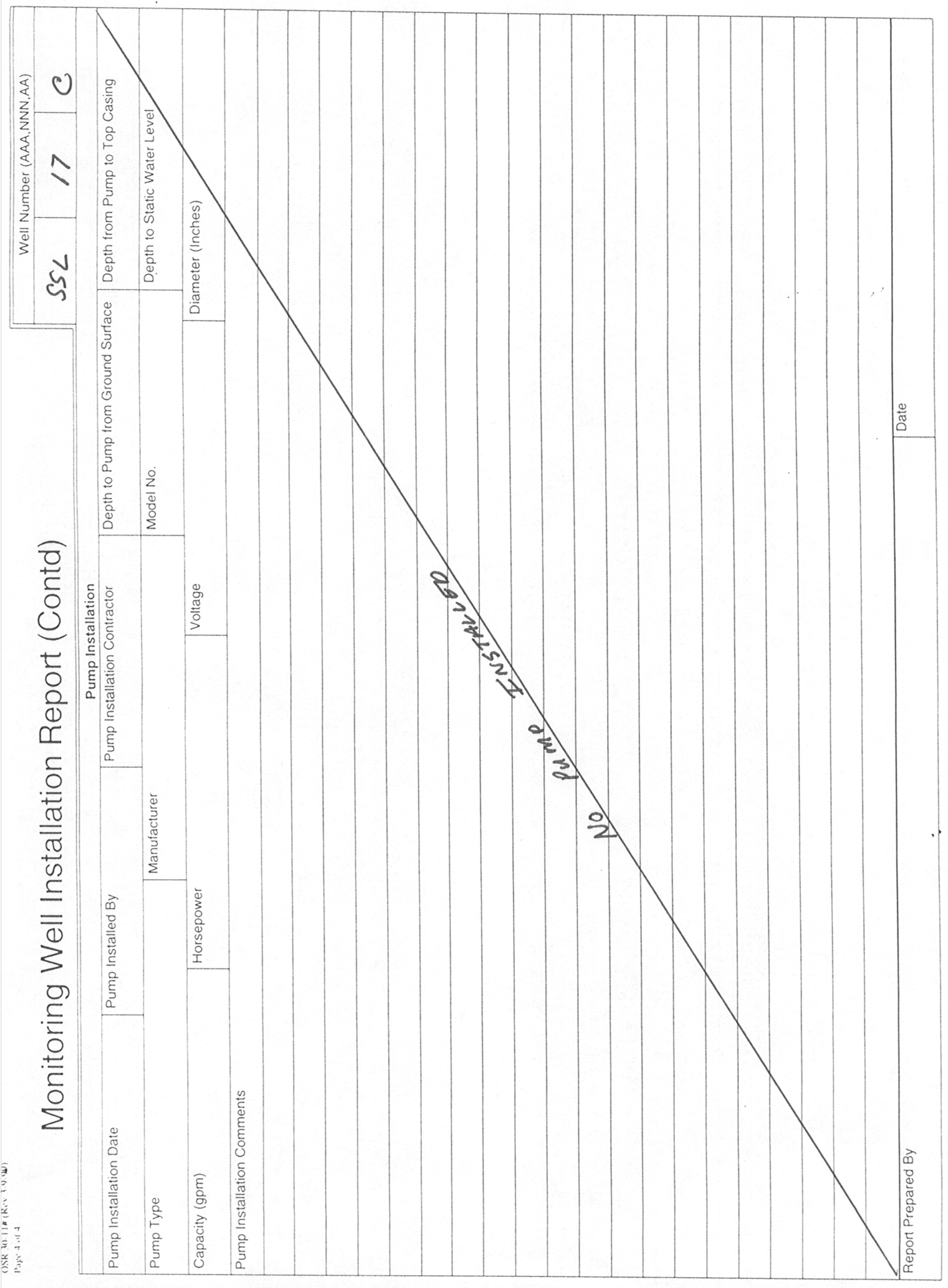




\section{Monitoring Well Construction Diagram}

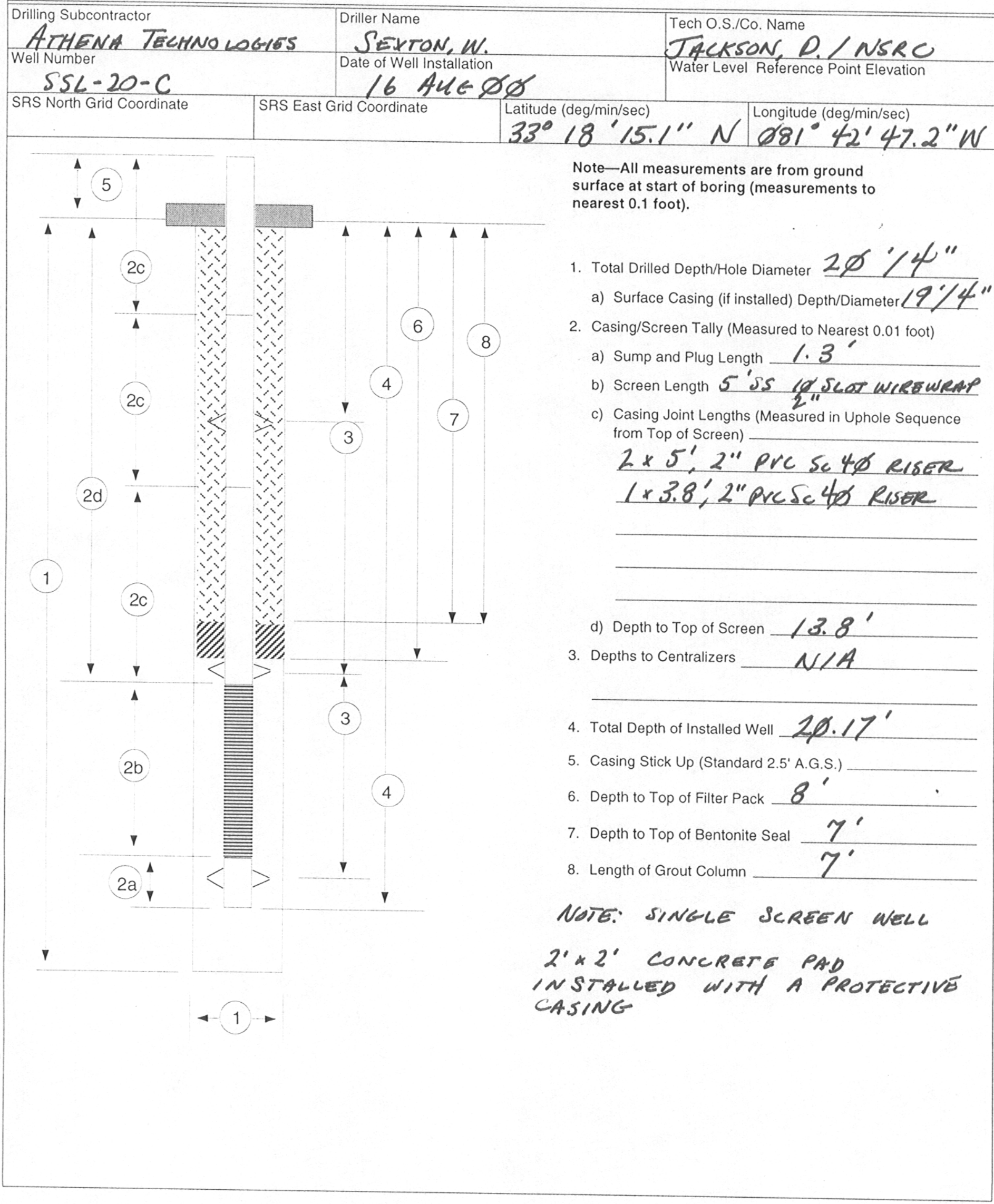




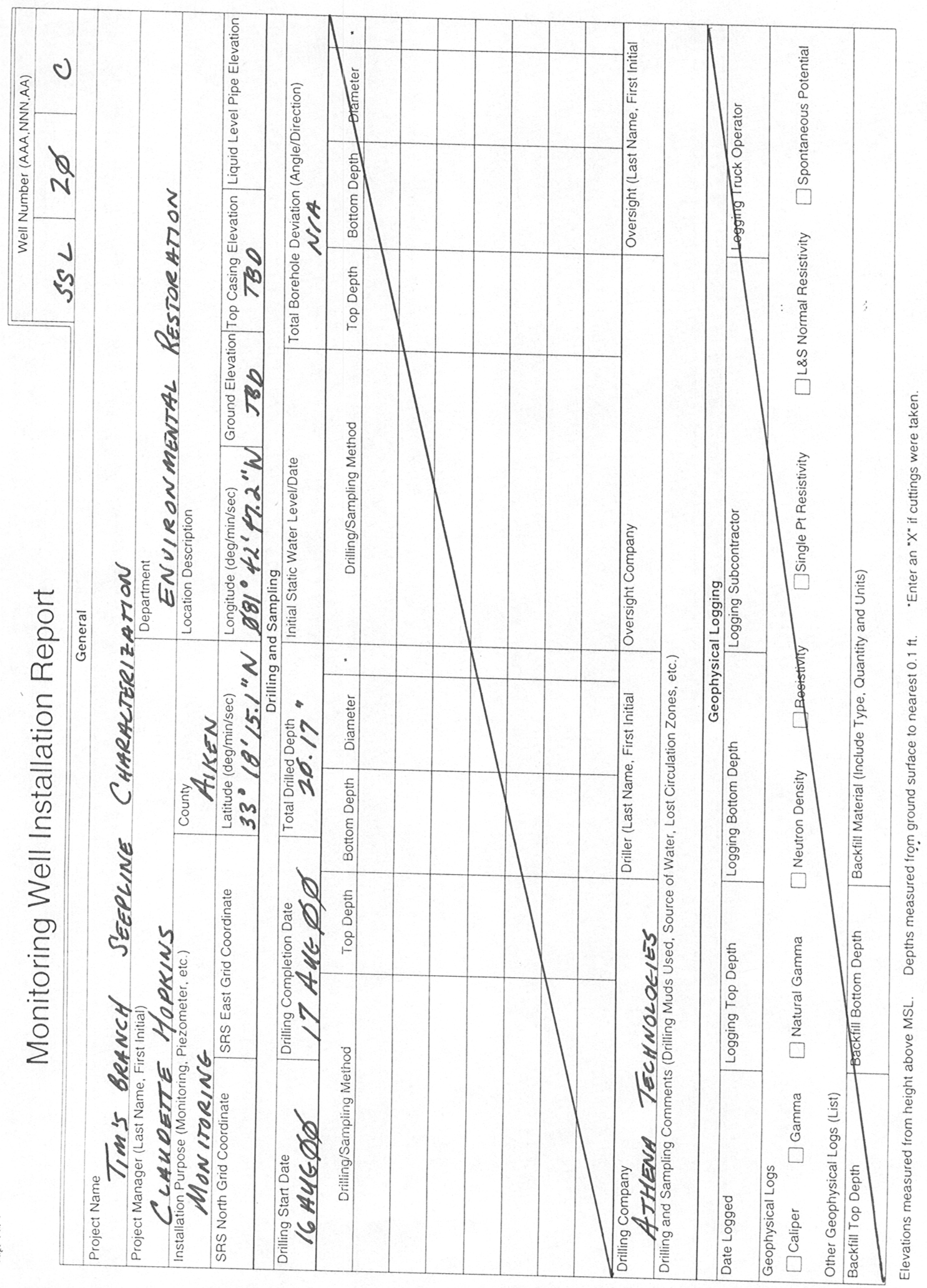




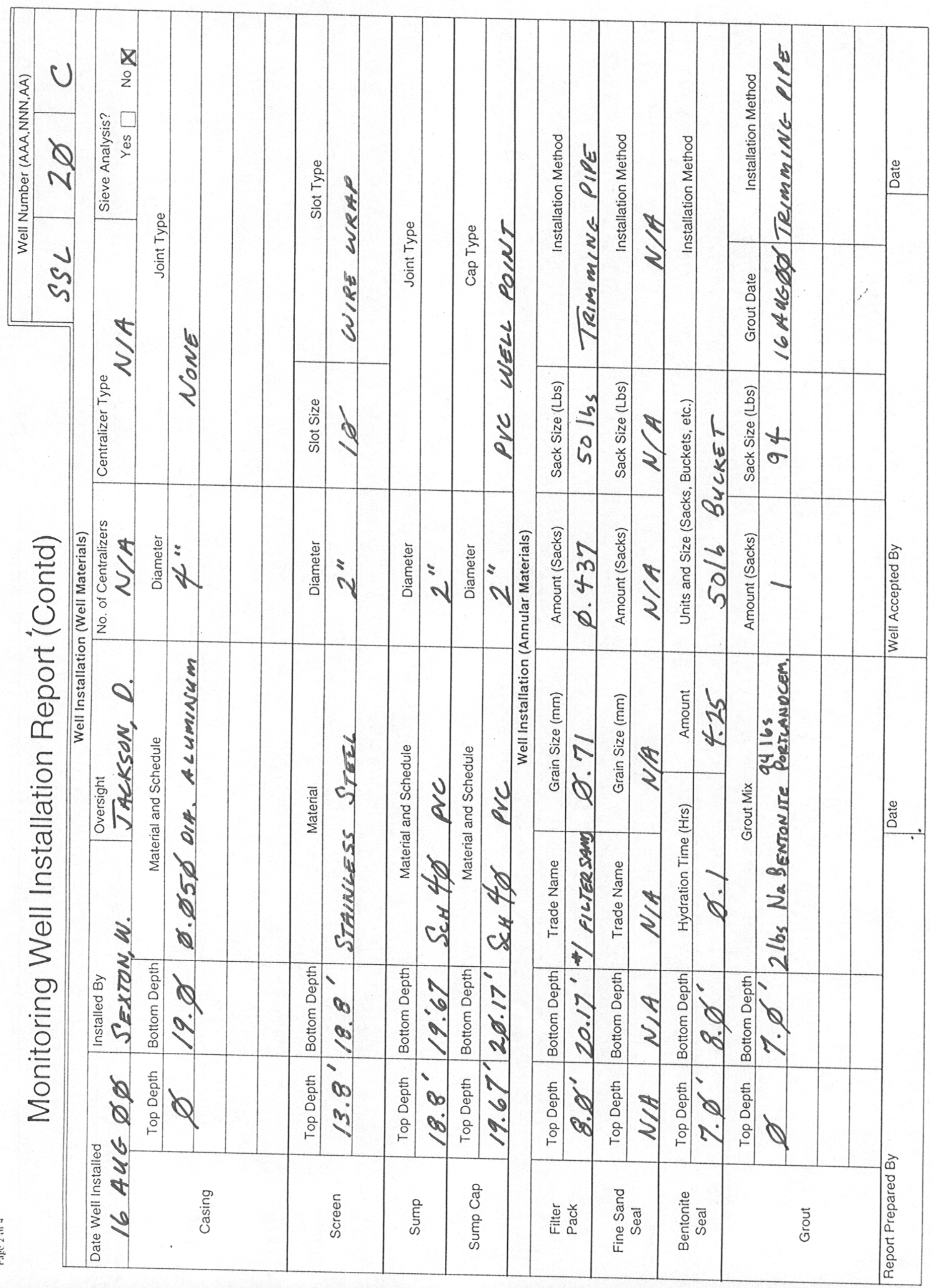




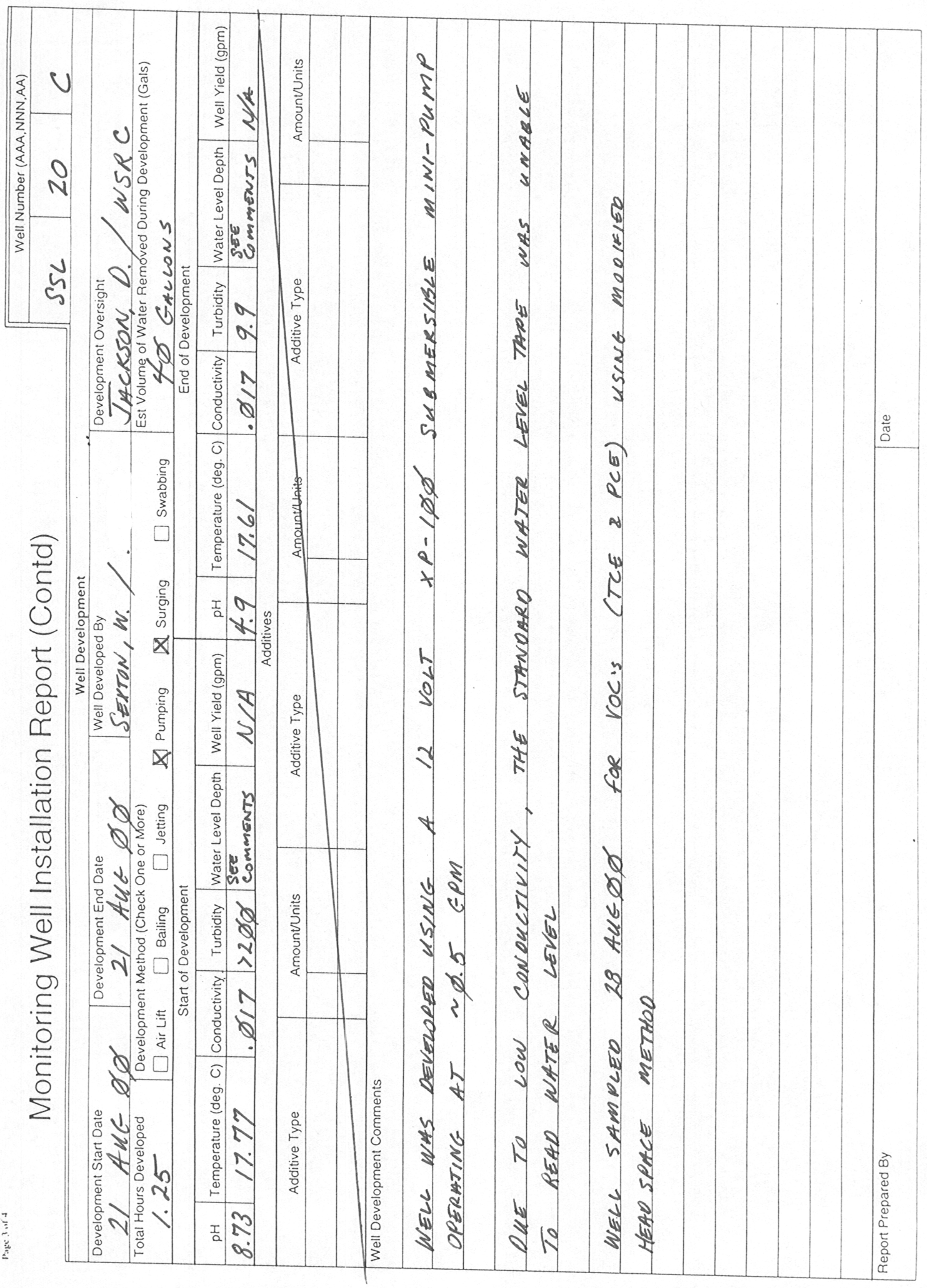




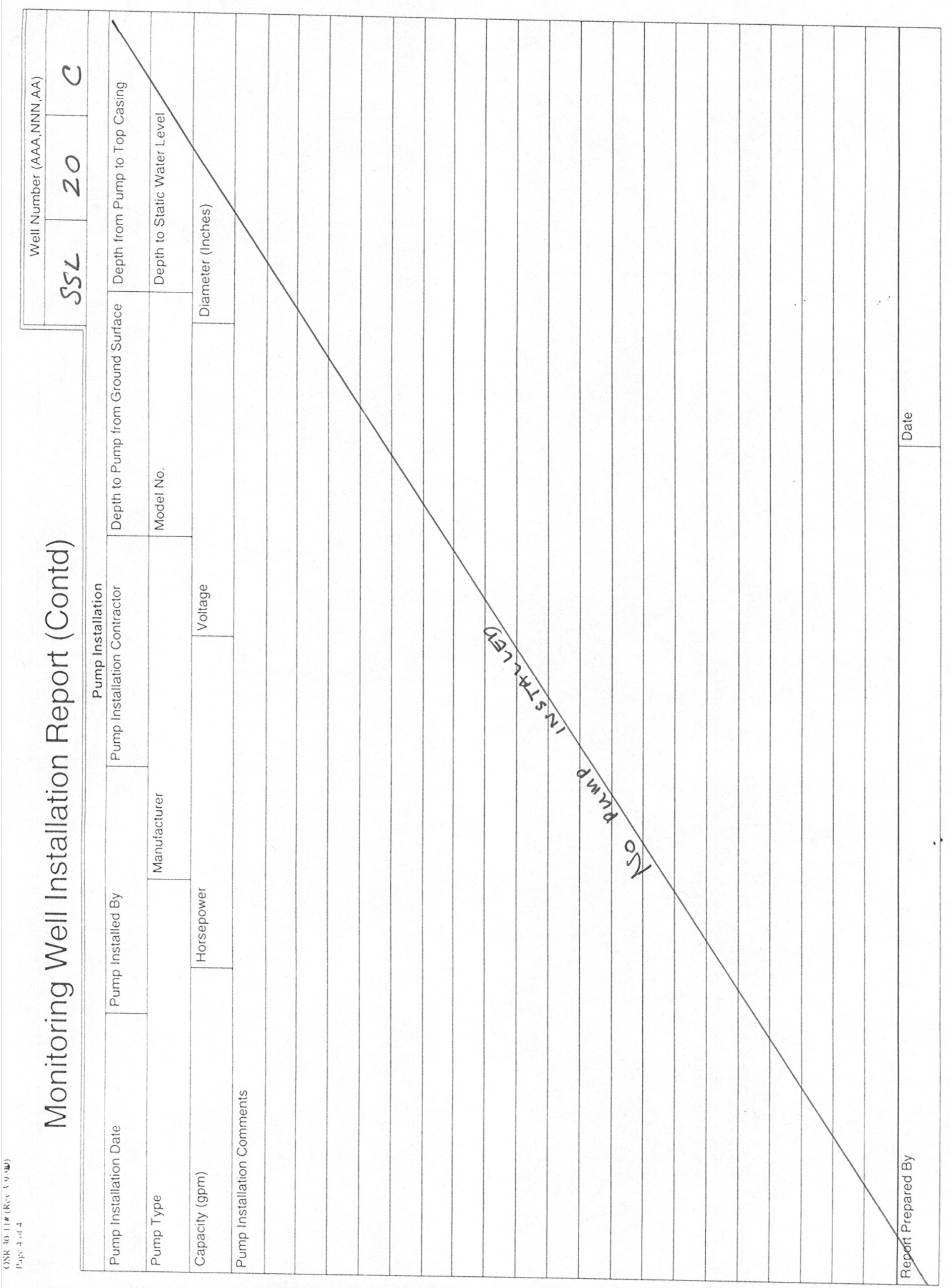




\section{Monitoring Well Construction Diagram}

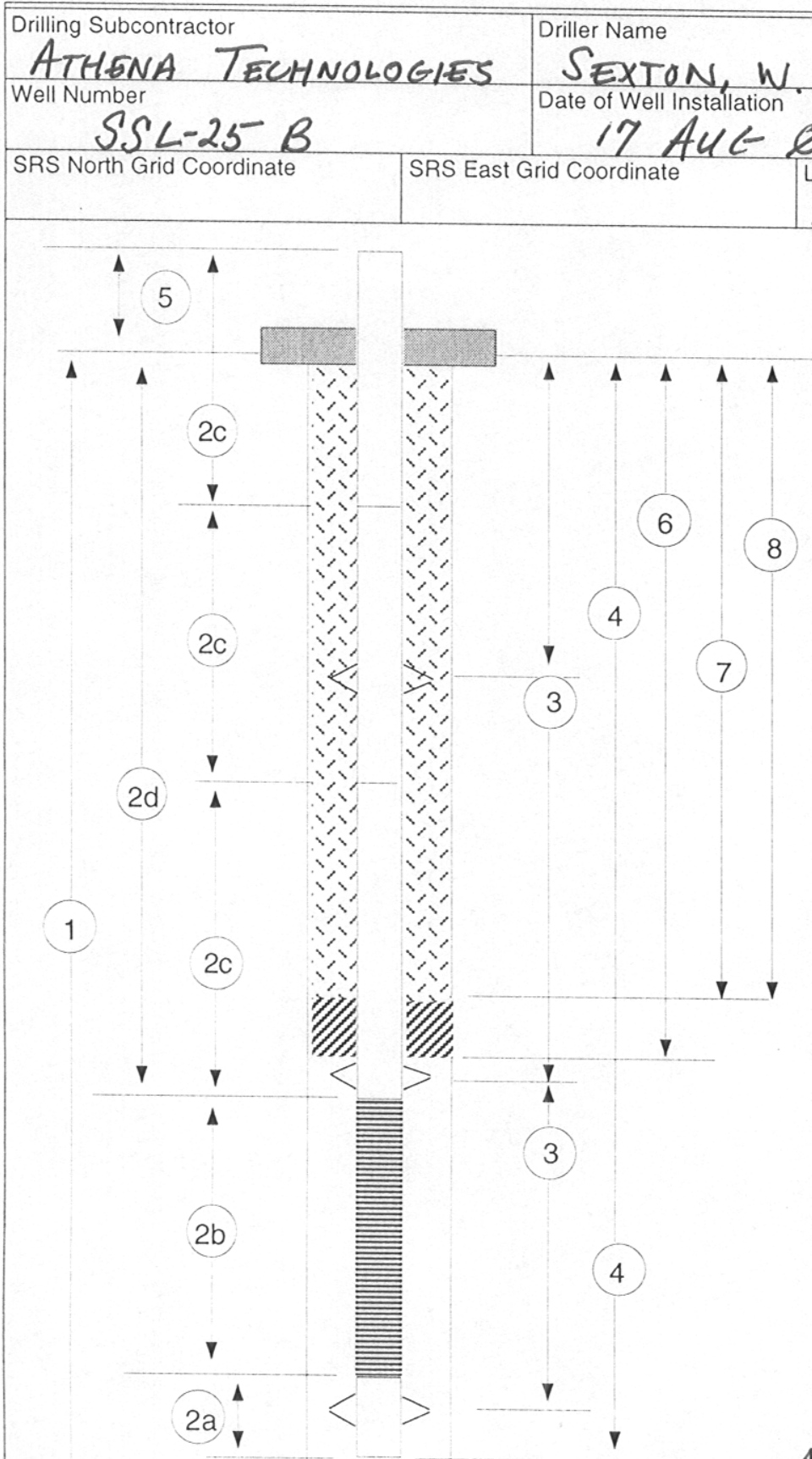

NOTES: WELL IS A MULTILEVEL MONITORING WELL INSTALLED IN A COMMON BOREALLE WITH SSL-2SC

$2^{\prime} \times 2^{\prime}$ CONCRETE PAD INSTHLLED

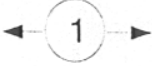
WITH PROTECTIVE CASING

ACLESS TO WELL SCREEN THROUGH $5 / 8$ " POLY ETHYLENE TUBINE

Note-All measurements are from ground surface at start of boring (measurements to

1. Total Drilled Depth/Hole Diameter 15.75 " $/ 4 "$

a) Surface Casing (if installed) Depth/Diameter $151 / \mathrm{f}^{\prime \prime}$

2. Casing/Screen Tally (Measured to Nearest 0,01 foot)

a) Sump and Plug Length $\varnothing .5$

b) Screen Length $2^{\prime} 2$ "SS STRATA SAMPLER

c) Casing Joint Lengths (Measured in Uphole Sequence from Top of Screen)

$1 \times 5,2 " \mathrm{SCH} 40$ PVC RISER $1 \times 5 ; 2 " S C N 4 \%$ PVC SLOTTED SCREEN $1 \times 3.25 .2^{\prime \prime S C H}$ HO PVC RISER

d) Depth to Top of Screen 13.25

3. Depths to Centralizers $N / A$

4. Total Depth of Installed Well $15.75^{\prime}$

5. Casing Stick Up (Standard 2.5' A.G.S.)

6. Depth to Top of Filter Pack 12,5

7. Depth to Top of Bentonite Seal $/ / .5^{\prime}$

8. Length of Grout Column _..N N/A 


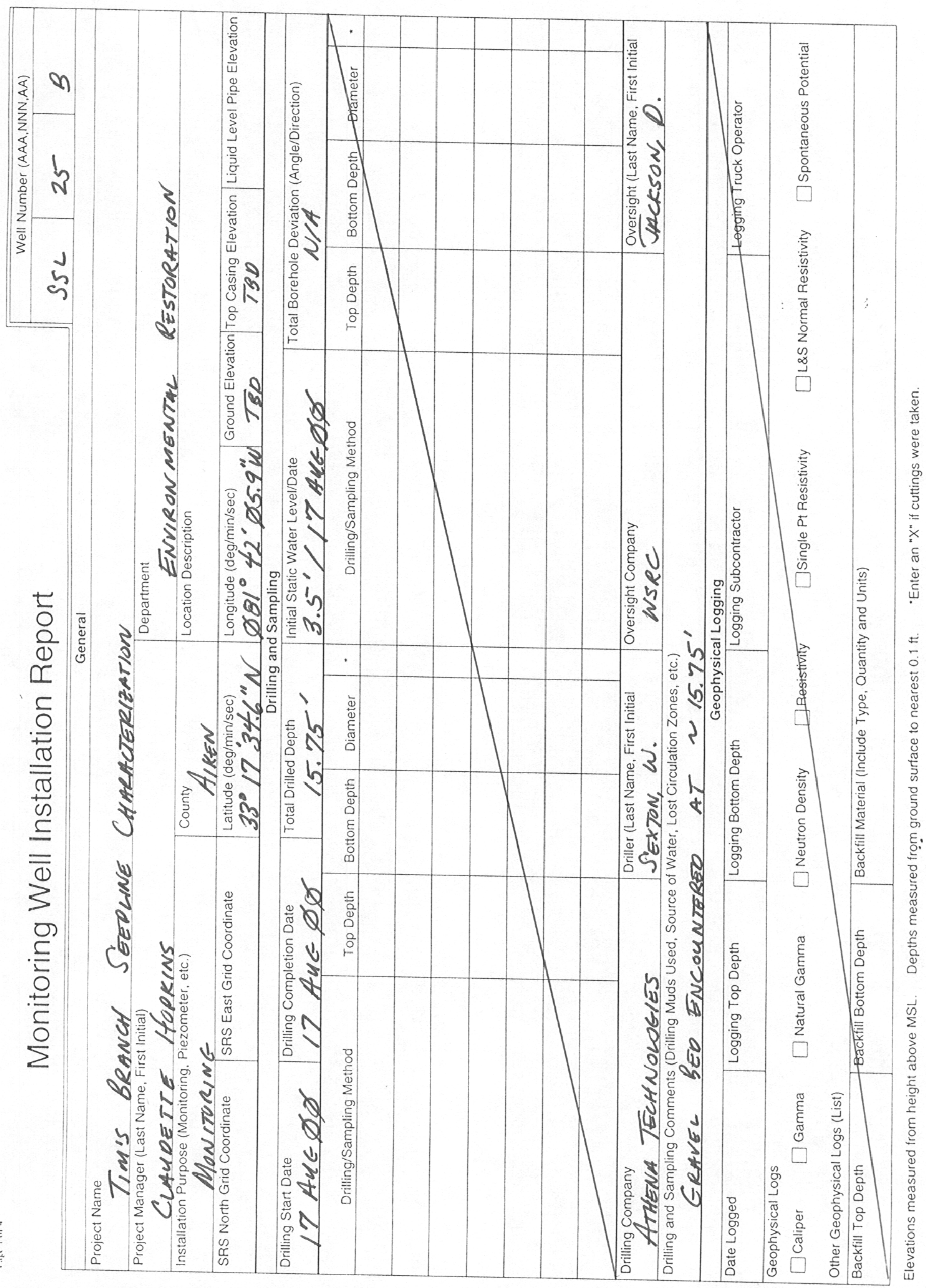




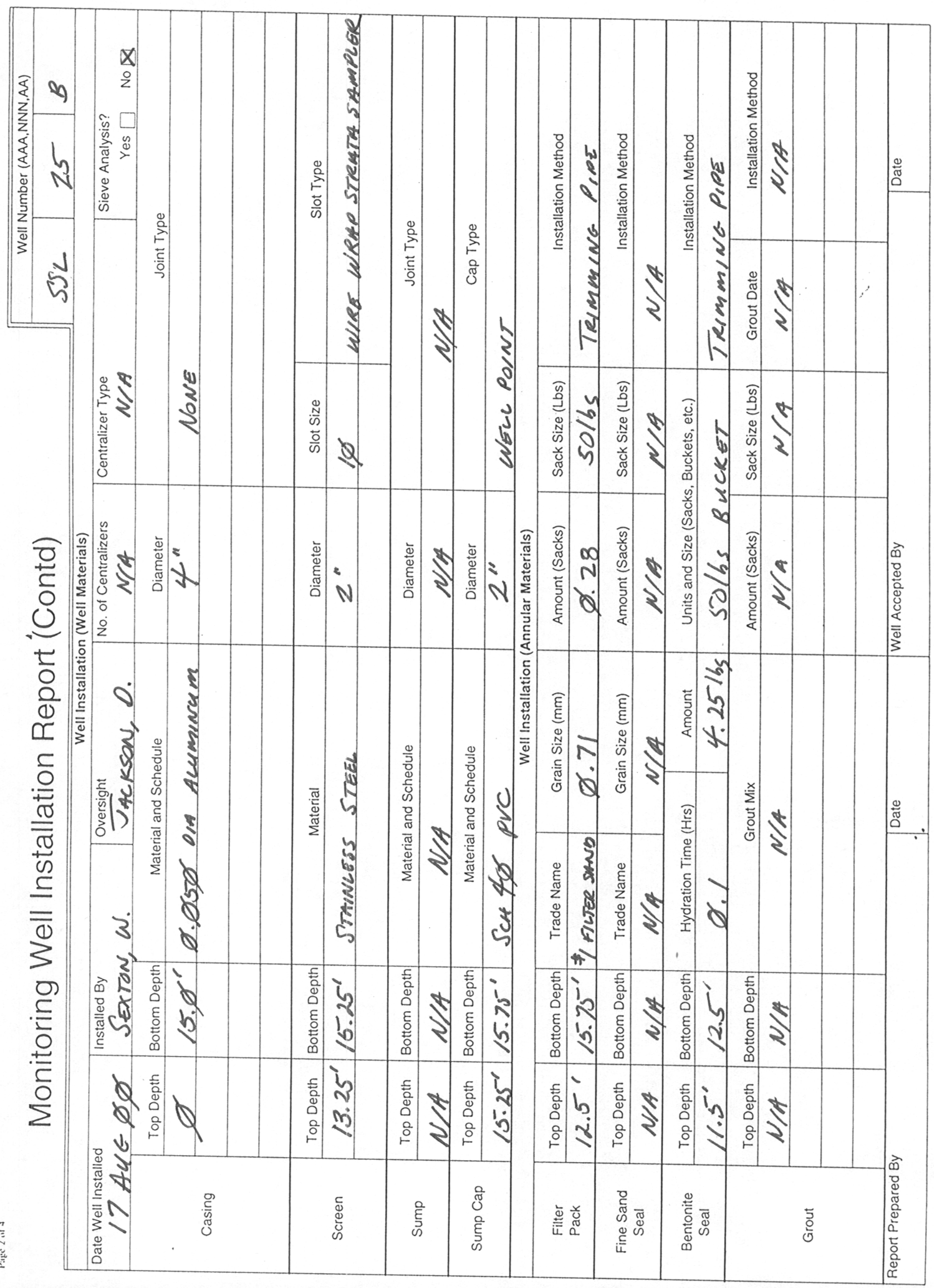




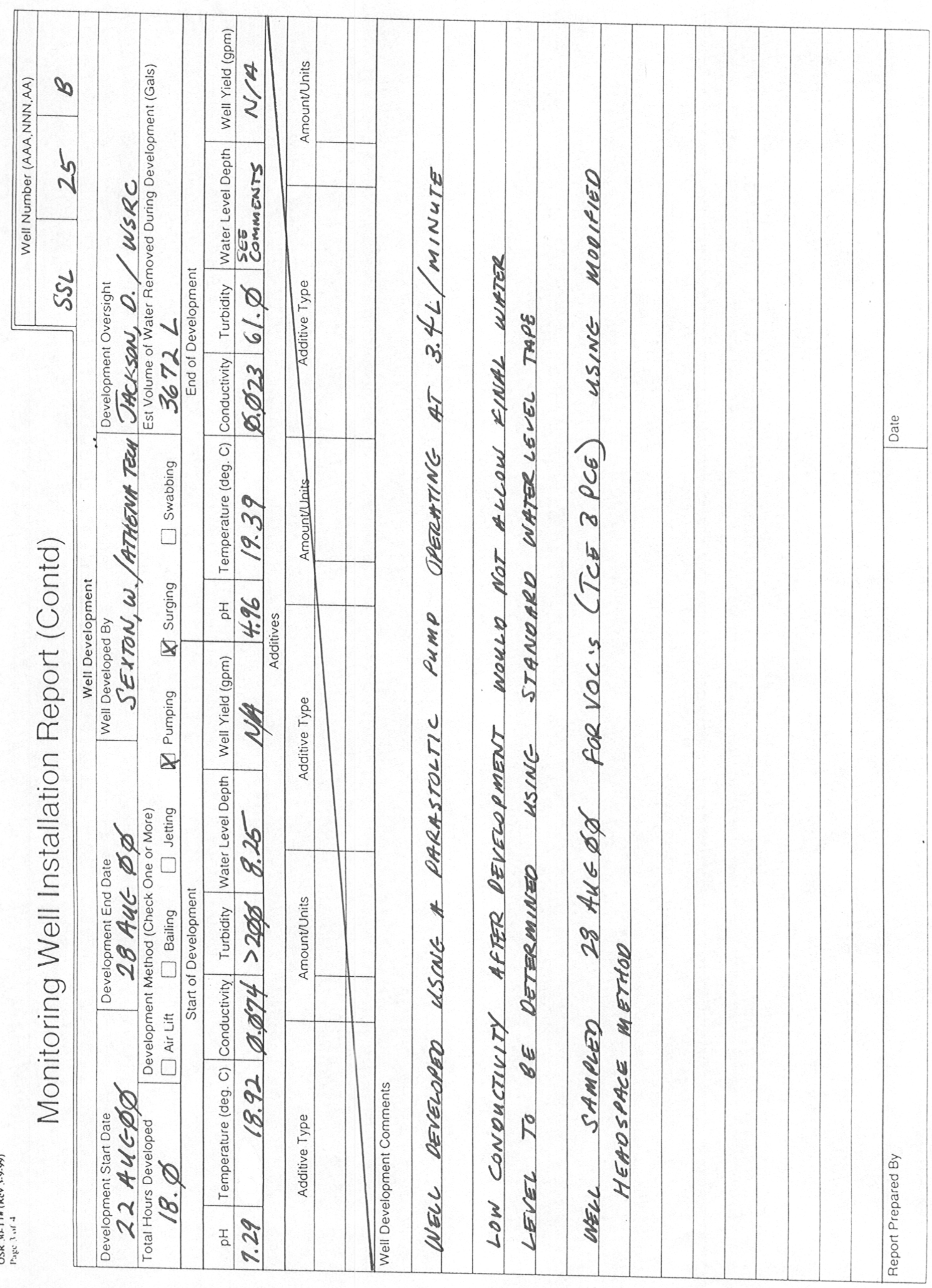




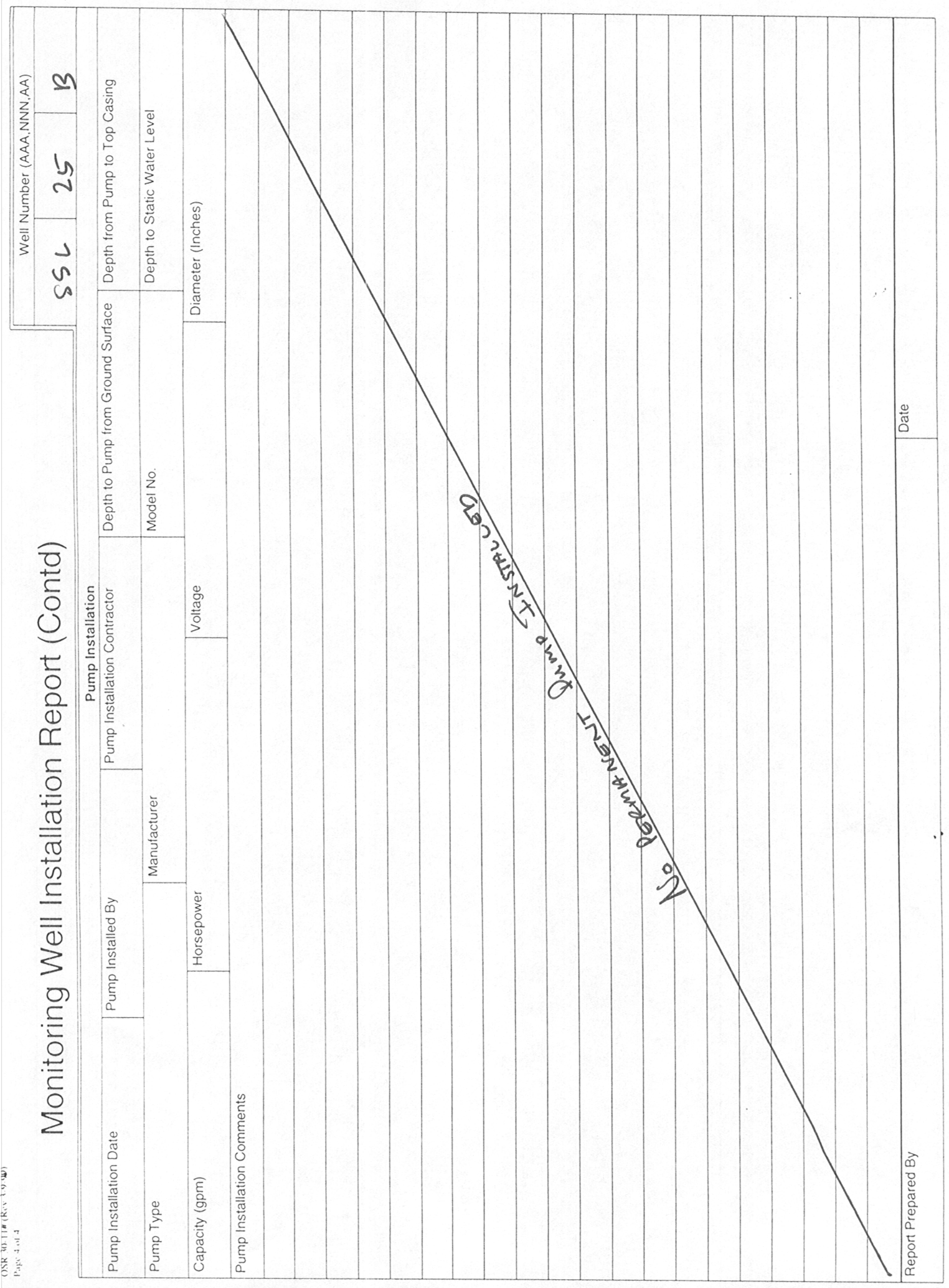




\section{Monitoring Well Construction Diagram}

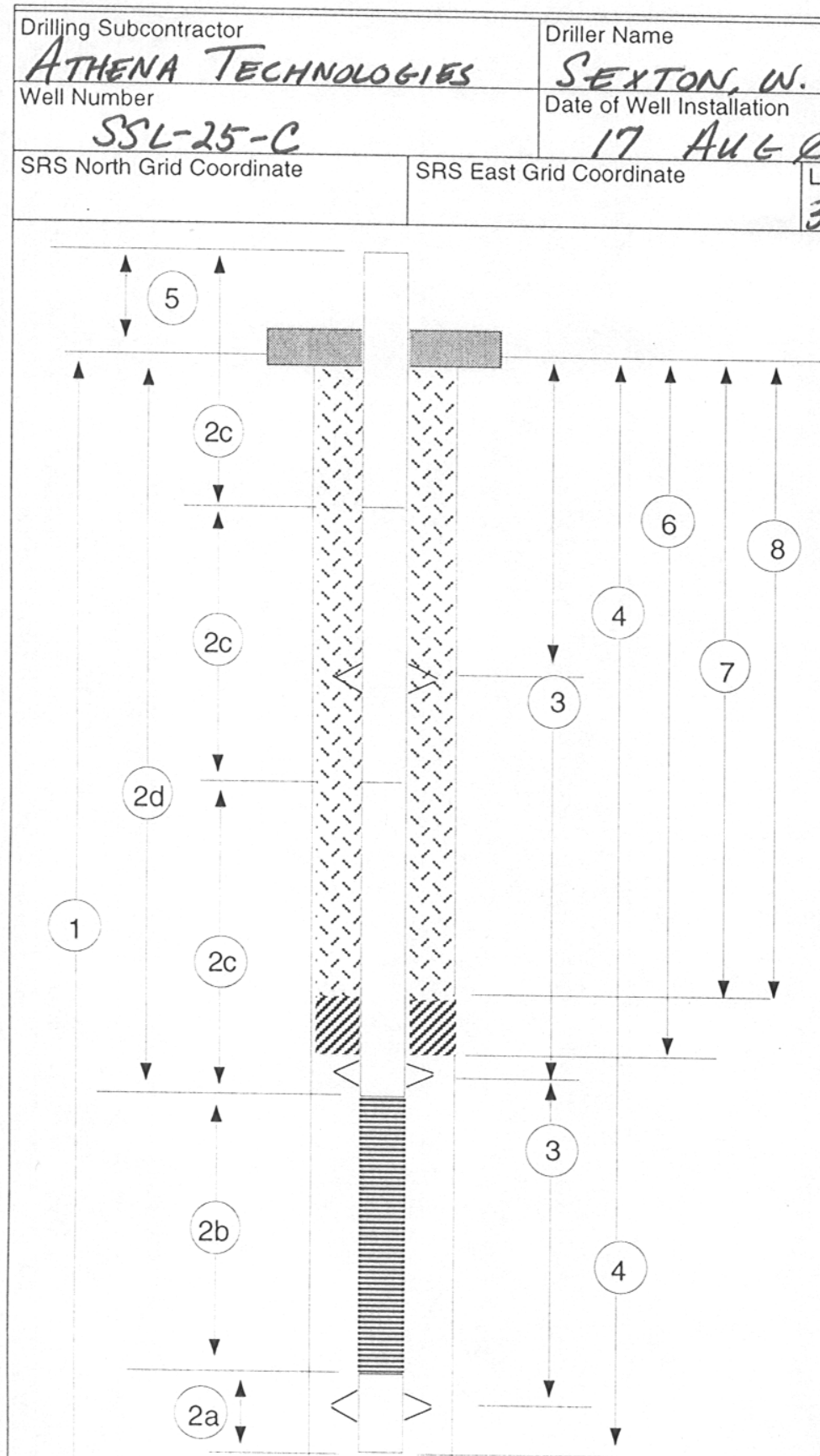

d) Depth to Top of Screen $-3.25^{\prime}$

3. Depths to Centralizers $N / A$

4. Total Depth of Installed Well

$15.75^{\circ}$

5. Casing Stick Up (Standard 2.5' A.G.S.)

6. Depth to Top of Filter Pack $3 . \varnothing^{\prime}$

7. Depth to Top of Bentonite Seal 2. $\varnothing^{\prime \prime}$

8. Length of Grout Column $2 . \varnothing$

NOTES: WELL IS A MULTLEVEL MONITORING WELL INSTALLED IN A COMMON BORE HOLE WITH SSL-25B

$2^{\prime} \times 2^{\prime}$ CONCRETE PAD INSTALLED WITH A PROTECTIVE CASINE

ACLESS TO WEL SCREEN THROUGH 5/8" DIAMETER POLY ETHYLENE TUBING 


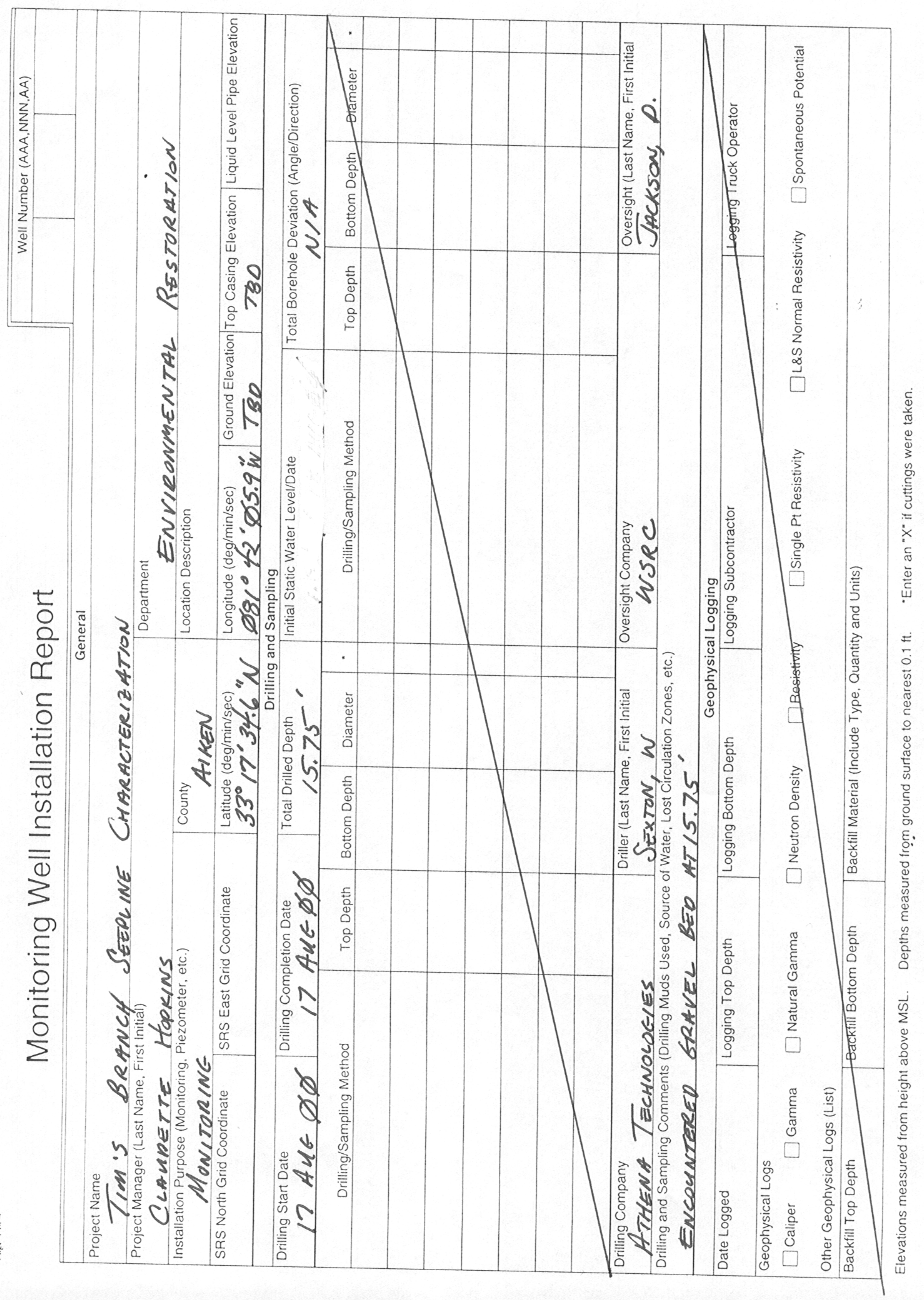




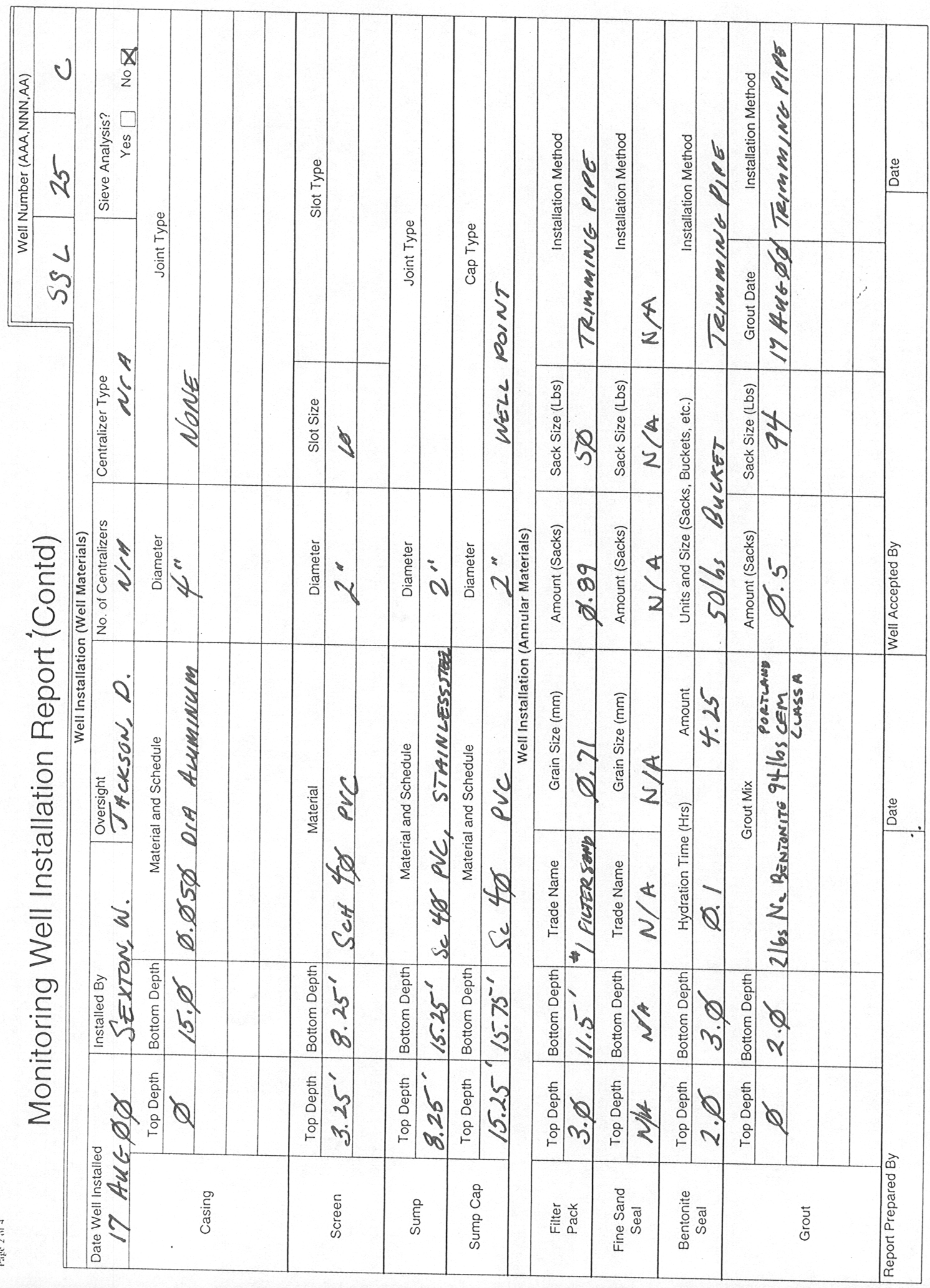




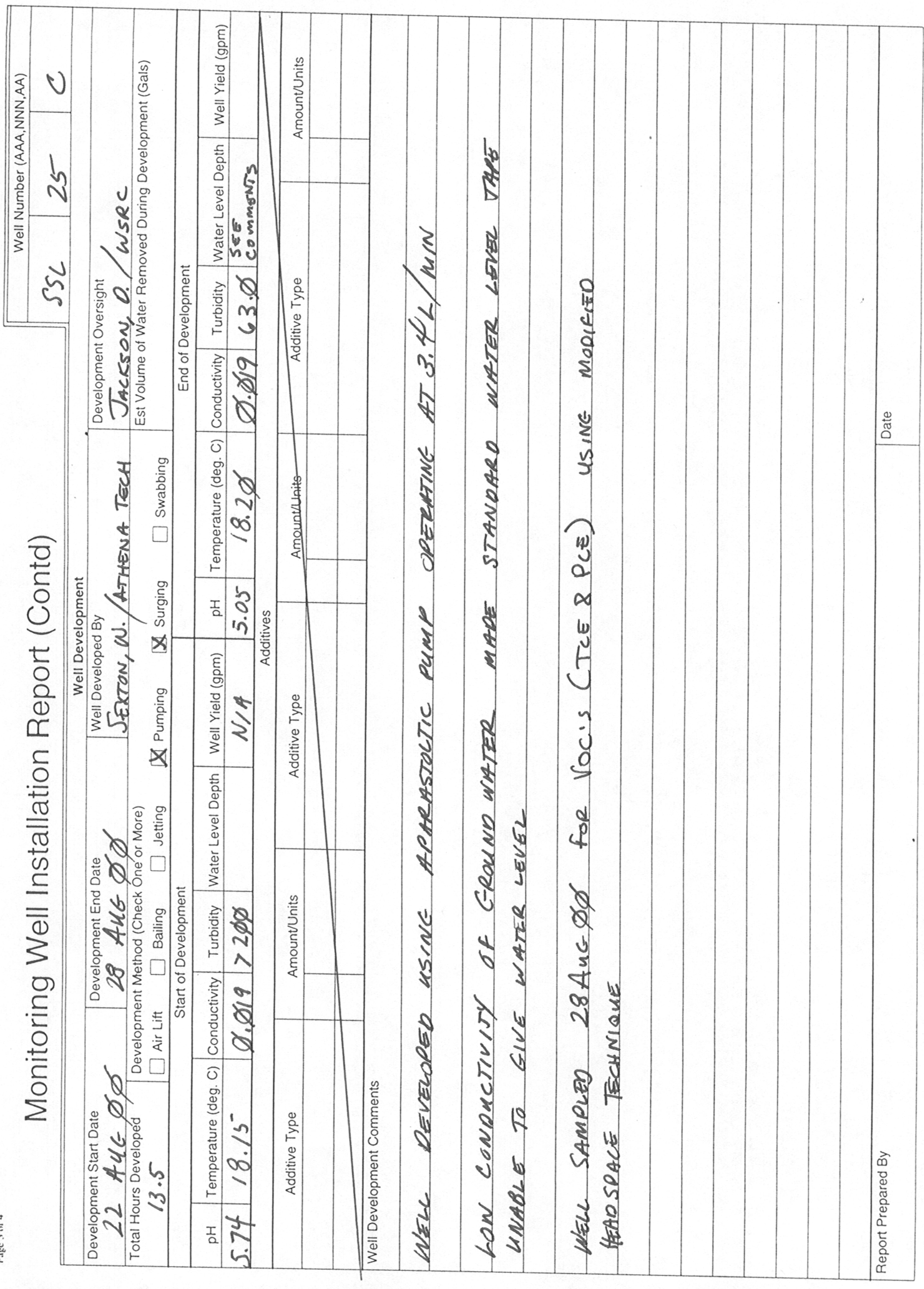




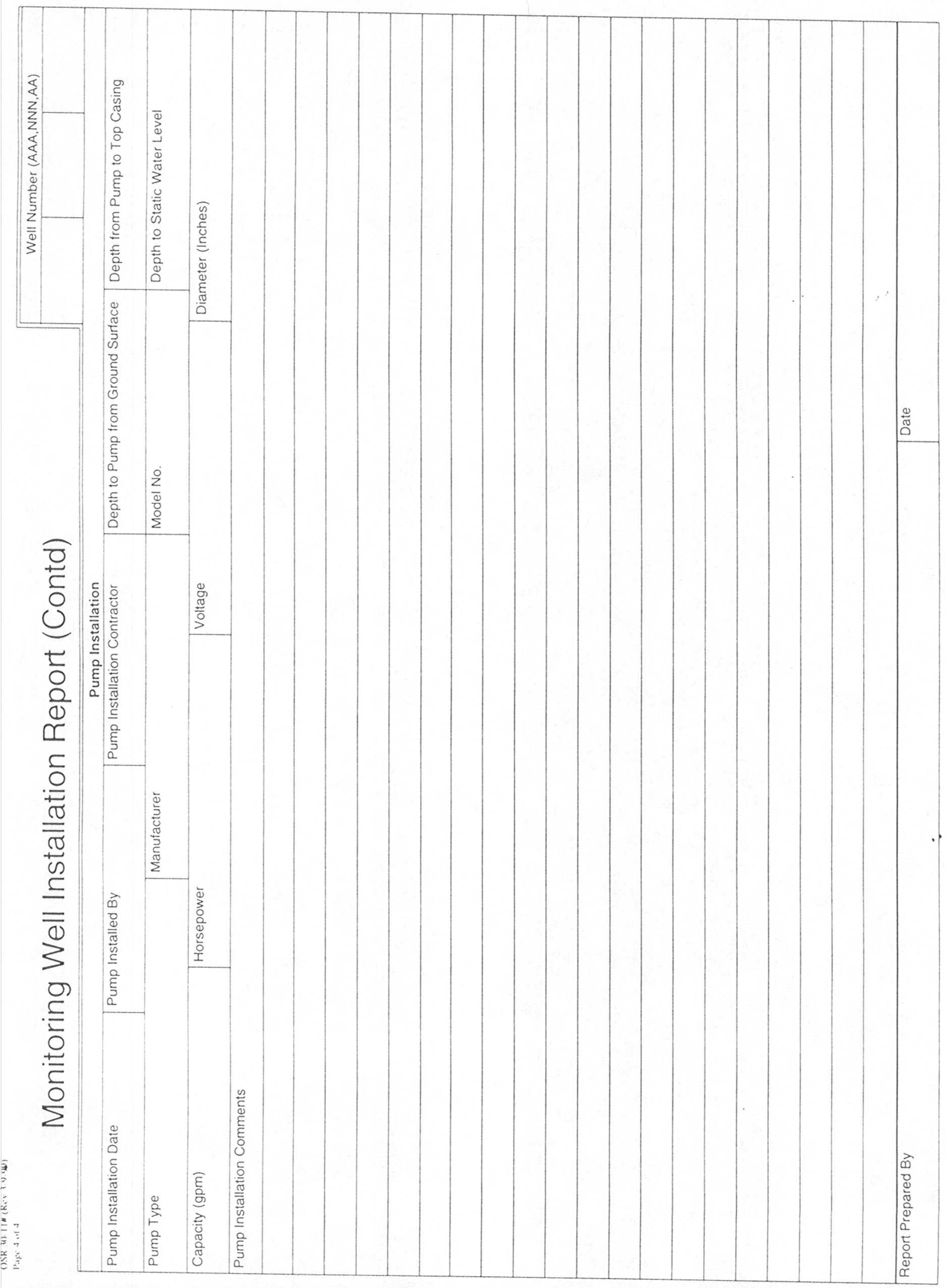




\section{Monitoring Well Construction Diagram}

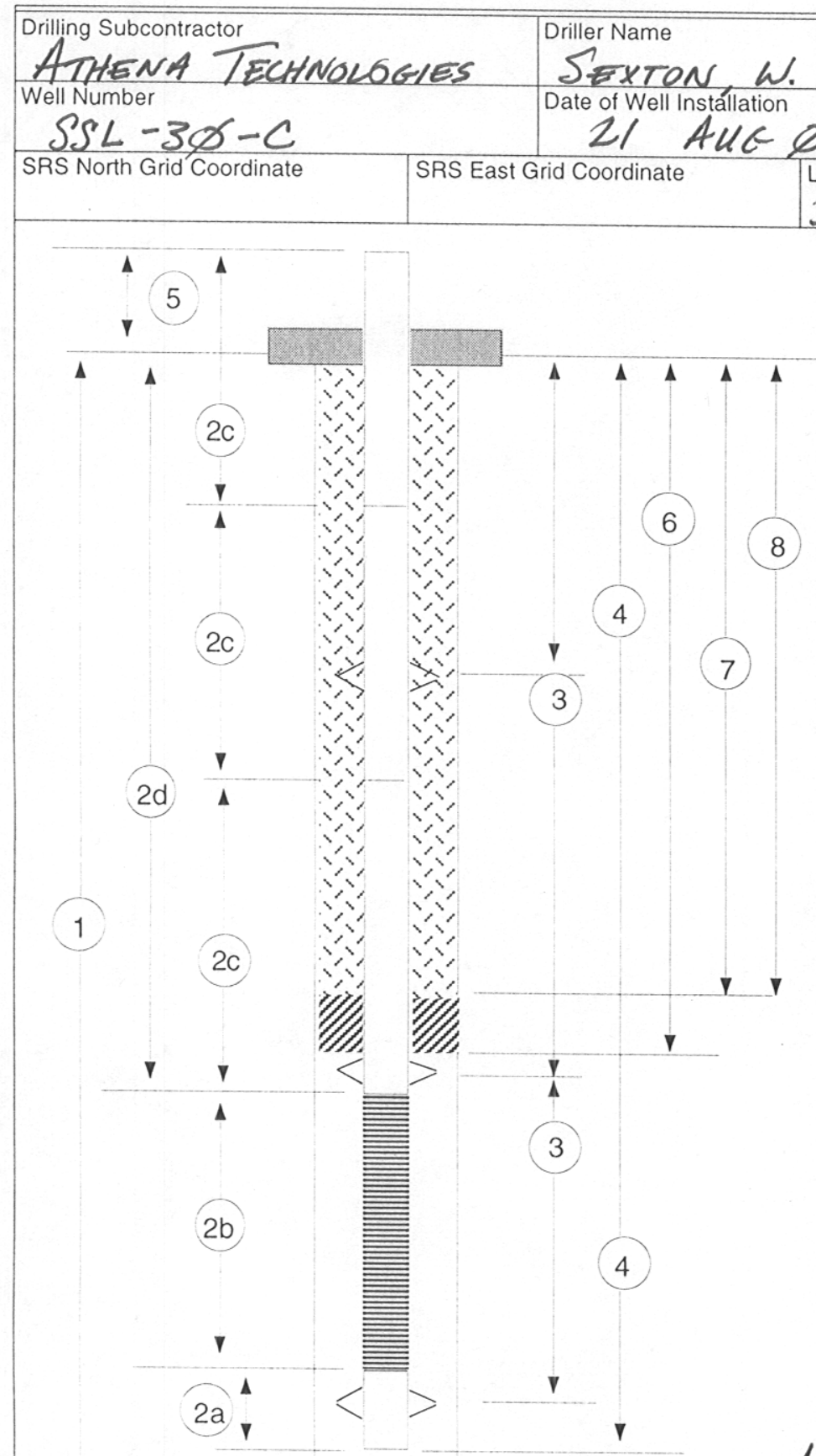

Notes: SINGLE SCREen well 


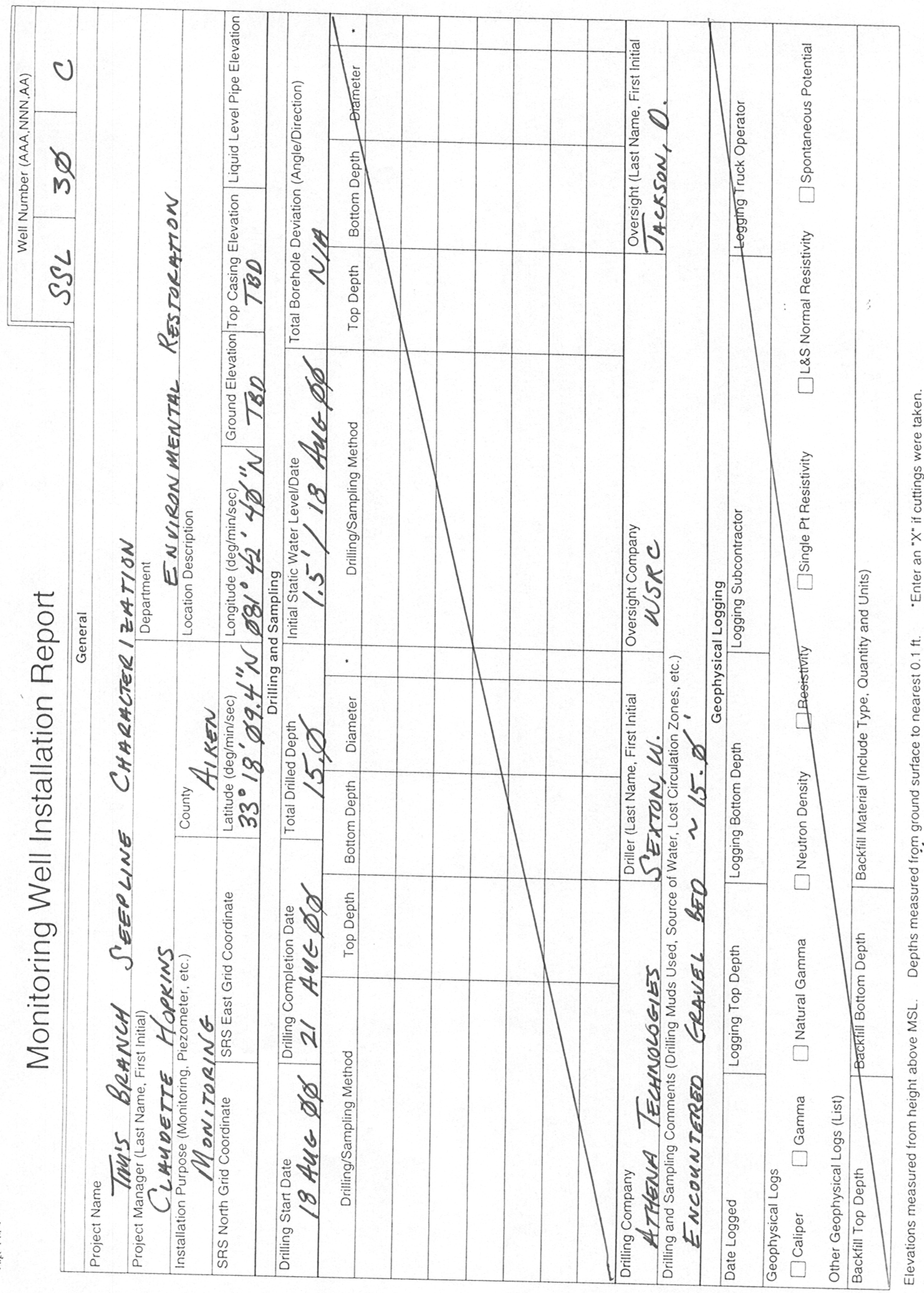




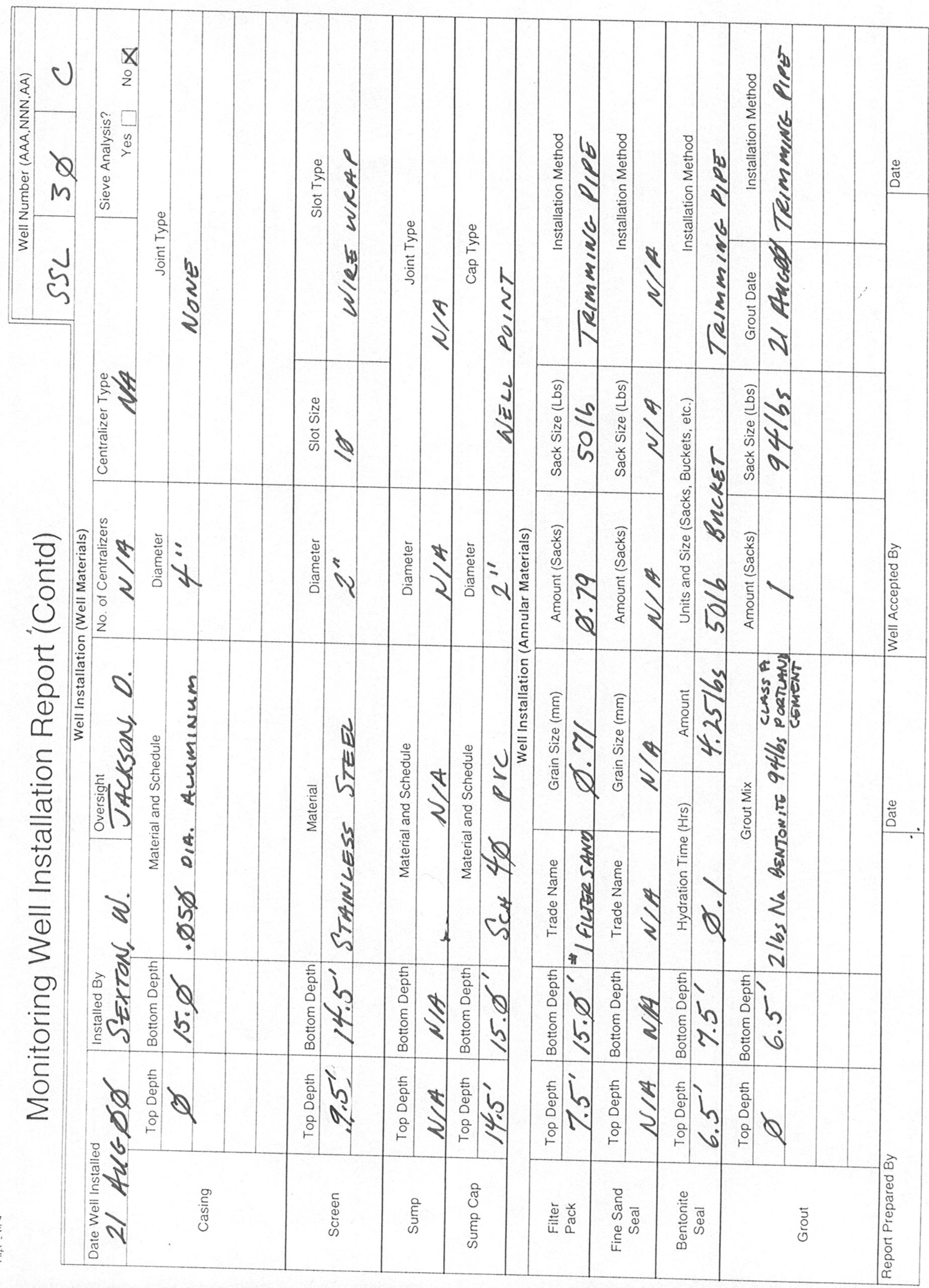




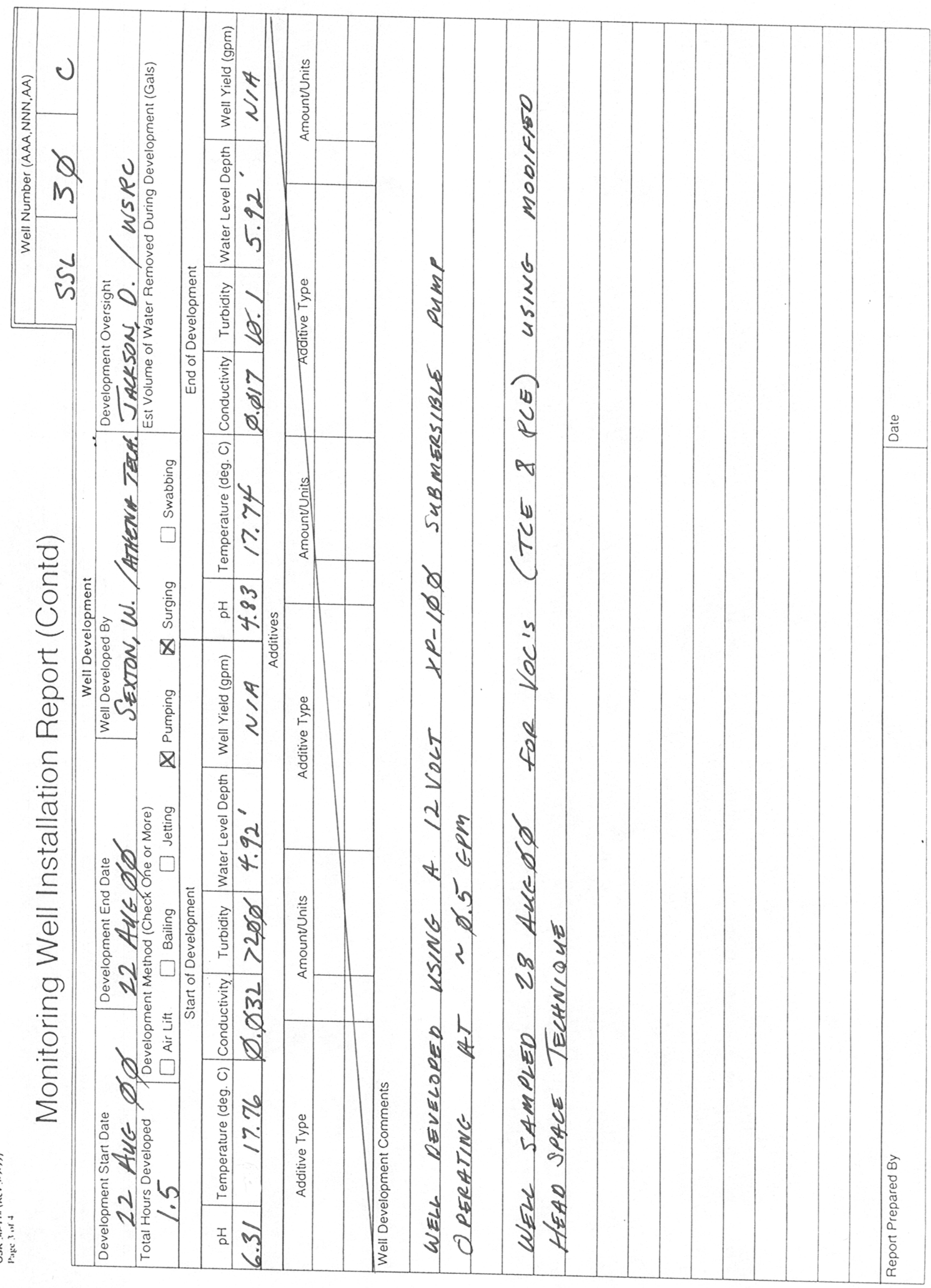




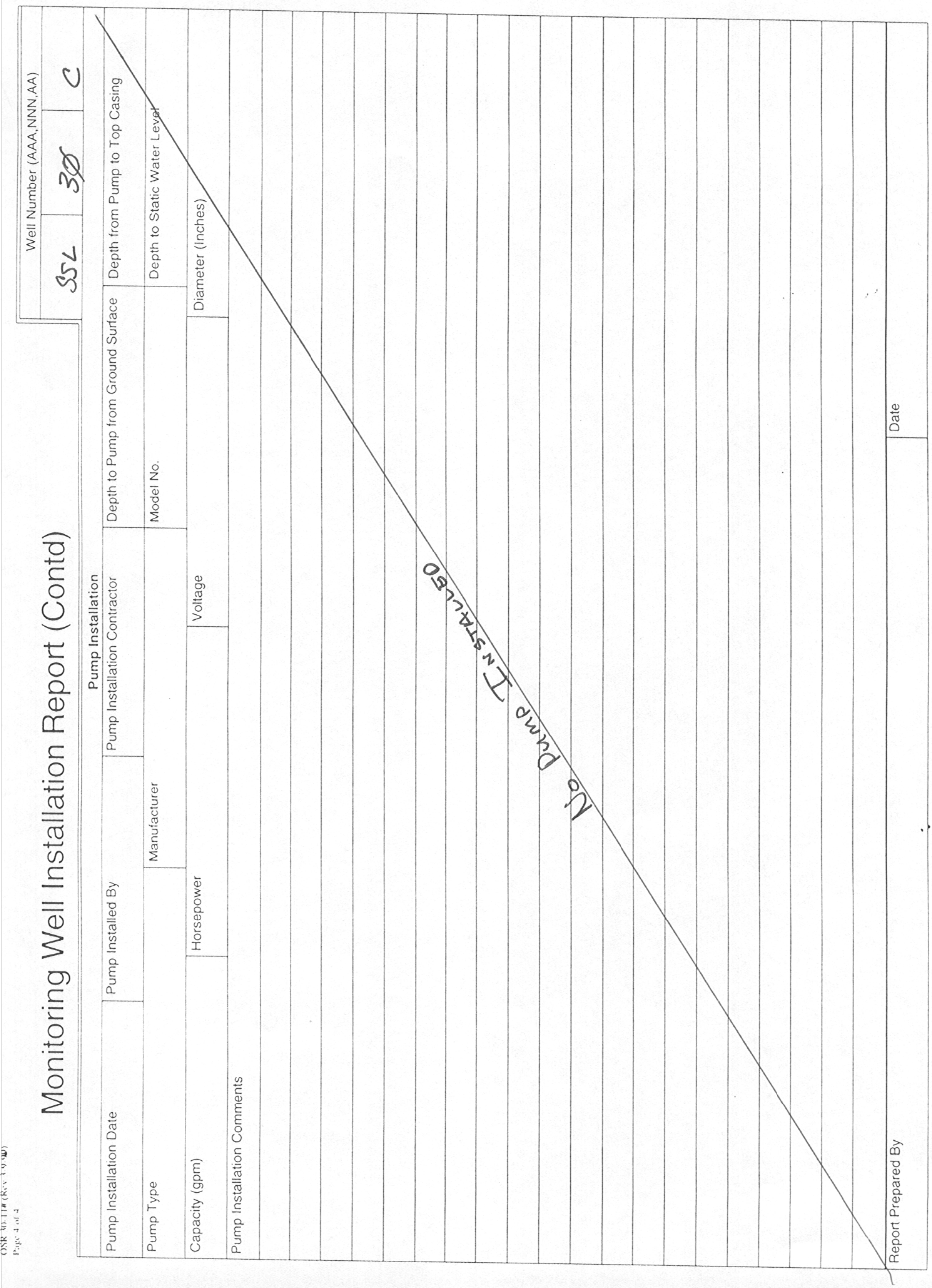




\section{Estimate of Mass-Flux to Hyporheic Zone Near Road 2}


OSR $25-10(\operatorname{Rev} 6-18-92)$

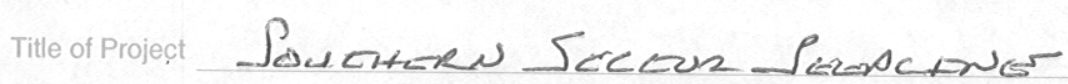

Subject

Computer

Project No. WSRC- TRR-2000 - $02 x_{2} 72$

Works

$12 / 2 / 00$

Date

Sheet No. $1 / 3$

Estomatw ther MAss fiux de TEE Aus PCE

Entarrana tur itgPoritefe Zune Nabr SRS

ROAD 2 Ana TIn's Brancut:

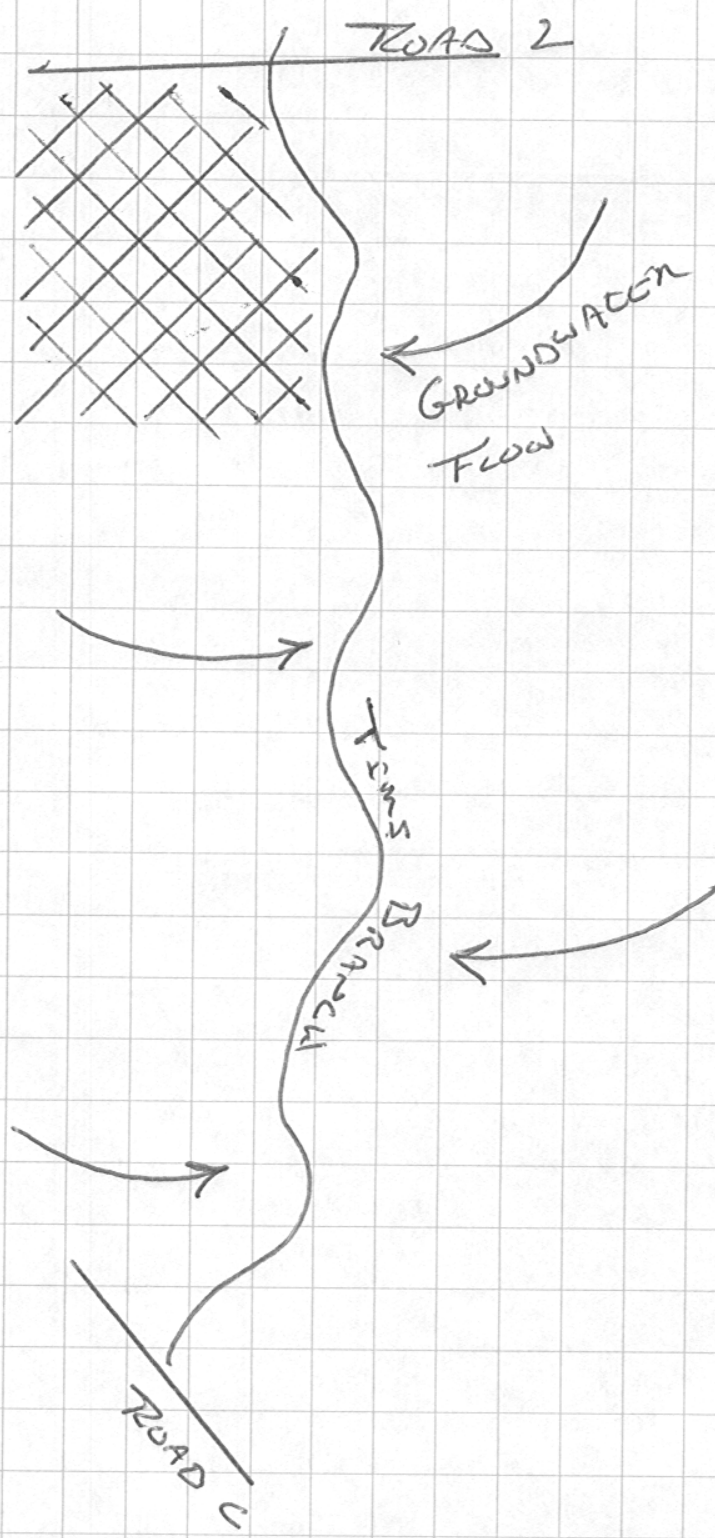

Z3rsmpan Constonons:

TOAS $2 \quad 2.35 \mathrm{FC}^{3} / \mathrm{s}$

TuRs C $5.5 / \mathrm{fe}^{-3} / \mathrm{s}$

LENGET ISEtWhéN

SEACNUNS $\quad 2.34$

WDEEH OF PLUME 2ADCDS FE

Nominal Concendrataonts:

TCE $25 \mathrm{ug} / \mathrm{l}$
PCE $10 \times \mathrm{ug} / \mathrm{l}$

MAss FuX $=\Delta C$

whiner Q Fs the Avarage Brasetrow Across Puner Wnatu And C Is titw Nomfnar Concentaration.

Not to SCALE

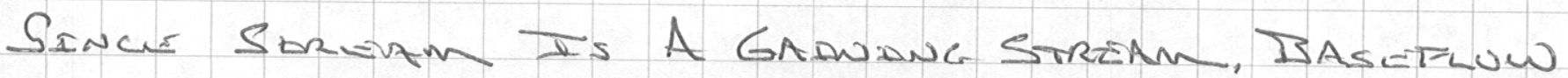

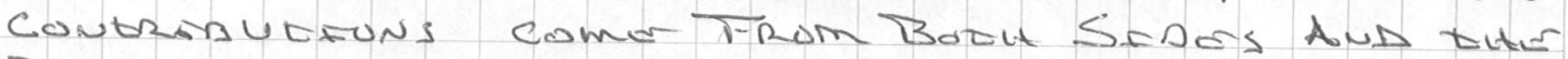
Poredow Assucantras witu MAss Flux Is 
OSR 25-10 (Rev 6-18-92)

ENGINEERING COMPUTATION SHEET

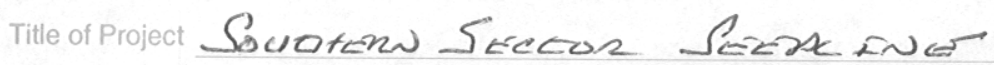
Project No. aisRc-TR-2ux-0at/72

Subject Works

Computer D. JACnses

Date $12 / 12 / 00$

Sheet No. 2/3

MALT tLE TUDR BASEFLOW.

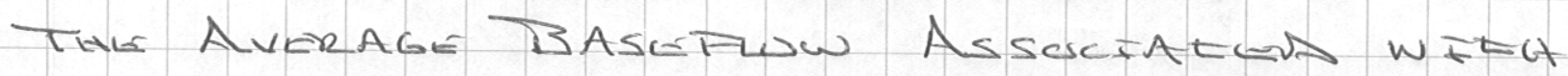

the Plume Ia Determines tha Assumang

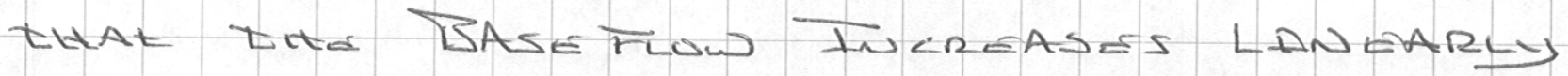

Bertwelad RoAs 2 Aw Rond C. Usong

Proportans the mascflow Ate Any

Distancer Is Grien Bu

$$
Q_{x}=Q_{\text {ROAD2 }}+\left(\frac{x}{2.34 \mathrm{mi}}\right)\left(Q_{\text {ROADC}}-Q_{\text {ROADZ }}\right)
$$

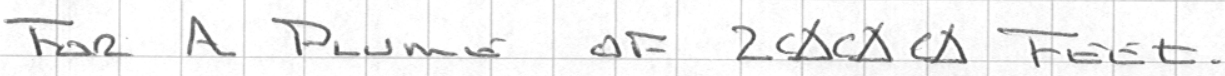

$$
\begin{aligned}
\theta_{2000} & =2.35 \mathrm{ft}^{3} / \mathrm{s}+\left(\frac{2000 / 5280}{2.34}\right)(5.51-2.35)^{\mathrm{ft} / \mathrm{s}} \\
& =2.86 \mathrm{ft}^{3} / \mathrm{s}
\end{aligned}
$$

Ther Average graundwaren teux Is

$$
\begin{aligned}
\bar{Q} & =\frac{Q_{2000}+Q_{\text {ROAD }}}{2} \\
& =\frac{(2.86+2.35) \mathrm{ft}^{3} / \mathrm{s}}{2} \\
& =2.6 \mathrm{ft} / \mathrm{s}
\end{aligned}
$$


OSR 25-10 (Rev 6-18-92)

ENGINEERING COMPUTATION SHEET

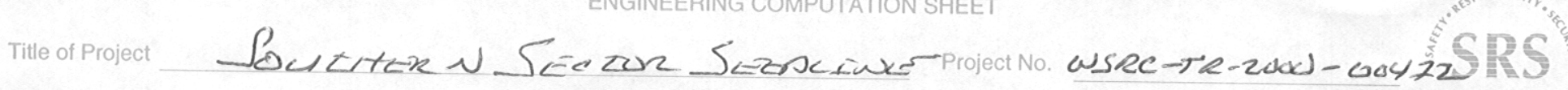

Subject Works Computer DITtoes on Date $12 / 12 / 00$ Sheet No. $-3 / 3$

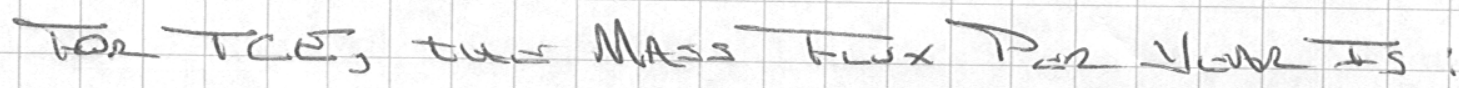

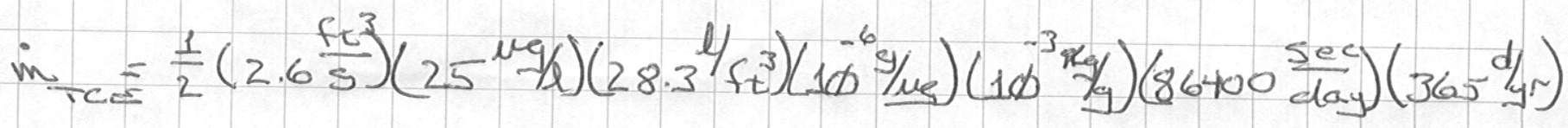

$$
\begin{aligned}
& =29 \mathrm{~kg} / \mathrm{ur} \text { or lo } 4 \text { pounds/yr }
\end{aligned}
$$

tor PCE, the Mass hex par habits:

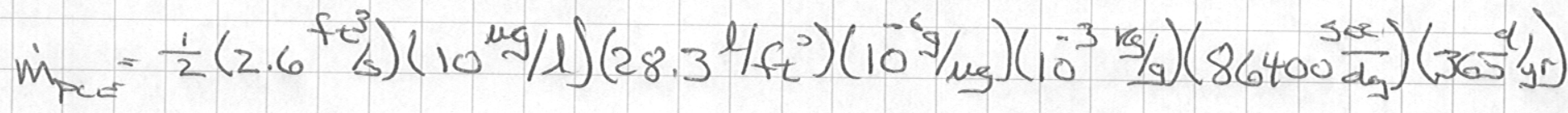

$$
\begin{aligned}
& =12 \mathrm{~kg} / \mathrm{yr} \text { or } 260 \text { Dandas/yr }
\end{aligned}
$$

